University of Rhode Island

DigitalCommons@URI

Open Access Dissertations

2015

\title{
Modeling Onsite Wastewater Treatment System Contaminants in Current and Climate Changing Conditions
}

Ivan Morales Parra

University of Rhode Island, ivanmorales.parra@gmail.com

Follow this and additional works at: https://digitalcommons.uri.edu/oa_diss

\section{Recommended Citation}

Morales Parra, Ivan, "Modeling Onsite Wastewater Treatment System Contaminants in Current and Climate Changing Conditions" (2015). Open Access Dissertations. Paper 376.

https://digitalcommons.uri.edu/oa_diss/376

This Dissertation is brought to you for free and open access by DigitalCommons@URI. It has been accepted for inclusion in Open Access Dissertations by an authorized administrator of DigitalCommons@URI. For more information, please contact digitalcommons-group@uri.edu. 
MODELING ONSITE WASTEWATER TREATMENT SYSTEM CONTAMINANTS IN CURRENT AND CLIMATE CHANGING CONDITIONS

BY

IVAN MORALES PARRA

A DISSERTATION SUBMITTED IN PARTIAL FULFILLMENT OF THE

REQUIREMENTS FOR THE DEGREE OF

DOCTOR OF PHISOLOPHY

IN

CIVIL AND ENVIRONMENTAL ENGINEERING

UNIVERSITY OF RHODE ISLAND 


\section{DOCTOR OF PHILOSOPHY DISSERTATION}

$\mathrm{OF}$

IVAN MORALES PARRA

APPROVED:

Dissertation Committee:

Major Professor

Thomas Boving

Vinka Oyanadel Craver

José Amador

Nasser H. Zawia

DEAN OF THE GRADUATE SCHOOL

UNIVERSITY OF RHODE ISLAND

2015 


\begin{abstract}
The use of onsite wastewater treatment system (OWTS) is a common practice in the U.S., especially in rural areas where the access to centralized wastewater treatment systems is limited. Onsite wastewater treatment systems include a soil treatment area or drainfield where contaminants are removed or attenuated. Ineffective OWTS are a source of microbial pathogens (bacteria and viruses), biological oxygen demand (BOD) and nutrients, which are among the major causes of contamination and water quality impairments in surface water in the U.S. The main objective of this research was to model the different chemical, physical processes, and removal mechanisms that influence the fate and transport of OWTS-derived contaminants using the HYDRUS 2D/3D software. In the first part of this study, segmented mesocosms $(n=3)$ packed with sand, sandy loam or clay loam soil were used to determine the effect of soil texture and depth on transport of two septic tank effluent (STE)-borne microbial pathogen surrogates green fluorescent protein-labeled E. coli (GFPE) and MS-2 coliphage - in soil treatment areas. In all soils, removal rates were $>99.99 \%$ at $25 \mathrm{~cm}$. The transport simulation compared (1) optimization, and (2) trial-and-error modeling approaches. Only slight differences between the transport parameters were observed between these approaches. Independent of the fitting procedure, attachment rates computed by the model were higher in sandy and sandy loam soils than clay loam, which was attributed to unsaturated flow conditions at lower water content in the coarser-textured soils. In the second part of this research, bacteria removal efficiencies in a conventional soil-based wastewater treatment system (OWTS) were modeled to elucidate the fate and transport of E. coli under environmental and operational conditions that might be expected under changing
\end{abstract}


climatic conditions. The impact of changing precipitation patterns, initial bacteria concentrations, hydraulic loading rates (HLR), and higher subsurface temperatures at different depths and soil textures on bacteria removal was evaluated. Modeled effects of initial bacteria concentration shows that greater depth of treatment was required in coarser soils than in fine textured ones to remove E. coli. The initial removal percentage was higher when HLR was lower, but it was greater when HLR was higher. When a biomat layer was included in the transport model, the performance of the system improved by up to $12.0 \%$. Lower bacteria removal (up to $5 \%$ ) was observed at all depths under the influence of precipitation rates ranging from $5 \mathrm{~cm}$ to $35 \mathrm{~cm}$, and $35 \mathrm{~cm}$ rainfall combined with a $70 \%$ increase in HLR. C Increased subsurface temperature due to climate change $\left(23^{\circ} \mathrm{C}\right)$ increased bacteria removal relative to a lower temperature range $\left(5{ }^{\circ} \mathrm{C}\right.$ to $\left.20^{\circ} \mathrm{C}\right)$. It appears that the performance of OWTS may be impacted by changing climate. In the third part of this research, we also simulated the fate and transport of $\mathrm{N}$ in three different types of OWTS drainfield, or soil treatment areas (STA) using 2D/3D HYDRUS software to develop a $\mathrm{N}$ transport and fate model. Experimental data from a laboratory mesocosm study, including soil moisture content, and $\mathrm{NH}_{4}$ and $\mathrm{NO}_{3}{ }^{-}$ concentration, was used to calibrate the model and a water content-dependent function was used to compute nitrification and denitrification rates. Three types of drainfields were simulated: (1) pipe-and-stone (P\&S), (2) pressurized shallow narrow drainfield (SND) and (3) Geomat (GEO), a variation of SND. The results showed that the model was calibrated with acceptable goodness-of-fit between the observed and measured (average root mean square errors (RMSE) ranged from 0.18 to 9.65 for $\mathrm{NH}_{4}{ }^{+}$ and $\mathrm{NO}_{3}{ }^{-}$). The model predicted the $\mathrm{N}$ losses from nitrification and denitrification in all 
STAs. The modeled $\mathrm{N}$ losses occurred mostly as $\mathrm{NO}_{3}{ }^{-}$in water Outputs, accounting for more than $82 \%$ of $\mathrm{N}$ inputs in all drainfields. The highest $\mathrm{N}$ losses by denitrification were computed for the P\&S drainfield and accounted for $17.60 \%$ of the influent total N. Our results showed that HYDRUS is a useful tool to predict the fate and transport of nutrients and microbial contaminants and help to provide practitioners with guidelines to estimate pathogens and nutrients removal efficiencies for OWTS under the effect of different operational and environmental factors. In addition, the modeling approach presented in this study, will be useful to predict the extent of contamination and spatial distribution for identifying non-point sources, and establish total minimum daily loads (TMDLs). 


\section{ACKNOWLEDGEMENT}

This research was funded by the Rhode Island Sea Grant and the Rhode Island Experimental Station, and by two Enhancement of Graduate Research Awards from the URI Graduate School.

First, I want to thank God, who has given me the strength and health to achieve this goal; my advisor Dr. Thomas Boving, for his farseeing guidance, endless support and generous help throughout this research. Also, thanks to my faculty committee members: Dr. José Amador and Vinka Oyanadel Craver for their cooperation. Special thanks to Jennifer Cooper for being an excellent and knowledgeable research partner and George Loomis and David Kalen from New England Onsite Wastewater Training Program for their technical support in this project.

I would like to thank all the people that mad my stay easier in Rhode Island: my roommates Varun Kasaraneni and Anna Rose Keefe (for being an amazing roommates in the last two years), as well as Farrah Solomon, Laura Schifman, Hongyin Zhang, Amy Parmenter and Julie Scott. Also, I want to thank Nelson Anaya, for their true friendship and support and for being the person who encouraged me to go for graduate studies again.

I am very grateful to my father Jose Morales, for his financial support. To my beloved mother Mireya Parra, for always taking care of me; I owe her all what I am today. My brothers and sister, Runny, Saul and Rosmery. I want to thank my beloved wife Dinelys and my kids, Lia Marie and Diego, for believing in me and try to make all these days easier. I dedicate this thesis to them. 


\section{PREFACE}

This dissertation is written and organized in manuscript format and in accordance with the University of Rhode Island Graduate School guidelines. The dissertation is divided into five sections, which consist of an introduction, three manuscripts, (published, accepted or in preparation for submission), and conclusions. Chapter 1 is a manuscript entitled "Transport Of Pathogen Surrogates In Soil Treatment Units: Numerical Modeling" with the authors I. Morales, J. Atoyan, J. Amador and T. Boving and has been published to the journal Water. Chapter 2 is a manuscript entitled "Transport of Escherichia coli in a Soil-Based Wastewater Treatment System under Simulated Operational and Climate Change Conditions" with the authors I. Morales, J. Amador and T. Boving and has been accepted for publication in the Journal of Environmental Quality. Chapter 3 is a manuscript entitled "Modeling Nitrogen Losses in a Soil-based Wastewater Treatment System" with the authors I. Morales, J. Cooper, J. Amador and T. Boving and is in preparation to be submitted to the journal PLOS ONE. 


\section{TABLE OF CONTENTS}

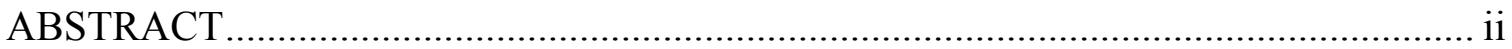

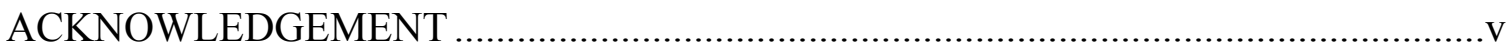

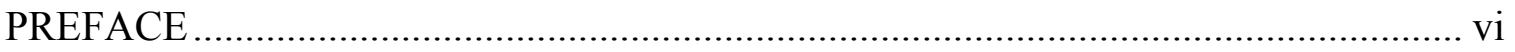

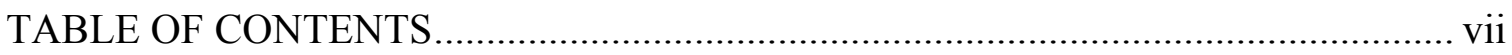

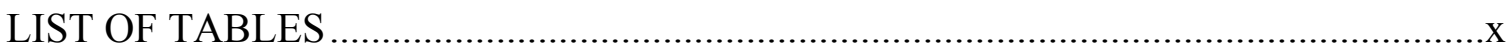

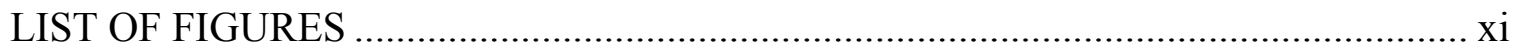

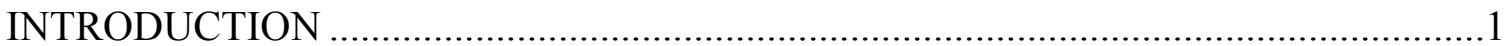

MANUSCRIPT - I: TRANSPORT OF PATHOGEN SURROGATES IN SOIL TREATMENT UNITS: NUMERICAL MODELING …………….................................

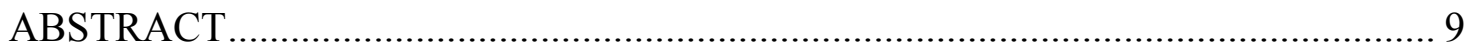

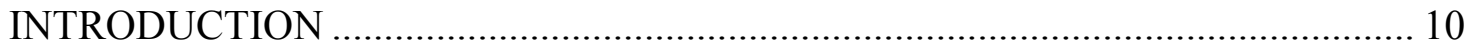

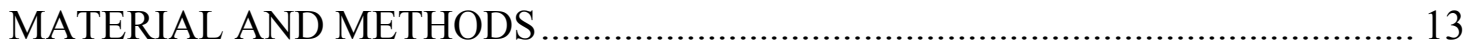

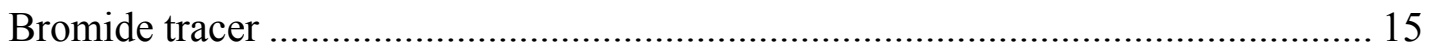

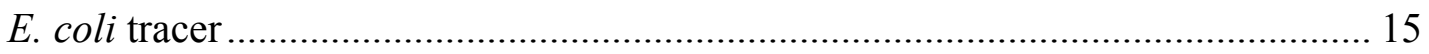

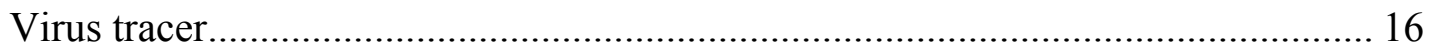

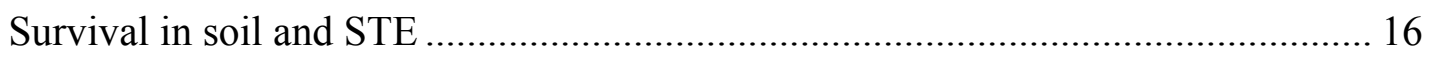

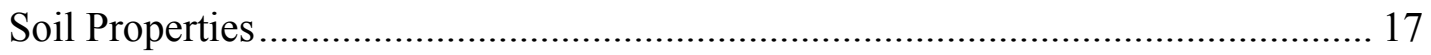

Bacteria and Virus Transport Modeling …………………............................... 18

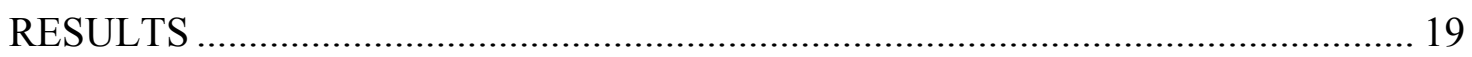

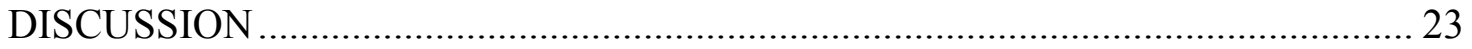

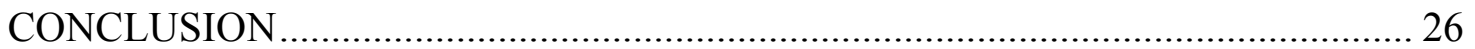

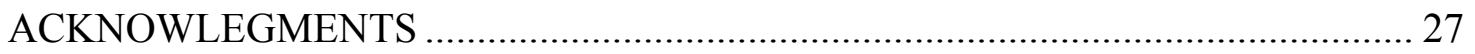

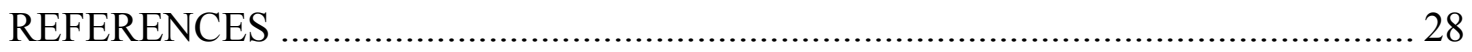

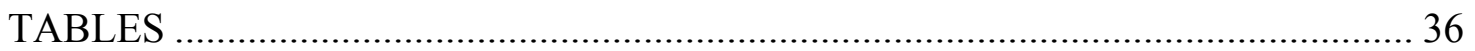

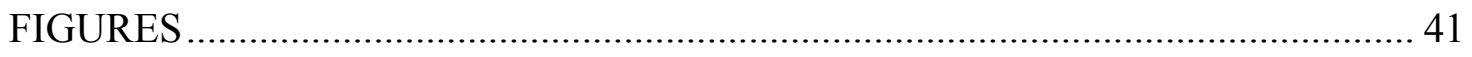

MANUSCRIPT - II: BACTERIA TRANSPORT IN A SOIL-BASED WASTEWATER TREATMENT SYSTEM UNDER SIMULATED OPERATIONAL AND CLIMATE

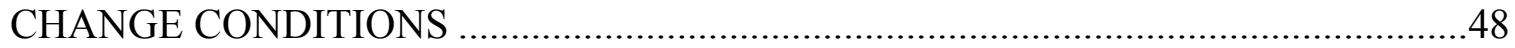

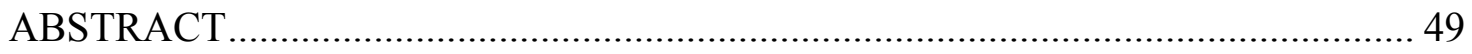

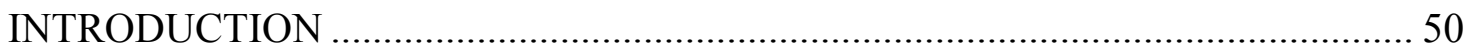




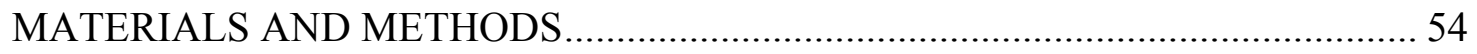

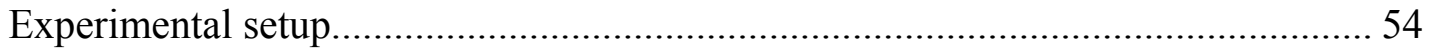

Bacteria transport modeling and parameterization …………………………........ 54

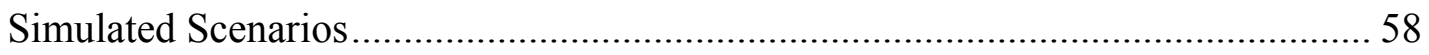

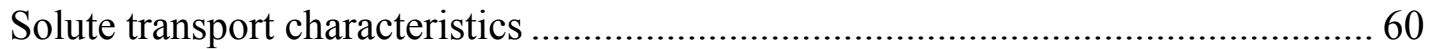

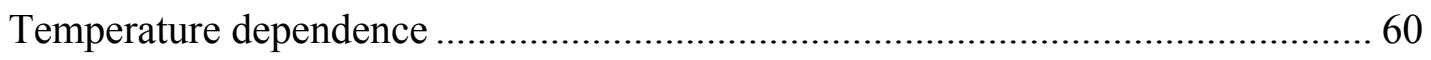

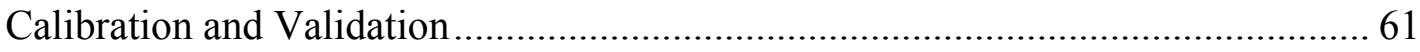

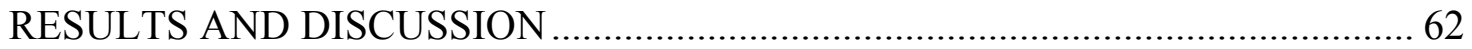

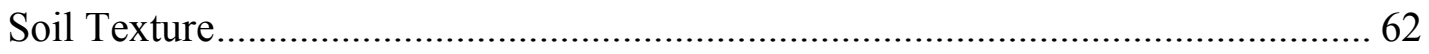

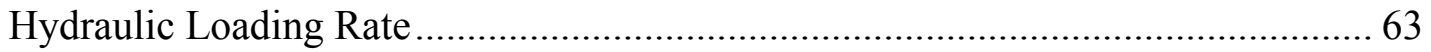

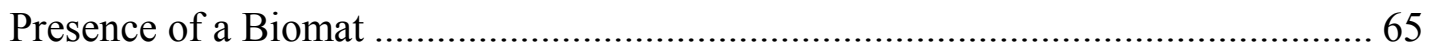

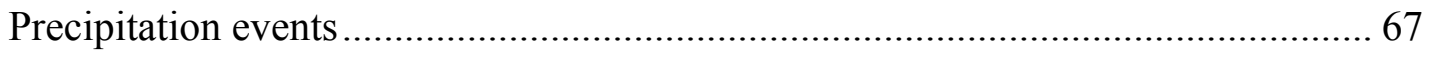

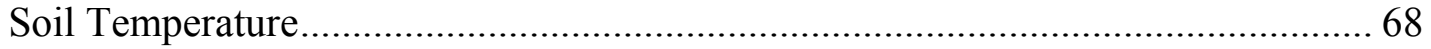

MODEL IMPLICATIONS ON BACTERIA REMOVAL RATES ............................... 71

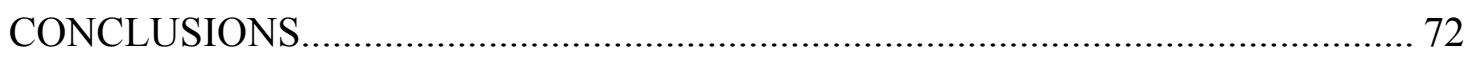

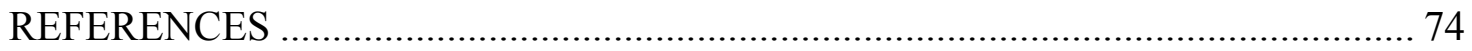

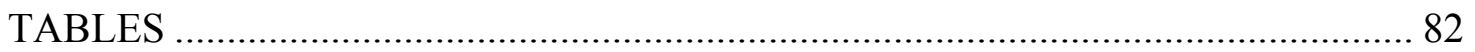

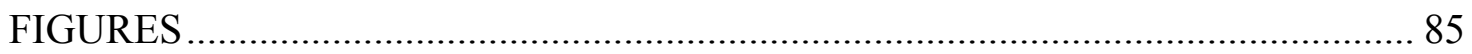

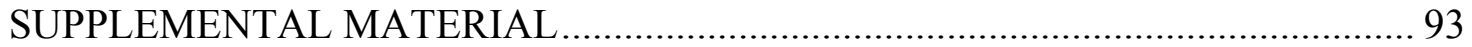

MANUSCRIPT - III: MODELING NITROGEN LOSSES IN CONVENTIONAL AND ADVANCED SOIL-BASED ONSITE WASTEWATER TREATMENT SYSTEMS ....94

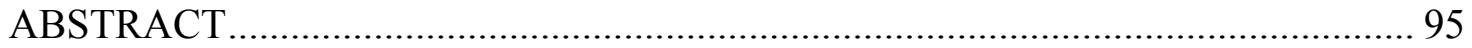

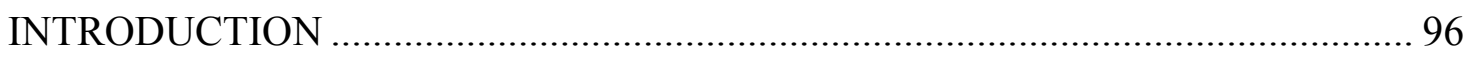

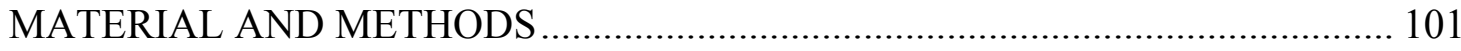

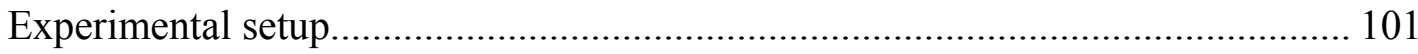

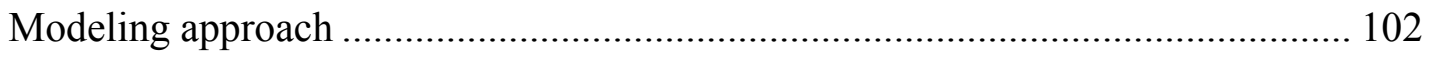

Model domain and boundary conditions............................................................. 104

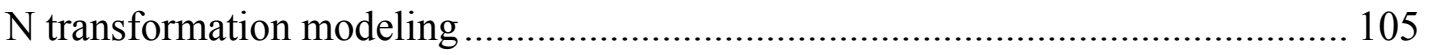

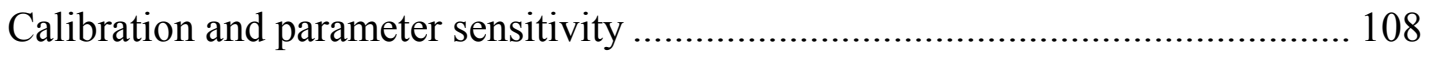

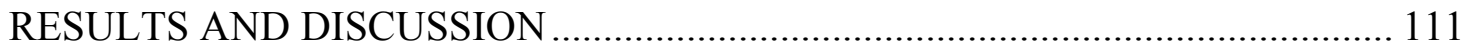

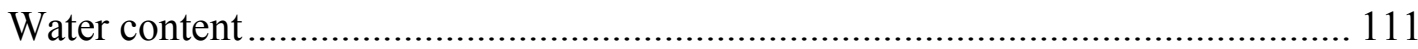




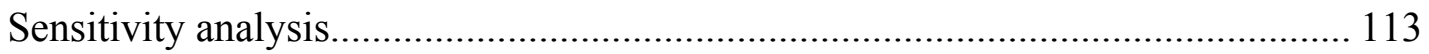

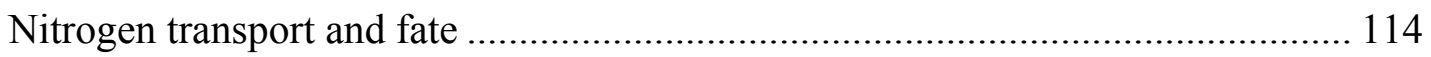

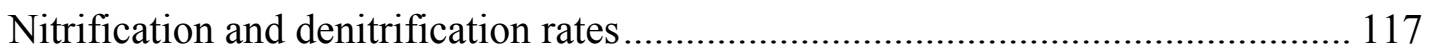

$\mathrm{N}$ losses and comparison between simulated and real systems .............................. 119

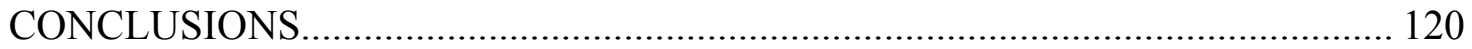

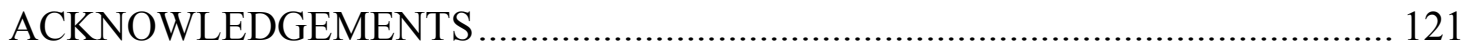

We thank Dr. Mengistu Geza at Colorado School of Mines for his technical support and guidance. This study was funded by USDA Hatch Multi-State Project NE-1045.

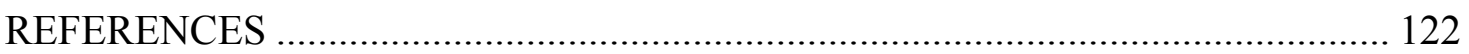

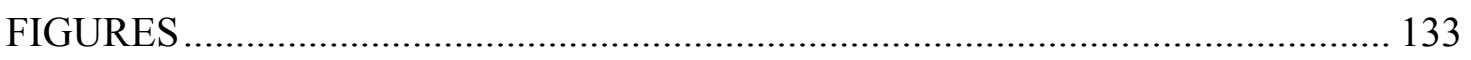

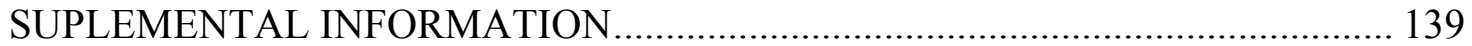

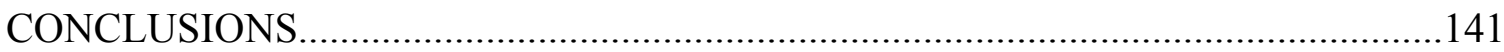

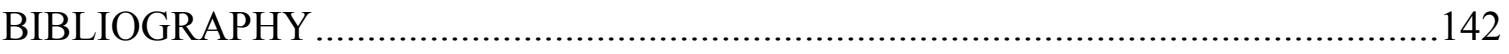




\section{LIST OF TABLES}

Table 1. 1 Soil properties prior (initial, in bold) to septic tank effluent addition, and after

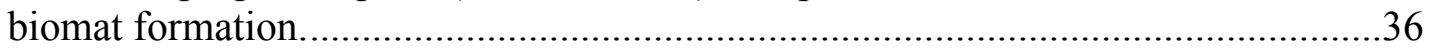

Table 1. 2 Chemical and microbial properties of septic tank effluent (STE) ...................37

Table 1. 3 Measured GFP E. coli die-off rates in soil and septic tank effluent. .38

Table 1. 4 Modeled GFP E. coli and MS-2 phage peak concentrations for sandy, sandy loam, and clay loam soil using optimization or trial-and-error approaches. Values in parentheses are percent removal rates. The microbial tracers $\left(\mathrm{C}_{0}=\right.$ initial concentration) were applied together with STE at a hydraulic loading rate of 2.4 $\mathrm{cm} /$ day every $12 \mathrm{~h}$ over $37 \mathrm{~h}$. BD: below detection limit.

Table 1. 5 E. coli and virus transport parameters derived from HYDRUS 2D/3D [23]. Non-detects of virus tracer in sandy loam and clay soils prevented modeling of these experiments.

Table 2. 1 Soil hydraulic model parameters as generated by Rosetta lite program (Schaap et al., 2001). Those values are based on the U.S. Department of Agriculture (USDA) textural class triangle.

Table 2. 2 Relative and absolute hydraulic conductivity values of the biomat at the trench bottom and sidewalls (Material 3). Also included is the value for the gravel layer (Material 2).

Table 2. 3. Summary of infiltration patterns simulated to stress the trench treatment system.

Table 3. 1 Calibrated soil hydraulic parameters for the simulated advanced and conventional drainfield mesocosms.

Table 3. 2 Composite scale sensitivity ratios to the measured soil moisture data for the silt loam and gravelly-coarse sand soils for PSND, GEO and P\&S.

Table 3. 3 Fitted parameters for nitrification and denitrification water content-dependent function.

Table 3. 4 Modeled water-filled pore space or relative water content for all STA types.131

Table 3. 5 Average zero-order nitrification and denitrification rates for the selected soils and materials in advanced and conventional drainfield mesocosms 


\section{LIST OF FIGURES}

Figure 1. 1 Schematic of experimental setup. Drawing is not to scale.

Figure 1. 2 Hydraulic model domain with (A) observation nodes at $4 \mathrm{~cm}, 14 \mathrm{~cm}$ and 25 cm depths, (B) boundary conditions.

Figure 1. 3 Bromide tracer test results and best fit obtained for the three soil column depth intervals $(0-4 \mathrm{~cm}, 4-14 \mathrm{~cm}$, and $14-25 \mathrm{~cm})$ in sandy soil.

Figure 1. 4 Experimental GFP E. coli data and HYDRUS optimization (left) and trialand-error (right) simulation for the sandy soil at $4 \mathrm{~cm}, 14.5 \mathrm{~cm}$ and $25 \mathrm{~cm}$ depth. The log-normal inserts emphasize the tailing phase.

Figure 1. 5 Experimental GFP E. coli data and HYDRUS optimization (left) and trialand-error (right) simulation for the sandy loam soil at $4 \mathrm{~cm}, 14 \mathrm{~cm}$ and $25 \mathrm{~cm}$ depth. The log-normal inserts emphasize the tailing phase.

Figure 1. 6 Experimental GFP E. coli data and HYDRUS optimization (left) and trialand-error (right) simulation for the clay loam soil at $4 \mathrm{~cm}, 14 \mathrm{~cm}$ and $25 \mathrm{~cm}$ depth. The log-normal inserts emphasize the tailing phase.

Figure 1. 7 Experimental MS-2 phage data and HYDRUS optimization (left) and trialand-error (right) simulation for the sandy soil at $4 \mathrm{~cm}, 14 \mathrm{~cm}$ and $25 \mathrm{~cm}$ depth. The log-normal inserts emphasize the tailing phase.

Figure 2. 1. (A) Conventional onsite wastewater treatment system (OWTS) model domain and porous material distribution, (B) boundary conditions and (C) observation nodes for HYDRUS simulations. All dimensions are in $\mathrm{cm}$.

Figure 2. 2 Effect of soil texture on reduction of $E$. coli concentration at an initial influent E. coli concentration of $10^{5} \mathrm{cfu} \mathrm{mL}^{-1}$. Model concentrations are shown for five observation points located at $10 \mathrm{~cm}, 17 \mathrm{~cm}, 23.3 \mathrm{~cm}, 28 \mathrm{~cm}$ and $42 \mathrm{~cm}$ below the influent pipe (a) and trench sidewall (b).

Figure 2. 3 Reduction of E. coli concentration in sandy, sandy loam, and clay loam soils as a function of variable hydraulic loading rate (HLR; $\mathrm{cm} \mathrm{h}^{-1}$ ) at an influent $E$. coli concentration of $10^{5} \mathrm{cfu} \mathrm{mL}^{-1}$. Model concentrations are shown for five observation points located at $10 \mathrm{~cm}, 17 \mathrm{~cm}, 23.3 \mathrm{~cm}, 28 \mathrm{~cm}$ and $42 \mathrm{~cm}$ below the influent pipe (a) and trench sidewall (b).

Figure 2. 4 Reduction of $E$. coli concentration in sandy, sandy loam and clay loam soils as a function of variable hydraulic conductivity of the biomat layer at an influent $E$. coli concentration of $10^{5} \mathrm{cfu} \mathrm{mL}^{-1}$. The initial hydraulic conductivity of the trench gravel was $83.3 \mathrm{~cm} \mathrm{~h}^{-1}$ and $0.0017 \mathrm{~cm} \mathrm{~h}^{-1}$ for the biomat. Model concentrations are shown for five observation points located at $10 \mathrm{~cm}, 17 \mathrm{~cm}, 23.3 \mathrm{~cm}, 28 \mathrm{~cm}, 42 \mathrm{~cm}$ 
and $70 \mathrm{~cm}$ below the influent pipe (a) and trench sidewall (b). Numbers in the legend are initial hydraulic conductivity multipliers.

Figure 2. 5 Flow direction indicated by velocity vectors in the trench after 96 hours operation for the sandy soil with sidewall and bottom biomat hydraulic conductivity equal to: (A) $0.01 \mathrm{Ks}$, (B) $0.1 \mathrm{Ks}$, (C) Ks, and (D) $5.0 \mathrm{Ks}$. In all scenarios, the STE enters the trench through the horizontal drain pipe, flows out of the trench, and infiltrates into the bottom and sidewall. When the biomat is simulated under low conductivity values, no flow is observed through the trench bottom; instead, STE flows over the sidewall biomat on the right and $E$. coli concentration increases. Similar results were observed for sandy loam and clay loam soils (not shown)......89

Figure 2. 6 Reduction of $E$. coli concentration in sandy, sandy loam, and clay loam soils as a function of variable surface infiltration events at an influent $E$. coli concentration of $10^{5} \mathrm{cfu} \mathrm{mL}^{-1}$. Model concentrations are shown for five observation points located at $10 \mathrm{~cm}, 17 \mathrm{~cm}, 23.3 \mathrm{~cm}, 28 \mathrm{~cm}, 42 \mathrm{~cm}$ and $70 \mathrm{~cm}$ below the influent pipe (a) and trench sidewall (b). No results are shown for clay soil (see text for details).

Figure 2. 7 Reduction of $E$. coli concentration in sandy, sandy loam, and clay loam soils as a function of variable soil temperature, under moderate to warmer $\left(5^{\circ} \mathrm{C}\right.$ to $\left.20{ }^{\circ} \mathrm{C}\right)$ and under climate changing conditions $\left(23^{\circ} \mathrm{C}\right)$, at an influent $E$. coli concentration of $10^{5} \mathrm{cfu} \mathrm{mL}^{-1}$. Model concentrations are shown for five observation points located at $10 \mathrm{~cm}, 17 \mathrm{~cm}, 23.3 \mathrm{~cm}, 28 \mathrm{~cm}$ and $42 \mathrm{~cm}$ below the influent pipe (a) and trench sidewall (b).

Figure 2. 8 Effect of temperature on E. coli removal for sandy, sandy loam, and clay loam soils at $10 \mathrm{~cm}, 17 \mathrm{~cm}, 23.3 \mathrm{~cm}, 28 \mathrm{~cm}, 42 \mathrm{~cm}, 70 \mathrm{~cm}$ and $105 \mathrm{~cm}$.

Figure 3. 1 Model domain and porous material distribution for PSND, GEOMAT and pipe and stone. All dimensions are in $\mathrm{cm}$.

Figure 3. 2 Boundary conditions for (a) PSND, (b) GEOMAT and (c) Pipe and stone soil drainfield mesocosms.

Figure 3. 3 Observed and simulated water content for (a) PSND, (b) GEOMAT and (c) Pipe and stone drainfield mesocosms. Root mean square error is included as a measure of the goodness-of-fit between predicted and observed data.

Figure 3. 4 Pressure head distribution as a result of the seepage boundary condition to simulate a hanging water table at the bottom of the mesocosms. At steady state, pressure head values are close to zero, which indicates that area is near or under saturation conditions.

Figure 3. 5 Predicted and measured $\mathrm{NH}_{4}{ }^{+}$concentrations for (a) PSND, (b), GEO and (c) P\&S. 
Figure 3. 6 Predicted and measured $\mathrm{NO}_{3}{ }^{-}$concentrations for (a) PSND, (b), GEO and (c)

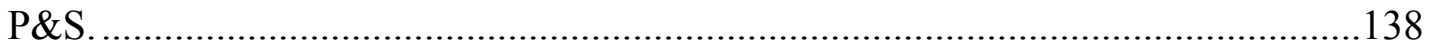




\section{INTRODUCTION}

The use of onsite wastewater treatment systems (OWTS) for wastewater renovation is a common practice in the U.S., especially in rural areas where the access to centralized wastewater treatment systems is limited. These systems treat billions of gallons of wastewater per day (US EPA, 2002). Due to the increasing density of OWTS in rural and suburban areas, it is important to apply quantitative tools to evaluate OWTS performance and predict potential cumulative effects of OWTS on public health and environmental quality.

Onsite wastewater treatment systems treat residential wastewater - consisting of both black water (urine and fecal matter) and grey water (shower, laundry, kitchen) (EPA, 2002) - in a series of steps that begin with primary treatment, or initial settling of bulk solids, in the septic tank. In a conventional pipe and stone (P\&S) system, septic tank effluent (STE) is dispersed directly to a soil treatment area (STA), or drainfield, without further treatment. In advanced technologies, prior to dispersal onto the STA, STE is treated further to achieve substantial removal of contaminants, reducing the contaminant load to the STA and lessening reliance on the soil for wastewater renovation.

Ineffective OWTS are a source of microbial pathogens (bacteria and viruses), which are one of the major cause of contamination and water quality impairments in surface water in U.S. (US EPA, 2010). Many pathogenic microorganisms require relatively small numbers to cause infection and induce illness in humans. In order to avoid microbial contamination, US EPA recommends a separation distance of $45 \mathrm{~cm}$ 
between the infiltrative of surface of the STA and the water table, regardless of soil chemical and physical properties (US EPA, 2002).

Another wastewater-derived contaminant that can produce water impairments is nitrogen $(\mathrm{N})$, particularly nitrate $\left(\mathrm{NO}_{3}{ }^{-}\right)$. The presence of nitrate in drinking water is the principal cause of methemoglobinemia, which affects the ability of red blood cells to bind oxygen (Shuval \& Gruener, 2013). Non-Hodgkin's lymphoma is assumed to be caused by $\mathrm{NO}_{3}{ }^{-}$when present in concentrations above $4 \mathrm{mg} \mathrm{N} / \mathrm{L}$ in drinking water (Ward et al., 1996). In addition, high nitrate loads discharged into surface water or marine environments can affect water quality by stimulating eutrophication (Brandes et al., 1974; Weiskel and Howes, 1992).

Nitrogen is present in septic tank effluent as ammonium $\left(\mathrm{NH}_{4}{ }^{+}\right)$. When ammonium is added to the STA, it is absorbed to the soil particles or used as an electron donor by nitrifying bacteria under aerobic conditions via nitrification. Unlike ammonium, $\mathrm{NO}_{3}{ }^{-}$is a conservative anion that can travel through the soil profile until it reaches groundwater. Under anaerobic conditions, nitrate in the soil pore water is used as an electron acceptor by denitrifying bacteria, and is converted into nitrogen gas $\left(\mathrm{N}_{2}\right)$ or nitrous oxide gas $\left(\mathrm{N}_{2} \mathrm{O}\right)$, which accounts as possible losses of $\mathrm{N}$ in the STA.

To describe contaminant transport in STAs, deterministic and mechanistic models have been used. Computerized mechanistic models have been applied to assess the transport of pathogenic microorganisms (Shelton et al., 2003; McGechan and Vinten, 2003; Pang et al., 2008), nutrients such as N (Beggs et al., 2004; Heatwole and McCray, 2007; Hassan et al., 2008) and an increasing number of other types of contaminants 
(Cooper et al., 2015). These models consider that the movement of solute through the soil is the result of the physical process of convection, or mass flow, of water and the chemical process of diffusion in response to a concentration gradient (Addiscott and Wagenet, 1985). The solute transport is characterized in a porous media by an ensemble of pore velocities that exist due to microscopic and macroscopic variations in pore size, tortuosity of flow path and the distribution of both water and solutes within partially water-filled pores. A solute introduced into such a flow system will thereby spread, or disperse, as it is convectively and diffusively transported through the soil.

Mathematical models can be useful tools to describe the transport and fate of microorganisms in the subsurface and understand the influence of individual transport parameters on controlling microbial concentrations in soil media. Some models evaluate bacteria transport based on biomass development on the subsurface (Baveye and Valocchi, 1989). In this approach, biomass is assumed to be developed over the soil particles (biofilm), where scattered colonies in oligotrophic environments exist. Microbial matter modeling has mostly focused on transport of viruses. Azadpour-Keeley et al. (2003) performed a review of existing mathematical models for virus transport simulation. The list included:

- VIRALT, is a modular semi-analytical and numerical code that simulates the single-source transport and fate of viruses in the saturated and unsaturated zones (Park et al., 1992). The code considered that viruses are transported by advection, dispersion and sorption. Also includes virus inactivation. 
- CANVAS, is a model derived from VIRALT and in addition, the code models transport by colloidal matter and the simulation of multiple contaminants sources (Park et al., 1993).

- VIRTUS, which stands for "virus transport in unsaturated soils", the model predicts the virus fate and transport in unsaturated soils and allows the virus inactivation as a function of changes in soil temperature (Yates and Ouyang, 1992).

- VIRULO is a probabilistic model to model leaching of viruses in the unsaturated zone. VIRULO uses a Monte Carlo simulation method to produce an array of scenarios of virus attenuation due to physical, biological and chemical factors (Faulkner et al., 2003).

- 3DFATMIC, is a three-dimensional subsurface transport and fate model developed to simulate transient and/or steady-state density-dependent flow field and transient and/or steady-state distribution of a substrate, a nutrient, and an aerobic or anaerobic electron acceptor in a three-dimensional domain of subsurface media. The code is based on the generalized Richards equation and Darcy's law which are simulated with the Galerkin FEM (Yeh et al., 1997).

HYDRUS is a two- and three-dimensional, finite-element transport model to simulate water and temperature-dependent solute movement in variably-saturated porous media (Simunek et al, 2012). The model solves the Richards equation for saturatedunsaturated water flow and the convection-dispersion equation for heat and solute transport. Also, HYDRUS includes the attachment-detachment and filtration theories to simulate the transport of viruses and bacteria in the subsurface. For our study, HYDRUS 
2D/3D version 2.0 was used to model chemical and biological contaminants under variable environmental conditions because of its versatility and user-friendly interface.

In Manuscript I, we examined the extent to which removal of two types of microbial pathogens (viruses and bacteria) is affected by soil texture and depth. In this experiment, the survival of the coliphage virus and tracer bacterium was measured in sterile and non-sterile unsaturated soil and septic tank effluent. Segmented mesocosms (n =3) were packed with sand, sandy loam and clay loam soil, and connected to each other with plastic tubing. Sampling ports were located between mesocosms to allow for collection of drainage water directly below the infiltrative surface $(4 \mathrm{~cm})$ and at succeeding $10.5 \mathrm{~cm}$ depths intervals $(14.5 \mathrm{~cm}, 25 \mathrm{~cm}$ and $35.5 \mathrm{~cm})$. The collected data were used to model microbial transport, estimate transport parameters model and validation using HYDRUS 2D/3D. The model predicted the transport and attenuation of bacteria and virus in soils with different texture and structure. The bacteria and viruses were removed completely by mechanical filtration (Sobsey \& Shields, 1987) and adsorption to soil particles (Goyal \& Gerba, 1979; Dowd et al., 1998), respectively. The model determined water-content dependent attachment-detachment rates for microbial pathogens in order to calculate reduction values, which was higher in fine-texture soils than in granular soils at a given water content.

Projections of climate conditions in parts of US, including the Northeast, indicate that sea level, rainfall rates and temperatures have been on the rise and will continue to do so during the next 100 years (Kirtman et al., 2013). The effect of climate of change and sea level rise may affect the performance of the OWTS in coastal areas or in areas with shallow water tables. Changes of ambient temperature will influence the availability 
and consumption of oxygen by soil microorganisms, which have an effect on microbial processes. Sea level rise, as well as increased precipitation and infiltration may reduce the vertical separation between the infiltrative surface and the groundwater. As a result, less unsaturated soil will be available and the ability of soil to remove contaminants (BOD, N, $\mathrm{P}$ and pathogens) through chemical and biological processes may be diminished.

In Manuscript II, the fate and transport of E. coli bacteria was modeled under operational and climate change conditions using HYDRUS 2D/3D software. The performance of the OWTS was affected by the formation of a biomat, variation in hydraulic loading rates, hydraulic conductivity, temperature and precipitation events. The model was able to simulate bacteria removal under the effects of extreme precipitation events and elevated temperature at different depths and soil textures. Increased subsurface temperature due to climate change $\left(23^{\circ} \mathrm{C}\right)$ increased bacterial removal relative to a lower relative range $\left(5-20{ }^{\circ} \mathrm{C}\right)$. At 10 -cm depth, the removal rate was increased from $20 \%$ at $5{ }^{\circ} \mathrm{C}$ to $71.9 \%$ at $20{ }^{\circ} \mathrm{C}$. Our results indicate that the performance of OWTS may be impacted by changing climate.

Few models have been developed for fate and transport of N in the STA. Most are simple models designed to predict the $\mathrm{NO}_{3}{ }^{-}$concentration in groundwater beneath subdivisions or geographically-divided sites located in different areas across the country (the models were applied in California and Massachusetts) using OWTS due to dilution effects (Frimpter et al., 1990; Weintraub et al., 2004). In Manuscript III we developed a model to simulate and predict nitrogen losses in shallow narrow drainfield, GeoMat and conventional pipe and stone STAs. Losses of $\mathrm{N}$ from $\mathrm{P} \& \mathrm{~S}$ were predicted to occur predominantly as $\mathrm{N}_{2}$ gas (and $\mathrm{N}_{2} \mathrm{O}$ to a lesser extent) from denitrification due to more 
anaerobic conditions in the drainfield, lower input dissolved $\mathrm{O}_{2}$ and higher organic $\mathrm{C}$ available as BOD for use as an electron donor. $\mathrm{SND}$ and GEO produced little $\mathrm{N}_{2}$ production due to limited organic $\mathrm{C}$ levels and higher $\mathrm{O}_{2}$ availability, making it unlikely that sufficiently anaerobic conditions would develop. The model predicted the removal of nitrogen and water content-dependent, zero-order decay and transformation rates for nitrification and denitrification. The modeled $\mathrm{N}$ losses occurred mostly as $\mathrm{NO}_{3}{ }^{-}$in water outputs, accounting for more than $82 \%$ of $\mathrm{N}$ inputs in all drainfields. The highest $\mathrm{N}$ losses as $\mathrm{N}_{2}$ were computed for the P\&S drainfield and accounted for $17.60 \%$ of the influent total N. However, only $10.44 \%$ and $9.65 \%$ was converted to $\mathrm{N}_{2}$ in SND and Geo drainfields, respectively. 


\title{
MANUSCRIPT - I: TRANSPORT OF PATHOGEN SURROGATES IN SOIL TREATMENT UNITS: NUMERICAL MODELING
}

published in Water, April 2014

\author{
Ivan Morales ${ }^{1}$, Janet A. Atoyan ${ }^{2}$, José A. Amador ${ }^{2}$ and Thomas Boving ${ }^{1,3, *}$ \\ 1 Department of Civil and Environmental Engineering, University of Rhode Island, Kingston, RI 02881 \\ 2 Laboratory of Soil Ecology and Microbiology, University of Rhode Island, Kingston, RI 02881 \\ 3 Department of Geosciences, University of Rhode Island, Kingston, RI 02881
}

* Corresponding author: Thomas Boving

Department of Geosciences

Woodward Hall, Rm. 314

University of Rhode Island

Kingston, RI 02881

E-Mail: boving@uri.edu 


\section{ABSTRACT}

Segmented mesocosms $(n=3)$ packed with sand, sandy loam or clay loam soil were used to determine the effect of soil texture and depth on transport of two septic tank effluent (STE)-borne microbial pathogen surrogates - green fluorescent protein-labeled E. coli (GFPE) and MS-2 coliphage - in soil treatment units. HYDRUS 2D/3D software was used to model the transport of these microbes from the infiltrative surface. Mesocosms were spiked with GFPE and MS-2 coliphage at $10^{5} \mathrm{cfu} / \mathrm{ml} \mathrm{STE}$ and $10^{5}-10^{6} \mathrm{pfu} / \mathrm{ml} \mathrm{STE}$ respectively. In all soils, removal rates were $>99.99 \%$ at $25 \mathrm{~cm}$. The transport simulation compared (1) optimization, and (2) trial-and-error modeling approaches. Only slight differences between the transport parameters were observed between these approaches. Treating both the die-off rates and attachment/detachment rates as variables resulted in an overall better model fit, particularly for the tailing phase of the experiments. Independent of the fitting procedure, attachment rates computed by the model were higher in sandy and sandy loam soils than clay, which was attributed to unsaturated flow conditions at lower water content in the coarser-textured soils. Early breakthrough of the bacteria and virus indicated the presence of preferential flow in the system in the structured clay soil (clay soil, GA), resulting in faster movement of water and microbes throughout the soil relative to a conservative tracer (bromide). 


\section{INTRODUCTION}

Septic tank effluent (STE) contains pathogenic microorganisms, such as enteric viruses and bacteria, which can cause waterborne diseases and pose a public health risk if not properly treated. Onsite wastewater treatment systems (OWTS) are commonly used in suburban and rural areas in the United States and elsewhere. A conventional OWTS consists of a septic tank and associated soil treatment area (STA), or drainfield, where attenuation and/or removal of microbial contaminants can take place through interactions with the soil, preventing their migration to groundwater. Nevertheless, contamination of groundwater below the STU is a concern, especially in areas with shallow groundwater tables.

In order to protect drinking water, the separation distance between the infiltrative surface of the STA and fluctuating water table has to be determined on site-by-site basis, and seasonal variations in separation distance have to be considered to avoid microbial contamination. The US EPA [1] recommends a minimum separation distance of $45 \mathrm{~cm}$, regardless of soil chemical and physical characteristics. However, separation distance requirements in the US vary widely by state, region and sensitivity of receiving waters to contaminant load. Furthermore, differences in soil properties (e.g. texture, structure, $\mathrm{pH}$ ) are known affect STU performance, which may lead to differences in removal of viruses and bacteria [1-3].

A number of studies have investigated the removal efficiency of bacteria in STAs and the processes involved. Crites [4] suggested that bacterial removal or inactivation in STAs is associated with predation by bactrivorous organisms and exposure to sunlight. Mechanical filtration and adsorption, and flow rate also have a significant effect on 
removal of pathogenic bacteria $[2,5,6]$. All of these processes are influenced by soil texture and structure. Fine textured and poorly structured soils are expected to remove bacteria mainly through mechanical filtration because of the smaller pore sizes and lower hydraulic conductivity of those soils. Together with a greater surface area, this results in higher rates of bacteria adsorption [2]. In contrast, coarse and well-structured soils have larger pores and lower porosity values, which allows for better aeration that promotes microbial predation and attenuation [7].

Viruses are thought to be removed in STAs through adsorption to soil particles rather than by mechanical filtration[8,9]. Viruses have a smaller diameter compared to soil pores, which prevents them from being trapped in the pore space. Adsorption of viruses is a function of the physical and chemical properties of the soil, particularly $\mathrm{pH}$, organic matter content and water content [10-13].

Mature OWTS systems develop a biological growth layer of low permeability at the infiltrative surface of the STA, known as a biomat. Typically, the biomat extends up to 2 $\mathrm{cm}$ below the water-soil interface $[14,15]$. It may enhance the inactivation of microbes through mechanical filtration because partial clogging of smaller soil pores results in reduced infiltration rates and the development of unsaturated flow conditions in the underlying soil profile [14-15]. Unsaturated flow conditions result in longer contact times between microbes and soil particles, which improves the pathogen removal efficiency of the soil treatment zone [15-16].

The retention of microorganisms in soil can be affected by preferential flow, which may be associated with pathways created by plant roots and earthworms, the presence of 
interaggregate spaces $[17,18]$, and differences in hydraulic conductivity within the soil strata [19]. Preferential flow increases the travel velocity of the aqueous phase, allowing for faster and deeper movement of microbes into the soil profile [20-22].

The complex nature of pathogen removal and inactivation in the STA presents a difficult problem with respect to predicting OWTS effectiveness. Contaminant transport models can be used to predict the microbial transport in soils and to help elucidate the factors that control microbial fate as STE moves through the soil profile.

Several models have been developed to simulate virus and bacteria transport in soil. The commercially-available HYDRUS software package is widely used to simulate microbial transport and fate processes, including the transport of viruses, bacteria, and colloids based on either attachment/detachment theory or filtration theory in variably saturated porous media[22-26]. The model supports an interactive graphics-based user interface, and the computational program numerically solves the Richards equation for variably saturated water flow, and the advection-dispersion equations for both heat and solute transport. There are HYDRUS versions available with one-, two- and three-dimensional transport modeling capabilities.

The use and calibration of sophisticated transport models, like HYDRUS 2D/3D, permits investigation of the role of microbial inactivation, removal, and transport processes in homogeneous/heterogeneous soil media by quantifying parameters, such as die-off rates in water and soil or attachment/detachment rates [23]. The calibrated transport parameters can be used to calculate microbial removal as a function of distance between the infiltrative surface and the water table, thus permitting comparison among different soils. 
HYDRUS is a valuable and accepted tool for drinking water protection and water resources management purposes. Because of its many capabilities and multi-dimensional functionality, HYDRUS 2D/3D was chosen for modeling our test data.

The objectives of our research project were to: (1) determine the extent to which removal of two microbial pathogen surrogates - a coliphage virus and a tracer bacterium - is affected by soil texture and depth, (2) measure the survival of the coliphage virus and tracer bacterium in sterile and non-sterile unsaturated soil and in STE, and (3) model microbial transport and estimate transport parameters. The results were intended to define and evaluate the potential risk of microbial contamination of groundwater resulting from soil-based treatment of STE. In this paper, we focus on the modeling of microbial transport and how different approaches to modeling - numerical optimization versus visual assessment - best describe experimental data. .

\section{MATERIAL AND METHODS}

Replicate $(n=3)$ segmented mesocosms were constructed to investigate the removal of microbial pathogen surrogates. The mesocosms consisted of straight-sided polypropylene Nalgene jars (10.5 cm height, $6.5 \mathrm{~cm}$ dia.) connected to each other with plastic tubing

(Figure 1. 1). Sample ports between jars allowed for collecting drainage water directly below the infiltrative surface $(4 \mathrm{~cm})$, and at succeeding 10.5 -cm depths intervals $(14.5$ $\mathrm{cm}, 25 \mathrm{~cm}, 35.5 \mathrm{~cm}$ ), hereafter referred to as $4 \mathrm{~cm}, 14 \mathrm{~cm}, 25 \mathrm{~cm}$, and $35.5 \mathrm{~cm}$. The mesocosms were packed with (1) a sandy, B and C horizon soil from Kingston, Rhode Island, U.S.A., (2) a sandy loam soil from Golden, Colorado, U.S.A., or (3) a structured clay loam soil from Griffin, Georgia, USA. These soils are typical of STAs in their respective areas. Select physical and chemical properties for these soils are shown in 
Table 1. 1. The remaining space in the top, $4 \mathrm{~cm}$ mesocosm was packed with gravel to simulate a layer of rock that is typically placed at the bottom of conventional OWTS leachfield trench. After initial packing, the mesocosms were saturated by pumping three pore volumes of clean water upward from the bottom of the mesocosms. Afterwards, the water was allowed to drain freely. The mesocosms were maintained in the dark at room temperature $\left(19-21^{\circ} \mathrm{C}\right)$.

Septic tank effluent was obtained every 7-10 days from an OWTS serving a group home managed by the Rhode Island Department of Mental Health, Rehabilitation and Hospitals in southern Rhode Island, and stored in the dark at room temperature. Select chemical and microbiological properties of the STE are provided in Table 1.2. STE was applied to the infiltrative surface of the mesocosms every $12 \mathrm{~h}$ at a rate of $2.4 \mathrm{~cm} /$ day $(0.6 \mathrm{~g} / \mathrm{sq}$. ft./day) using a programmable peristaltic pump (IsmaTec, IDEX Health and Science GmBH, Wertheim, Germany). To mimic the soil atmosphere of a full-scale operating STU trench at the infiltrative surface, the headspace of the top mesocosm $(4 \mathrm{~cm})$ was vented to a $30-\mathrm{cm}$ column of soil. Vacuum pressure of $-7 \mathrm{kPa}$ was used to approximate the capillary suction from underlying unsaturated soil. Water samples were collected either $3 \mathrm{~h}$ to $5 \mathrm{~h}$ after dosing (sandy and sandy loam soils) or during dosing (clay loam soil). The samples were withdrawn from the sample ports below the mesocosms using UV-sterilized glass vials and a mild vacuum, with 1-3 $\mathrm{ml}$ of water collected from each mesocosm per sampling event.

STE was analyzed for dissolved oxygen immediately after collection using the azide modification of the Winkler titration method [27]. The $\mathrm{pH}$ was determined using a combination $\mathrm{pH}$ electrode and a Model UB-10 pH meter (Denver Instruments, Denver, 
CO). STE was analyzed for fecal coliform bacteria using the membrane filtration method [27], and, for bacteriophage capable of growing on E. coli (K12), using the plaqueforming assay of Adams [28][1]. Five-day biochemical oxygen demand $\left(\mathrm{BOD}_{5}\right)$ was determined following standard procedures [27]. Total $\mathrm{P}$ and total $\mathrm{N}$ were measured in STE using the persulfate digestion method [27], followed by colorimetric analysis[2930].

\section{Bromide tracer}

Bromide (Br-) is a conservative tracer that permits measuring the breakthrough time of the aqueous solution and relates it to the (retarded) transport of either the bacterial or viral tracers. Tracer tests were conducted by spiking the STE influent with $\mathrm{KBr}(\sim 20 \mathrm{mg}$ $\left.\mathrm{Br}^{-} / 1\right)$. Bromide concentrations were measured using the method of Lepore and Barak [2]. The bromide tracer test data were analyzed with the public domain model CXTFIT to determine the dispersivity $(\lambda)$ value of each test material [32]. The data were then used for calibration of the transport model.

\section{E. coli tracer}

A novel strain of E. coli (BTF 132) (Biomérieux, Hazelwood, MO) was used as a bacterial tracer. The strain has a gene for the production of green fluorescent protein (GFP) inserted into the chromosome. Because the gene is chromosomal and not easily lost, this GFP-labeled E. coli strain is ideal for use as a bacterial tracer [33][3]. Bacterial colonies formed on agar plates glow green under UV light; therefore, it is possible to differentiate between the bacteria that were added to the mesocosms and native fecal coliform bacteria, which do not fluoresce. For each bacterial addition experiment, GFP 
E. coli were grown overnight at $37^{\circ} \mathrm{C}$ in lysogeny broth (LB) and then diluted in phosphate-buffered saline (PBS) solution to $\sim 5 \times 10^{6} \mathrm{cfu} / \mathrm{ml}$. Approximately $10 \mathrm{ml}$ of the diluted GFP E. coli culture was added to each mesocosm over a 37-h period, coincident with the STE dosings (a total of four, 2.5-ml doses). GFP E. coli were enumerated using a membrane filtration method with visualization under UV light [27].

\section{Virus tracer}

The bacteriophage MS-2 was used as a tracer. MS-2 is a single-stranded RNA coliphage with a 25-nm diameter and an isoelectric point of 3.9 [13]. E. coli strain K12 was used as the host for the bacteriophage. MS-2 bacteriophages were obtained from the Colorado School of Mines (Golden, CO). For each virus addition experiment, MS-2 was diluted in PBS to $\sim 5 \times 10^{6} \mathrm{pfu} / \mathrm{ml}$ and added as described above for the $E$. coli tracer experiment. The bacteriophage in the collected samples were enumerated using the plaque-forming assay of Adams [28] on LB agar plates, which were incubated for $\sim 4$ h at $37^{\circ} \mathrm{C}$, followed by incubation at room temperature overnight before counting plaques in the host lawn.

\section{Survival in soil and STE}

Experiments were conducted to determine the survival of the microbial pathogen surrogates in soil and STE. For soil, 2 g (air-dry weight) of soil from each of the three soil types were placed in plastic scintillation vials, in triplicate. Prior to use, the soil was either air-dried or sterilized $\left(121^{\circ} \mathrm{C}\right.$ for $60 \mathrm{~min}$ on 5 consecutive days). GFP E. coli or MS-2 bacteriophage suspension was added to the soil to final concentration of $\sim 2.4 \times 10^{5}$ cfu $(\mathrm{pfu}) / \mathrm{g}$ soil. Three replicate vials were sacrificed periodically to enumerate the pathogen surrogates. Microorganisms were extracted with $20 \mathrm{ml}$ of either sterile PBS (for 
E. coli) [34][4] or sterile $1.5 \%$ beef extract, $\mathrm{pH} 8.7$ (for MS-2) [13] added to each vial, after which the vials were placed on a reciprocal shaker for $10 \mathrm{~min}$. GFP E. coli and MS2 bacteriophage were then enumerated as described above.

To determine survival in STE, four 250-ml polypropylene bottles containing $100 \mathrm{ml}$ of effluent were amended with (1) $\sim 4.8 \times 10^{2}$ cfu GFP E. coli $/ \mathrm{ml},(2) \sim 5.2 \times 10^{6} \mathrm{cfu}$ GFP $E$. coli $/ \mathrm{ml}$, (3) $\sim 2.3 \times 10^{2}$ pfu MS-2 coliphage $/ \mathrm{ml}$, or (4) $\sim 4.4 \times 10^{6} \mathrm{pfu}$ MS-2 coliphage $/ \mathrm{ml}$. The bottles containing the amended STE were then incubated at room temperature, in the dark. Samples were analyzed for E. coli and MS-2 as described above. Initial concentrations were determined by identical dilutions using PBS in place of STE followed by immediate enumeration. This experiment was repeated three times.

\section{Soil Properties}

The three soils (sand, sandy loam, and clay loam soil, respectively) were analyzed prior to the start of the experiment and after STE dosing for 27, 31 and 44, weeks. After 27 weeks, all mesocosms had developed a biomat layer that extended over the entire thickness of the gravel layer $(4 \mathrm{~cm})$ at the infiltration surface. The total carbon and nitrogen content of the soil was determined using a Carlo Erba EA1108 CHN analyzer (Lakewood, NJ). The soil $\mathrm{pH}$ was determined using a $1: 5$ soil/water ratio with a combination $\mathrm{pH}$ electrode and a Model UB-10 pH meter (Denver Instruments). Particle size analysis was conducted using the pipette method [35]. The water content was determined gravimetrically. 


\section{Bacteria and Virus Transport Modeling}

HYDRUS 2D/3D was used to simulate the transport of microbes in the segmented mesocosms at different depths. The model simulates virus and bacteria transport and fate processes based on a modified form of the convection-dispersion equation [23] (Eq.1):

$$
\frac{\partial \theta \mathrm{C}}{\partial \mathrm{t}}+\rho \frac{\partial \mathrm{S}_{\mathrm{e}}}{\delta \mathrm{t}}+\rho \frac{\partial \mathrm{S}_{1}}{\delta \mathrm{t}}=-\frac{\delta \mathrm{q}_{\mathrm{i}} \mathrm{C}}{\delta \mathrm{x}_{\mathrm{i}}}+\frac{\delta}{\delta \mathrm{t}}\left(\theta \mathrm{D}_{\mathrm{ij}}^{\mathrm{w}} \frac{\delta \mathrm{C}}{\delta \mathrm{x}_{\mathrm{j}}}\right)-\mu_{\mathrm{w}} \theta \mathrm{C}-\mu_{\mathrm{s}} \rho\left(\mathrm{S}_{\mathrm{e}}+\mathrm{S}_{1}\right)
$$

where $C$ and $S$ are the (virus, bacteria) solution concentration $\left[N c \mathrm{~L}^{-3}\right]$ and the solid phase (virus, bacteria) concentration $\left[N c \mathrm{M}^{-1}\right]$, respectively. Subscripts $e$ and 1 represent equilibrium and kinetic sorption sites. $N c$ is a number of microbial particles, and $\mu w$ and $\mu s$ represent inactivation and degradation processes (die-off) in the liquid and solid phases, respectively. $D^{w}{ }_{i j}$ is the dispersion coefficient for the liquid phase $\left[\mathrm{L}^{2} \mathrm{~T}^{-1}\right], \theta$ is the volumetric water content $\left[\mathrm{L}^{3} \mathrm{~L}^{-3}\right], \rho$ is the bulk density of porous medium $\left[\mathrm{ML}^{-3}\right]$, and $q$ is the specific discharge $\left[\mathrm{L} \mathrm{T}^{-1}\right]$. Mass transfer between the aqueous and solid phases can be described as in (Eq. 2):

$$
\rho \frac{\partial s}{\partial t}=\theta k_{a} c-k_{d} \rho s
$$

were $k_{a}$ is the first-order attachment coefficient $\left[\mathrm{T}^{-1}\right]$ and $k_{d}$ the first-order detachment coefficient $\left[\mathrm{T}^{-1}\right]$. According to Simunek [23], the attachment and detachment coefficients are strongly dependent upon the water content, with attachment significantly increasing as the water content decreases. Linear adsorption kinetics were assumed. The chemical non-equilibrium model was used with $50 \%$ of all sorption sites assumed to sorb instantaneously and the other $50 \%$ are governed by kinetic sorption. 
A 2D columnar hydraulic model domain was developed (Figure 1. 2) with three observation nodes at $4 \mathrm{~cm}, 14.5 \mathrm{~cm}$ and $25 \mathrm{~cm}$. The model geometry closely resembled the experimental set-up of the E.coli and MS-2 coliphage column experiments. That is, the model boundary on top of the flow domain was open to the atmosphere. The pulsed injections of microbial and conservative tracer (bromide) occurred into an initially unsaturated columnar environment. The bottom boundary was set at a fixed negative pressure head $-7 \mathrm{kPa}$ to simulate drainage into the unsaturated zone beneath. No-flux boundaries define the system along the column side boundaries. The flow and transport through the soil was modeled either with or without a $4-\mathrm{cm}$ thick biomat layer. The properties of the porous materials were obtained from the HYDRUS soil catalog [36]. Based on literature data, the diameter was set at $1.1 \mu \mathrm{m}$ for $E$. coli and $0.025 \mu \mathrm{m}$ for the MS-2 coliphage [37].

\section{RESULTS}

The bromide tracer test data and the code CXTFIT 2.1 was used to determine the column system dispersivity $(\lambda)$ for all three soils. Model fits were good with $\mathrm{R}^{2}$ values ranging from 0.97 to 0.99 . The dispersivity value calculated by CXTFIT 2.1 was approximately $0.289 \mathrm{~cm}$, which is typical for these types of experiments, and is consistent with the range of values $(0.06$ to $0.816 \mathrm{~cm})$ reported by others [38-43]. Next, the hydraulics of the HYDRUS model domain was calibrated using the conservative tracer breakthrough curves (BTC). The tracer test results were fitted for each of the three soil column depth intervals $(0-4 \mathrm{~cm}, 4-10.5 \mathrm{~cm}$, and $10.5-25 \mathrm{~cm})$. The data obtained at the 31 cm sample port was not fitted because E.coli and MS-2 phage concentrations were 
always below detection limit at that depth. The model results were plotted against the observed data (Figure 1.3).

The experimental bacterial transport data were fitted to HYDRUS utilizing the model's attachment/detachment module. The data were fitted in two steps: (1) inverse solution, keeping constant the STE and soil die-off rates values (Table 1.3), to determine the optimized attachment/detachment rates, and (2) a trial-and-error process in which dieoff and attachment/ detachments rates were modified simultaneously until an acceptable graphical fit was achieved. During the trial-and-error process, the emphasis was on achieving the best fit of the tailing end of experimental data. The best-fit simulations of the bacteria and virus test data from mesocosms are shown in Figure 1. 4 and 1.5 .

The experimental data and the model results were plotted both as normal-normal and lognormal graphs to emphasize the two principal phases of these experiments, i.e. the early, high concentration breakthrough and subsequent tailing phase characterized by low microbe concentrations. GFP E.coli concentrations were generally underestimated by the optimization simulation, while a fairly good fit was achieved by the trial-and-error procedure, particularly for the tailing phase. The normal-normal and log-normal plots of the modeled E.coli concentrations captured the oscillations caused by periodic dosing of the column system with STE. The measured bacteria data do not show these "oscillations" because the effluent sampling frequency was not sufficiently high to capture these changes. Initial and peak concentrations simulated at each sampling port and soil type tested are shown in Table 1. 4. As expected, the highest concentrations of bacteria and virus were measured at the beginning of the experiment. This breakthrough period is captured well by the model, as shown in the normal-normal graphs (Figures 1.4 
and 1.5). No breakthrough was observed at the depths greater than $14 \mathrm{~cm}$ for any of the $M S$-2 coliphage mesocosm experiments, except for the sandy soil. No differences were observed between the peak concentrations generated by the optimized model and the trial-and-error approach. At $4 \mathrm{~cm}$, for all soils, simulated peak concentrations (by trialand-error and optimization) show removal rates ranging from $45 \%$ to $84 \%$ for bacteria. At $25 \mathrm{~cm}$, for all soils, more than $99 \%$ of the added bacteria were removed. E. coli removal was greatest in the clay loam $(100 \%)$ and lowest in the sandy loam $(99.95 \%)$. In the case of MS-2 phage, removal was even higher, resulting in a reduction of $98.15 \%$ at 4 $\mathrm{cm}$, and near-detection limit concentrations at $14 \mathrm{~cm}$. Overall, simulated removal in all three soil types was consistent with the experimental data at all depths. MS-2 phage experimental data were not fitted for sandy loam and clay loam soils because the values recorded at $4 \mathrm{~cm}$ and $14 \mathrm{~cm}$ were below detection limit. "Only the few detects in sandy soil experiment were simulated (Figure 1. 7) and it is fully understood that showing MS-2 phage concentration $<1$ has only theoretical meaning. However, the simulation results demonstrate that the model was able to adequately capture the experimental results. Examination of the experimental data for the structured clay loam suggests that early breakthrough of the bacteria tracer occurred beneath the second $(14 \mathrm{~cm})$ sample port (Figure 1. 6). This suggests that the early breakthrough of E.coli is not linked to (bio)chemical transport phenomena, but rather must be caused by preferential flow conditions expected in a structured soil. Independent of the cause, the HYDRUS model could not adequately capture the early breakthrough in the clay loam soil. GFP E.coli and virus transport parameters obtained from the model through optimization and trial-anderror approaches are shown in Table 1. 5. The goodness-of-fit $\left(\mathrm{R}^{2}\right)$ of the model was 0.83 
or greater for the bacteria simulations, and $\mathrm{R}^{2}=0.76$ for the virus data. The nature of the graphical best-fit procedure precluded calculation of $\mathrm{R}^{2}$ values for the trial-and-error simulations. The liquid $\left(\operatorname{Sink}_{\mathrm{L}}\right)$ and solid (Sinks) phase GFP E. coli die-off rates in the optimization and trial-and-error simulations were generally within a factor of three of each other, except for Sinks for the clay loam soil, which varied by about an order of magnitude. Overall, the trial-and-error die-off rates tended to be lower than the measured values used in the optimization procedure. Lower trial-and-error die-off rates appeared to have been compensated for by attachment rates that were approximately 2 to 3 times greater than those obtained by optimization. In the case of the sandy soil attachment rate, the results from both estimation methods resulted in identical outcomes. By contrast, detachment rates were 37 to 74 times lower than attachment rates for trial-and-error and 1.3 to 37 times for the optimized simulation. The optimized detachment rate in clay loam soil indicates quasi-irreversible $\left(1 \times 10^{-7} \mathrm{~h}^{-1}\right)$ detachment of GFP E.coli. Overall, the combination of lower die-off rates and greater attachment rates resulted in a better capture of the tailing phase when using the trial-and-error procedure (log-log inserts in Figures 5 through 7).

Only the sand soil experiment produced sufficient breakthrough data to attempt a simulation of the virus data. The liquid phase die-off rate was about half of the solid phase die-off rate in case of the optimization procedure $\left(\mathrm{R}^{2}=0.76\right)$, but more than an order of magnitude greater for the trial-and-error simulation. On the other hand, the trial-anderror virus attachment and detachment rates were very different to each other, attachment rates were 2 orders of magnitude higher than detachment rates. Overall, the results 
indicate that virus attachment rates were more than an order of magnitude higher than those for bacteria, while bacteria and virus detachment rates were similar.

\section{DISCUSSION}

The bacteria die-off rates measured for the three soil types were different (Table 1. 5), which provides evidence for the effect of local environmental soil conditions on bacteria die-off rates [44]. Chao and Feng [45] studied the survival of E. coli HB101 strains added to a silt loam soil at $30^{0} \mathrm{C}$, resulting in die-off rates ranging from $0.04 \mathrm{~d}^{-1}$ to $0.20 \mathrm{~d}^{-1}$ $\left(0.0017 \mathrm{hr}^{-1}\right.$ to $\left.0.0083 \mathrm{hr}^{-1}\right)$. Powelson and Mills [46] reported E. coli die-off rates of $0.0259 \mathrm{hr}^{-1}$ and $0.0693 \mathrm{hr}^{-1}$ in sand columns under saturated and unsaturated conditions, respectively. E. coli isolated from STE collected from an OWTS near Lake Okareka, New Zealand, were investigated to elucidate microbial attenuation and transport through pumice sand aquifers [47]. The results of that study showed soil-attached E.coli die-off rates ranged from $2.59 \mathrm{hr}^{-1}$ to $4.47 \mathrm{hr}^{-1}$. These few studies suggest that solid phase bacteria die-off rates have to be determined under environmental conditions representative of the location where the construction a new OWTS system will be built.

The measured die-off rates reported here for all three soil types may be different from in situ rates where the soils were collected (Colorado, Georgia, Rhode Island). It is also likely that the liquid phase die-off rates differ among locations because of differences in the chemical, physical and biological properties of wastewater. For the trial-and-error simulations, both the solid and liquid phase die-off rates were treated as variables, whereas they were fixed to the measured values during the optimization procedure (Table 1. 5). The attachment/detachment rates were fitting variables in both procedures. Based on the assumption of potentially location-specific solid and liquid phase die-off rates, 
treating these rates as variables may be considered for the optimization procedure. A better fit could be obtained by treating the die-off rates as variables, particularly during the tailing phase of each experiment, further research is needed to confirm this approach.

Average attachment rates, derived from either optimization or trial-and-error procedures, were highest for the sandy soil $\left(0.163 \mathrm{~h}^{-1}\right.$ for $E$. coli, $0.91 \mathrm{~h}^{-1}$ for MS-2). This result was unexpected because higher attachment rates are typically reported for fine-grained clay materials, rather than sandy soils. In general, the intrinsic lower surface area of coarser soils should result in less adsorption of microbes compared to finer textured soils $[10,48,49]$. In addition, the smaller pores that are prevalent in fine-grained soils are more effective for mechanical filtration (straining) of microbes than those in coarser porous soils. Conversely, unsaturated soils tend to retain more microbes than saturated soils. That is, with decreasing water content, higher retention of bacteria and viruses in the soil has been observed [38,50-52]. Because the air-water interface increases at decreasing water content, the removal and retention of microbes in fine-grained, such as the clay loam, should be, at a given water content, greater than in granular soils $[38,52,53]$. In our study, the water content of the sand and sandy loam soils at the end of the experiment was lower (0.15 and $0.23 \mathrm{~g} / \mathrm{g}$, respectively), compared to the clay loam soil $(0.32 \mathrm{~g} / \mathrm{g}$; Table 2). Therefore, the higher air-water interface in the coarser soils could explain the higher attachment rates, since more water-free surface area is available to interact with the microorganisms. Measurements of the air-water interface area at different saturations in various soil materials would be necessary to confirm this proposition.

The effects of soil texture on microbial removal are expected to be different for bacteria and viruses. In our experiments, MS-2 phages were removed much more effectively than 
bacteria. Sandy loam and clay loam soils removed phages more extensively than sandy soil did. Two main mechanisms have been considered for pathogen removal in soil: (i) mechanical filtration and (ii) adsorption. For instance, Powelson et al. [13] investigated the fate and transport of a Salmonella phage in structured soils and found a reduction in virus concentration of about $60 \%$ to $90 \%$ in clay, clay loam and silt loam soils. In a review of the literature, Amador et al. [53] concluded that, although coarser textured soils tend to remove fewer bacterial pathogens than finer textured soils, the depth of treatment is important in order to obtain acceptable removal rates (close to 100\%). The authors suggest that, because preferential pathways are more common in large-grained, textured soils, these pathways facilitate the transport of microbes to deeper depths relative to fine textured soils. In addition, they suggest that the soil texture and depth of soil treatment are not well-correlated variables in virus removal, which is consistent with the hypothesis that virus removal occurs by adsorption processes rather than mechanical filtration. Virus removal by adsorption processes is in agreement with our results, where the model computed higher attachment rates for viruses than bacteria in sandy soil.

On average, the detachment rate for both bacteria and viruses in all soils was $1.6 \%$ of the attachment rate (Table 1. 5). The lowest detachment rate values were observed in the structured clay soil, which suggest that bacteria and virus attachment in those soils is practically irreversible. Under those conditions, detachment can be considered negligible. This is consistent with previous studies, which concluded that the attachment of microbes to soil particles is an irreversible process [24,54-56]. 


\section{CONCLUSION}

Modeling results showed only small differences between attenuation parameters (microbial attachment and detachment rates) obtained by optimization and trial-and-error simulation processes, i.e. results were generally within a factor of three of each other. The microbe detachment rates were about two orders of magnitude lower than the corresponding attachment rates. Low or negligible detachment rates suggest quasiirreversible adsorption of microbes to soil. GFP E.coli concentrations were generally underestimated by the optimization simulation, whereas a better fit was achieved by the trial-and-error procedure, particularly for the tailing phase of each experiment. In case of the liquid and solid phase GFP E.coli die-off rates, the results of the optimization and trial-and-error simulations were generally within a factor of three of each other. Overall, the combination of lower die-off rates and higher attachment rates resulted in a better description of the tailing phase when using the trial-and-error procedure.

In general, the fit obtained in the optimization process should improve when concentration of bacteria or virus is measured more frequently. In addition, the results of the E.coli and MS-2 phage die-off rate experiments support the findings by Foppen and Schijven [44] that these measurements should be ideally collected under in situ conditions of the sample location rather than under standard laboratory conditions. This change in procedure would contribute to a better understanding of the effects of the local conditions on the soils and the resulting degradation/attenuation of those microbes.

The experimental data for the structured clay loam suggests that early breakthrough of the bacteria occurred. Although the presence of preferential flow pathways in the mesocosms likely influenced the results, it is not possible to simulate those conditions 
with existing models. To better simulate the preferential flow effect on transport and fate of pathogenic contaminants in the soil it is necessary to evaluate the in situ spatial distribution of soil hydraulic properties. In the interim, a dual permeability model may be used to diversify the different flow patterns that might occur in the soil profile $[43,57$, 58]. Numerical modeling limitations were also evident when simulating the transport of microbes because the model neglects processes that intervene in the attenuation of microorganism in the field (i.e., straining, size exclusion).

\section{ACKNOWLEGMENTS}

This study was funded by a grant from the Water Environment Research Foundation (DEC1R06), by a U.S. Department of Agriculture (USDA) Multistate Project (NE 1045) and by funds from the Rhode Island Agricultural Experiment Station. We thank John McCray from the Colorado School of Mines (Golden, CO, USA) for MS-2 coliphage and sandy loam soil, and David Radcliffe from the University of Georgia (Athens, GA, USA) for clay soil. 


\section{REFERENCES}

1. U S Environmental Protection Agency. "Onsite Wastewater Treatment Systems Manual.” Environmental Protection. 2002, 1-367.

2. Canter, L. W., \& Knox, R. C. Septic Tank System Effects on Ground Water Quality. Lewis Publishers, Inc, 1985.

3. Gerba, C. P., \& Goyal, S. M. "Pathogen Removal from Wastewater During Groundwater Recharge." In Artifical Recharge of Groundwater. Butterworth Publishers, 1985.

4. Crites, R. W. "Micropollutant Removal in Rapid Infiltration.” In Artificial Recharge of Groundwater. Butterworth Publishers, 1985.

5. Sobsey, M. D., \& Shields, P. A. "Survival and Transport of Viruses in Soils." In Human Viruses in Sediments, Sludges, and Soils, 155-177. Boca Raton, FL: CRC Press, 1987.

6. Ausland, G, T. K. Stevik, J. F. Hanssen, J. C. Køhler, \& P. D. Jenssen. "Intermittent Filtration of Wastewater--Removal of Fecal Coliforms and Fecal Streptococci." Water Research. 2002, 36, 3507-3516,.

7. Potts, D., Gorres, J., Nicosia, E., \& Amador, J. "Effects of Aeration on Water Quality from Septic System Leachfields.” J. Environ. Qual. 2004, 33, 1828-1838 .

8. Goyal, S., \& C. Gerba. "Comparative Adsorption of Human Enteroviruses, Simian Rotavirus, and Selected Bacteriophages to Soils." Applied Environmental Microbiology. 1979, 32, 2, 241-247. 
9. Dowd, S E, S D Pillai, S Wang, \& M Y Corapcioglu. "Delineating the Specific Influence of Virus Isoelectric Point and Size on Virus Adsorption and Transport through Sandy Soils." Applied and Environmental Microbiology. 1998, 64, 405410 .

10. Sobsey, M. D., C. H. Dean, M. E. Knuckles \& R. A. Wagner. "Interactions and Survival of Enteric Viruses in Soil Materials." Applied and Environmental Microbiology. 1980, 40, 92-101.

11. Lance, J. C., \& C. P. Gerba. "Virus Movement in Soil During Saturated and Unsaturated Flow." Applied and Environmental Microbiology. 1984, 47, 335-337.

12. Powelson, D. K., \& C. P. Gerba. "Virus Removal from Sewage Effluents During Saturated and Unsaturated Flow through Soil Columns." Water Research. 1994, 28, $10,2175-2181$.

13. Powelson, D. K., \& J. R. Simpson. "Virus Transport and Survival in Saturated and Unsaturated Flow through Soil Columns." J Environ Qual. 1990, 19, 3, 396-401.

14. Kristiansen, R. "Sand Filter Trenches for Purification of Septic Tank Effluent: I. The Clogging Mechanism and Soil Physical Environment." Journal of Environmental Quality. 1981, 10, 3, 353-357.

15. Beal, C. D., E. A. Gardner, G. Kirchhof, \& N. W. Menzies. "Long-Term Flow Rates and Biomat Zone Hydrology in Soil Columns Receiving Septic Tank Effluent." Water Research. 2006, 40, 2327-2338.

16. Unc, A. A., \& M. J. Goss. "Movement of Faecal Bacteria through the Vadose Zone." Water, Air, and Soil Pollution. 2003, 149, 1-4, 327-337.

17. Cey, E. E, D. L. Rudolph, \& J. Passmore. "Influence of Macroporosity on Preferential Solute and Colloid Transport in Unsaturated Field Soils." Journal of Contaminant Hydrology. 2009, 107, 45-57. 
18. Harvey, R. W., N. E. Kinner, D. MacDonald, E. W. Metge, \& A Bunn. "Role of Physical Heterogeneity in the Interpretation of Small Scale Laboratory and Field Observations of Bacteria, Microbial-Sized Microsphere, and Bromide Transport through Aquifer Sediments." Water Resources Research. 1993, 29, 8, 2713-2721.

19. Pivetz, B. E., and T. S. Steenhuis. "Soil Matrix and Macropore Biodegradation of 2,4D.” Journal of Environment Quality. 1995, 24, 564.

20. Pivetz, Bruce E., Martin Alexander, Jason W. Kelsey, and Tammo S. Steenhuis. "A Procedure to Calculate Biodegradation During Preferential Flow through Heterogeneous Soil Columns.” Soil Science Society of America Journal. 1996, 60, 381.

21. Jiang, S., P. Liping, , G. D. Buchan, J. Simůnek, M. J. Noonan, \& M. E. Close. "Modeling Water Flow and Bacterial Transport in Undisturbed Lysimeters Under Irrigations of Dairy Shed Effluent and Water Using HYDRUS-1D." Water Research. 2010, 44, 1050-1061.

22. Šimůnek, J, M. T. Van Genuchten, \& M. Sejna. The HYDRUS Software Package for Simulating the Two-and Three-Dimensional Movement of Water, Heat, and Multiple Solutes in Variably-Saturated Media. Technical Manual, 2006.

23. Pang, L., \& J. Šimůnek. "Evaluation of Bacteria-Facilitated Cadmium Transport in Gravel Columns Using the HYDRUS Colloid-Facilitated Solute Transport Model." Water Resources Research, 2006, 42, 16.

24. Gargiulo, G., S. A. Bradford, J. Simunek, P. Ustohal, H. Vereecken, \& E. Klumpp. "Bacteria Transport and Deposition Under Unsaturated Flow Conditions: The Role of Water Content and Bacteria Surface Hydrophobicity." Vadose Zone Journal. 2008, 7, 406-419. 
25. Zhang, H., N. A. Nordin, \& M. S. Olson. "Evaluating the Effects of Variable Water Chemistry on Bacterial Transport During Infiltration." Journal of Contaminant Hydrology. 2013, 150, 54-64.

26. APHA, AWWA, and WEF. Standard Methods for the Examination of Water and Wastewater 20th Edition. Public Health, 1999.

27. Adams, M. H. “Bacteriophages.” In Bacteriophages, 592, 1959.

28. Schoenau, J., \& R. Karamanos. "Sodium Bicarbonate-Extractable P, K, and N. In Carter Ed. Soil Sampling and Methods of Analysis." Canadian Society of Soil Science. 1993, 51-58.

29. Doane, T., \& W. R. Horwath. "Spectrophotometric Determination of Nitrate with a Single Reagent." Analytical Letters. 2003, 36, 2713-2722.

30. Lepore, B., \& Barak, P. "A Colorimetric Microwell Method for Determining Bromide Concentrations." Soil Sci Soc. Am. J. 2009, 73, 1130-1136.

31. Toride, N., F. J. Leij, \& M. T. Van Genuchten. "The CXTFIT Code for Estimating Transport Parameters from Laboratory or Field Tracer Experiments." Res Rep, 1995, 1-138.

32. Pinheiro, L. B., M. D. Gibbs, G. Vesey, J. J. Smith, \& P. L. Bergquist. "Fluorescent Reference Strains of Bacteria by Chromosomal Integration of a Modified Green Fluorescent Protein Gene." Applied Microbiology and Biotechnology. 2008, 77, $1287-1295$. 
33. Turco, R. F. "Detection and Enumeration of Coliform Bacteria in Soil." In Methods of Soil Analysis: Microbial and Biochemical Properties, 145-159. Madison, WI, 1994.

34. Burt, R. "Soil Survey Laboratory Methods Manual." Soil Survey Investigations Report. 2004, 42, 735.

35. Van Genuchten, M. Th. "A Closed-Form Equation for Predicting the Hydraulic Conductivity of Unsaturated Soils." Soil Science Society of America Journal, 1980, $44,892-898$.

36. Prescott, L. M, D. A. Klein, \& John P Harley. Microbiology. Microbiology, 2002.

37. Torkzaban, S., Hassanizadeh, S. M., H. A. M. de Bruin, J. F. Schijven, \& A. M. de Roda Husman. "Virus Transport in Saturated and Unsaturated Sand Columns." Vadose Zone Journal, 2006, 5, 877-885.

38. Zhao, L., X. Ju, B. Li, K. Hu, H. Wang, \& Y. Wei. "Simulation of Bromide and Nitrate Leaching Under Heavy Rainfall and High-Intensity Irrigation Rates in North China Plain." Agricultural Water Management, 2010.

39. Zhang, Q., Hassanizadeh, S. M., Raoof, A., Genuchten, M. V., \& Roels, S. M. "Modeling Virus Transport and Remobilization During Transient Partially Saturated Flow." Vadose Zone Journal. 2012, 11, 2.

40. Safadoust, A., M.R. Mosaddeghi, A. Heydari, B. Gharabaghi, A.A. Mahboubi, P. Voroney, \& A. Unc. "Effect of Regenerated Soil Structure on Unsaturated Transport of Escherichia Coli and Bromide." Journal of Hydrology. 2012, 430-431, $80-90$.

41. Feighery, J., Mailloux, B. J., Ferguson, A. S., Ahmed, K. M., Geen, A., \& Culligan, P. J. "Transport of E. Coli in Aquifer Sediments of Bangladesh: Implications for 
Widespread Microbial Contamination of Groundwater." Water Resources Research. 2013, 49, 3897-3911.

42. Wang, Y., S. A. Bradford, \& J. Šimůnek. "Transport and Fate of Microorganisms in Soils with Preferential Flow Under Different Solution Chemistry Conditions." Water Resources Research. 2013, 49, 2424-2436.

43. Foppen, J. W. A., \& J. F. Schijven. "Evaluation of Data from the Literature on the Transport and Survival of Escherichia Coli and Thermotolerant Coliforms in Aquifers Under Saturated Conditions." Water Research. 2006, 40, 401-426.

44. Chao, W L, and R L Feng. "Survival of Genetically Engineered Escherichia Coli in Natural Soil and River Water." The Journal of Applied Bacteriology. 1990, 68, 319-325.

45. Powelson, D. K. \& Mills, A. L. "Transport of Escherichia Coli in Sand Columns with Constant and Changing Water Contents." Journal of Environment Quality. 2001, 30, 238-245.

46. Pang, L., M. Close, M. Goltz, L. Sinton, H. Davies, C. Hall, \& G. Stanton. "Estimation of Septic Tank Setback Distances Based on Transport of E. Coli and FRNA Phages." Environment International. 2004, 29, 907-921.

47. Moore, S. K., R. T. Garvin, \& E. James. "Nucleotide Sequence of the $\operatorname{argF}$ Regulatory Region of Escherichia Coli K-12.” Gene. 1981, 116, 119-132.

48. Pang, L., McLeod, M., Aislabie, J., Šimůnek, Close, M., \& Hector, R. "Modeling Transport of Microbes in Ten Undisturbed Soils Under Effluent Irrigation." Vadose Zone Journal. 2008, 7, 97-111. 
49. Jin, Y., Chu, Y., \& Li, Y. "Virus Removal and Transport in Saturated and Unsaturated Sand Columns." Journal of Contaminant Hydrology. 2000, 43, 111128 ,

50. Han, J., Y. Jin, \& C. S. Wilson. "Virus Retention and Transport in Chemically Heterogeneous Porous Media Under Saturated and Unsaturated Flow Conditions." Environmental Science \& Technology. 2006, 40, 1547-1555.

51. Pang, L., \& J. Šimůnek. "Evaluation of Bacteria-Facilitated Cadmium Transport in Gravel Columns Using the HYDRUS Colloid-Facilitated Solute Transport Model." Water Resources Research, 2006.

52. Chu, Y., Jin, Y., Baumann, T., \& Yates, M. "Effect of Soil Properties on Saturated and Unsaturated Virus Transport through Columns." J. Environ. Qual. 2003, 32, 6, 2017-2025.

53. Amador, J. A., J. A. Atoyan, T. Boving, D. Kalen, \& G. Loomis. Microorganisms. In Development of Quantitative Tools to Determine the Expected Performance of Unit processes in Wastewater Soil Treatment Units: Literature review, London, UK, IWA Publishing: 2-26 - 22-41, 2009.

54. Yao, K., M. T. Habibian, \& C. R. O'Melia. "Water and Waste Water Filtration: Concepts and Applications." Environmental Science \& Technology. 1971, 5, 11051112.

55. Rajagopalan, R., \& C. Tien. "Trajectory Analysis of Deep-Bed Filtration with the Sphere-in-Cell Porous Media Model.” AIChE Journal. 1976, 22, 3, 523-533.

56. Pieper, P, J., N. Ryan, R. W. Harvey, G. L. Amy, T. H. Illangasekare, and D. W. Metge. "Transport and Recovery of Bacteriophage PRD1 in a Sand and Gravel Aquifer: Effect of Sewage-Derived Organic Matter." Environmental Science \& Technology. 1997, 31,: 1163-1170. 
57. Jarvis, N. J. “A Review of Non-Equilibrium Water Flow and Solute Transport in Soil Macropores: Principles, Controlling Factors and Consequences for Water Quality.” European Journal of Soil Science. 2007, 58, 523-546.

58. Šejna, M., M. Th. Van Genuchten, \& J. Šimůnek. "Development and Applications of the HYDRUS and STANMOD Software Packages and Related Codes." Vadose Zone Journal, 2008, 7, 587-600. 


\section{TABLES}

Table 1. 1 Soil properties prior (initial, in bold) to septic tank effluent addition, and after biomat formation.

\begin{tabular}{llllll}
\hline $\begin{array}{l}\text { Textural } \\
\text { class }\end{array}$ & $\begin{array}{l}\text { Depth } \\
(\mathrm{cm})\end{array}$ & $\mathrm{pH}$ & $\begin{array}{l}\text { Total C } \\
(\mathrm{g} / \mathrm{kg} \text { soil })\end{array}$ & $\begin{array}{l}\text { Total N } \\
(\mathrm{g} / \mathrm{kg} \text { soil })\end{array}$ & $\begin{array}{l}\text { Water } \\
\text { content } \\
(\mathrm{g} / \mathrm{g} \\
\text { soil })\end{array}$ \\
\hline \hline Sand & Initial & $\mathbf{3 . 2}$ & $\mathbf{3 . 6}$ & $\mathbf{0 . 3}$ & - \\
& 4 & 6.8 & 3.5 & 0.3 & 0.15 \\
& 14 & 5.9 & 3.3 & 0.3 & 0.09 \\
& 24 & 5.9 & 2.5 & 0.1 & 0.09 \\
& 34 & 8.0 & 2.7 & 0.2 & 0.04 \\
Sandy loam & Initial & $\mathbf{6 . 0}$ & $\mathbf{1 2 . 9}$ & $\mathbf{1 . 1}$ & - \\
& 4 & 6.7 & 9.3 & 1.0 & 0.23 \\
& 14 & 6.7 & 9.9 & 0.9 & 0.21 \\
& 24 & 7.0 & 10.2 & 0.9 & 0.21 \\
& 34 & 7.1 & 10.7 & 1.0 & 0.14 \\
Clay loam & Initial & $\mathbf{4 . 2}-\mathbf{4 . 6}$ & $\mathbf{2 . 7 - 4 . 8}$ & $\mathbf{0 . 3 - 0 . 6}$ & - \\
& 4 & 6.0 & 5.4 & 1.0 & 0.32 \\
& 14 & 6.1 & 4.7 & 0.9 & 0.32 \\
& 24 & 5.7 & 2.7 & 0.8 & 0.30 \\
& 34 & 5.4 & 2.6 & 0.8 & 0.27 \\
\hline
\end{tabular}


Table 1. 2 Chemical and microbial properties of septic tank effluent (STE)

\begin{tabular}{llllllll}
\hline & $\begin{array}{l}\mathrm{BOD}_{5} \\
(\mathrm{mg} / \mathrm{l})\end{array}$ & $\mathrm{pH}$ & $\begin{array}{l}\text { Dissolved } \\
\mathrm{O}_{2} \\
(\mathrm{mg} / \mathrm{l})\end{array}$ & $\begin{array}{l}\text { Fecal } \\
\text { coliforms } \\
(\mathrm{cfu} / \mathrm{ml})\end{array}$ & $\begin{array}{l}\text { Coli- } \\
\text { phages } \\
(\mathrm{pfu} / \mathrm{ml})\end{array}$ & $\begin{array}{l}\text { Total P } \\
(\mathrm{mg} / \mathrm{l})\end{array}$ & $\begin{array}{l}\text { Total N } \\
(\mathrm{mg} / \mathrm{l})\end{array}$ \\
\hline Average & 224 & 6.82 & 0 & $2.93 \times 10^{3}$ & 0 & 6 & 30 \\
Max & 383 & 7.20 & 0 & $8.70 \times 10^{3}$ & 2 & 8 & 52 \\
Min & 45 & 6.43 & 0 & $1.00 \times 10^{2}$ & 0 & 2 & 0 \\
\hline$N$ & 35 & 36 & 23 & 32 & 32 & 33 & 33 \\
\hline
\end{tabular}


Table 1. 3 Measured GFP E. coli die-off rates in soil and septic tank effluent.

\section{Die-off rate $\left(\mathrm{hr}^{-1}\right)$}

\begin{tabular}{lll}
\cline { 2 - 3 } Medium & Measured & $\mathbf{R}^{\mathbf{2}}$ \\
\hline Sand & 0.0617 & 0.791 \\
Sandy loam & 0.0298 & 0.965 \\
Clay loam & 0.2476 & 0.965 \\
Septic tank effluent & 0.0824 & 0.891 \\
\hline
\end{tabular}


Table 1. 4 Modeled GFP E. coli and MS-2 phage peak concentrations for sandy, sandy loam, and clay loam soil using optimization or trial-and-error approaches. Values in parentheses are percent removal rates. The microbial tracers $\left(\mathrm{C}_{0}=\right.$ initial concentration $)$ were applied together with STE at a hydraulic loading rate of $2.4 \mathrm{~cm} /$ day every $12 \mathrm{~h}$ over 37 h. BD: below detection limit.

Peak concentration (cfu/ml)

\begin{tabular}{|c|c|c|c|c|c|c|}
\hline $\begin{array}{l}\text { Micro- } \\
\text { organism }\end{array}$ & Soil type & $\begin{array}{l}\mathrm{C}_{0} \\
(\mathrm{cfu} / \mathrm{mL})\end{array}$ & $\begin{array}{l}\text { Simulation } \\
\text { type }\end{array}$ & $4 \mathrm{~cm}$ & $14 \mathrm{~cm}$ & $25 \mathrm{~cm}$ \\
\hline \multirow{3}{*}{ E. coli } & Sandy & $1.0 \mathrm{E}+05$ & $\begin{array}{l}\text { Trial/Error } \\
\text { Optimized }\end{array}$ & $\begin{array}{l}5.42 \mathrm{E}+04 \\
(45.80) \\
5.46 \mathrm{E}+04 \\
(45.40)\end{array}$ & $\begin{array}{l}8.76 \mathrm{E}+02 \\
(99.12) \\
9.32 \mathrm{E}+02 \\
(99.07)\end{array}$ & $\begin{array}{l}1.35 \mathrm{E}+01 \\
(99.99) \\
1.53 \mathrm{E}+01 \\
(99.98)\end{array}$ \\
\hline & Sandy loam & $5.9 E+06$ & $\begin{array}{l}\text { Trial/Error } \\
\text { Optimized }\end{array}$ & $\begin{array}{l}2.45 \mathrm{E}+06 \\
(58.47) \\
2.60 \mathrm{E}+06 \\
(55.93)\end{array}$ & $\begin{array}{l}5.30 \mathrm{E}+04 \\
(99.10) \\
7.64 \mathrm{E}+04 \\
(98.71)\end{array}$ & $\begin{array}{l}1.46 \mathrm{E}+03 \\
(99.98) \\
2.74 \mathrm{E}+03 \\
(99.95)\end{array}$ \\
\hline & Clay loam & $5.9 \mathrm{E}+06$ & $\begin{array}{l}\text { Trial/Error } \\
\text { Optimized }\end{array}$ & $\begin{array}{l}1.02 \mathrm{E}+06 \\
(82.71) \\
9.36 \mathrm{E}+05 \\
(84.14)\end{array}$ & $\begin{array}{l}8.08 \mathrm{E}+02 \\
(99.99) \\
4.62 \mathrm{E}+02 \\
(99.99)\end{array}$ & $\begin{array}{l}\text { BD } \\
(100) \\
\text { BD } \\
(100)\end{array}$ \\
\hline \multirow{3}{*}{$\begin{array}{l}\text { MS-2 } \\
\text { Phage }\end{array}$} & Sandy & $1.0 \mathrm{E}+05$ & Trial/Error & $\begin{array}{l}1.85 \mathrm{E}+03 \\
(98.15) \\
2.38 \mathrm{E}+04 \\
(76.20)\end{array}$ & $\begin{array}{l}\text { BD } \\
(100) \\
\text { BD } \\
(100) \\
\end{array}$ & $\begin{array}{l}\text { BD } \\
(100) \\
\text { BD } \\
(100) \\
\end{array}$ \\
\hline & Sandy loam & $5.9 \mathrm{E}+06$ & $\begin{array}{l}\text { Trial/Error } \\
\text { Optimized }\end{array}$ & $\begin{array}{l}\mathrm{BD} \\
\mathrm{BD} \\
\end{array}$ & $\begin{array}{l}\mathrm{BD} \\
\mathrm{BD}\end{array}$ & $\begin{array}{l}\mathrm{BD} \\
\mathrm{BD} \\
\end{array}$ \\
\hline & Clay loam & $5.9 \mathrm{E}+06$ & $\begin{array}{l}\text { Trial/Error } \\
\text { Optimized }\end{array}$ & $\begin{array}{l}\mathrm{BD} \\
\mathrm{BD}\end{array}$ & $\begin{array}{l}\mathrm{BD} \\
\mathrm{BD}\end{array}$ & $\begin{array}{l}\mathrm{BD} \\
\mathrm{BD}\end{array}$ \\
\hline
\end{tabular}


Table 1. 5 E. coli and virus transport parameters derived from HYDRUS 2D/3D [23]. Non-detects of virus tracer in sandy loam and clay soils prevented modeling of these experiments.

\begin{tabular}{|c|c|c|c|c|c|c|c|}
\hline \multirow[b]{2}{*}{$\begin{array}{l}\text { Micro- } \\
\text { organism }\end{array}$} & \multirow[b]{2}{*}{ Soil type } & & \multicolumn{4}{|c|}{ Transport parameters } & \multirow[b]{2}{*}{$\mathbf{R}^{2}$} \\
\hline & & $\begin{array}{l}\text { Simulation } \\
\text { type }\end{array}$ & $\begin{array}{l}\operatorname{Sink}_{\mathbf{L}} \\
\left(\mathrm{hr}^{-1}\right)\end{array}$ & $\begin{array}{l}\text { Sinks } \\
\left(h^{-1}\right)\end{array}$ & $\begin{array}{l}\text { Attach } \\
\left(h^{-1}\right)\end{array}$ & $\begin{array}{l}\text { Detach } \\
\left(h r^{-1}\right)\end{array}$ & \\
\hline \multirow{6}{*}{ E. coli } & \multirow{2}{*}{ Sand } & Optimization & 0.0824 & 0.062 & 0.163 & 0.0044 & \multirow[t]{2}{*}{0.91} \\
\hline & & Trial/Error & 0.085 & 0.019 & 0.163 & 0.0023 & \\
\hline & \multirow{2}{*}{ Sandy loam } & Optimization & 0.0824 & 0.0298 & 0.026 & 0.0199 & \multirow[t]{2}{*}{0.83} \\
\hline & & Trial/Error & 0.0298 & 0.020 & 0.085 & 0.0023 & \\
\hline & \multirow{2}{*}{ Clay loam } & Optimization & 0.0824 & 0.2476 & 0.078 & 0.0000001 & \multirow[t]{2}{*}{0.99} \\
\hline & & Trial/Error & 0.020 & 0.036 & 0.133 & 0.0018 & \\
\hline \multirow{2}{*}{$\begin{array}{l}M S-2 \\
\text { Phage }\end{array}$} & \multirow{2}{*}{ Sand } & Optimization & 0.0271 & 0.0425 & 1.00 & 0.0064 & \multirow[t]{2}{*}{0.76} \\
\hline & & Trial/Error & 0.750 & 0.017 & 0.82 & 0.0040 & \\
\hline
\end{tabular}

$\operatorname{Sink}_{L}$, aqueous phase die-off rate (STE), $\boldsymbol{S i n k}_{S}$, solid phase die-off rate, Attach, attachment rate, Detach, detachment rate. 


\section{FIGURES}

Figure 1. 1 Schematic of experimental setup. Drawing is not to scale.

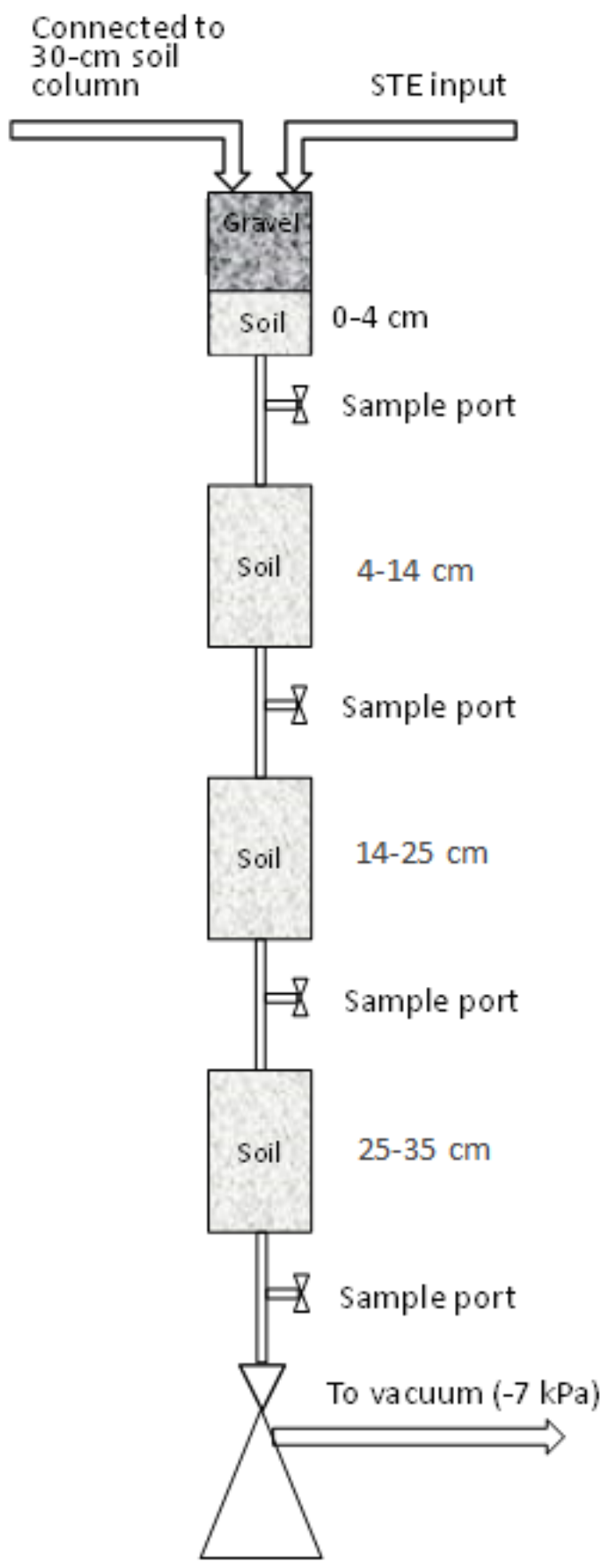


Figure 1. 2 Hydraulic model domain with (A) observation nodes at $4 \mathrm{~cm}, 14 \mathrm{~cm}$ and 25 cm depths, (B) boundary conditions.

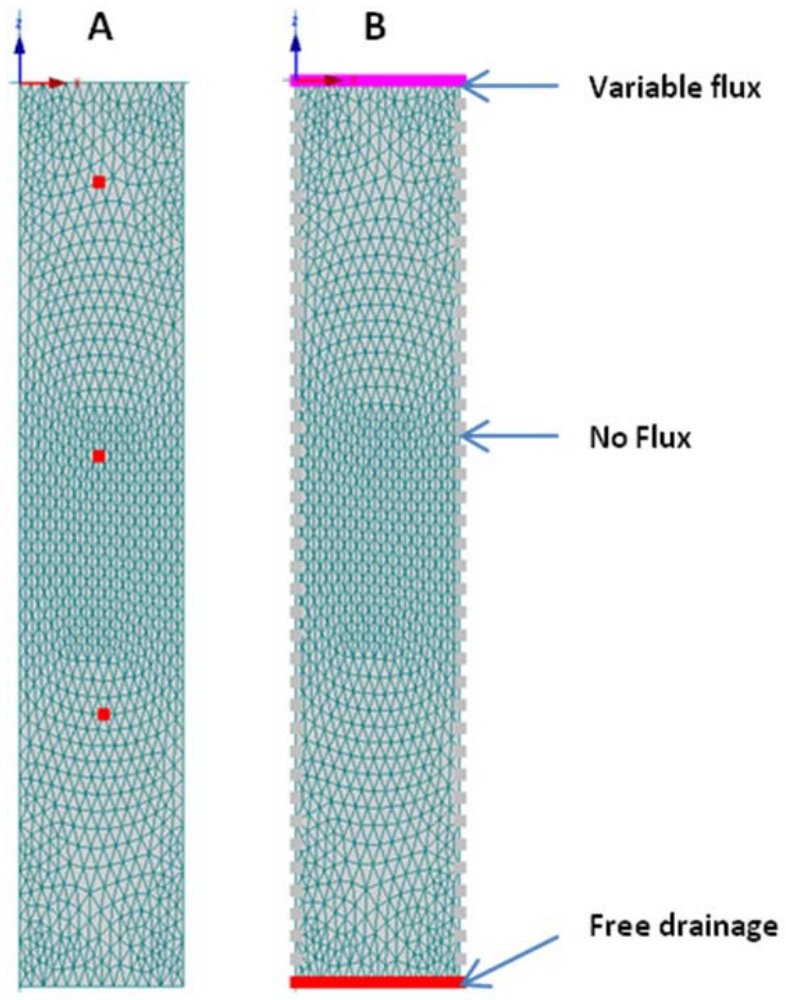


Figure 1. 3 Bromide tracer test results and best fit obtained for the three soil column depth intervals $(0-4 \mathrm{~cm}, 4-14 \mathrm{~cm}$, and $14-25 \mathrm{~cm})$ in sandy soil.

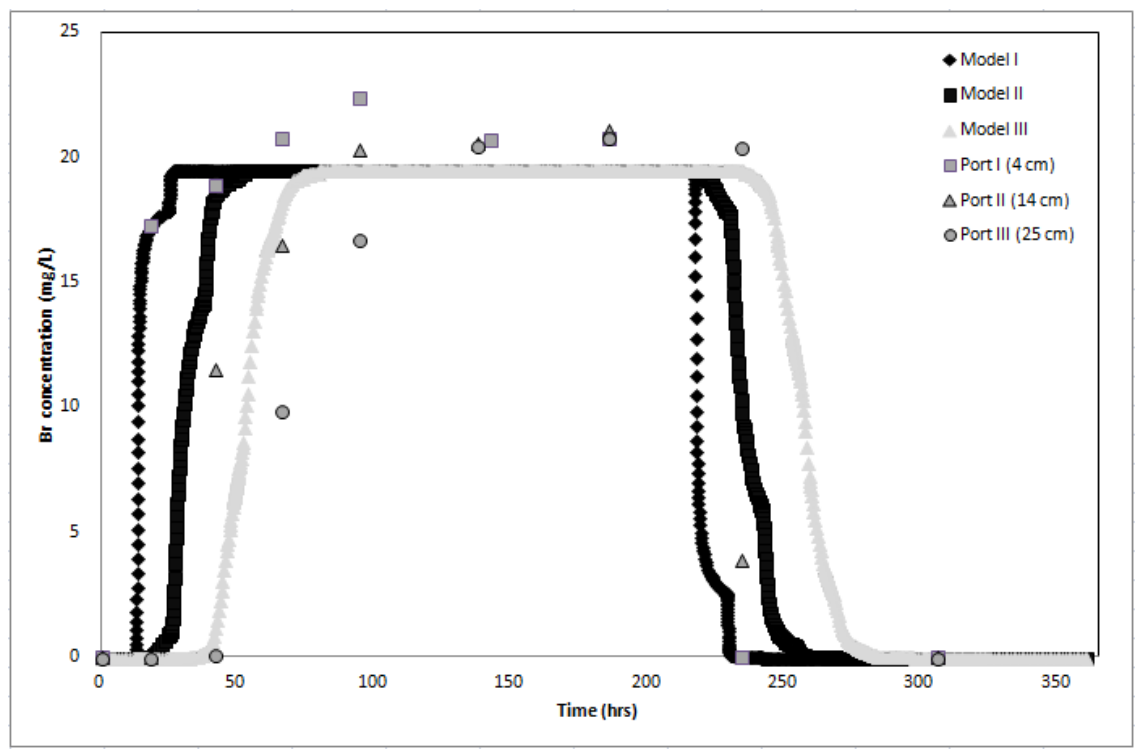


Figure 1. 4 Experimental GFP E. coli data and HYDRUS optimization (left) and trialand-error (right) simulation for the sandy soil at $4 \mathrm{~cm}, 14.5 \mathrm{~cm}$ and $25 \mathrm{~cm}$ depth. The lognormal inserts emphasize the tailing phase.
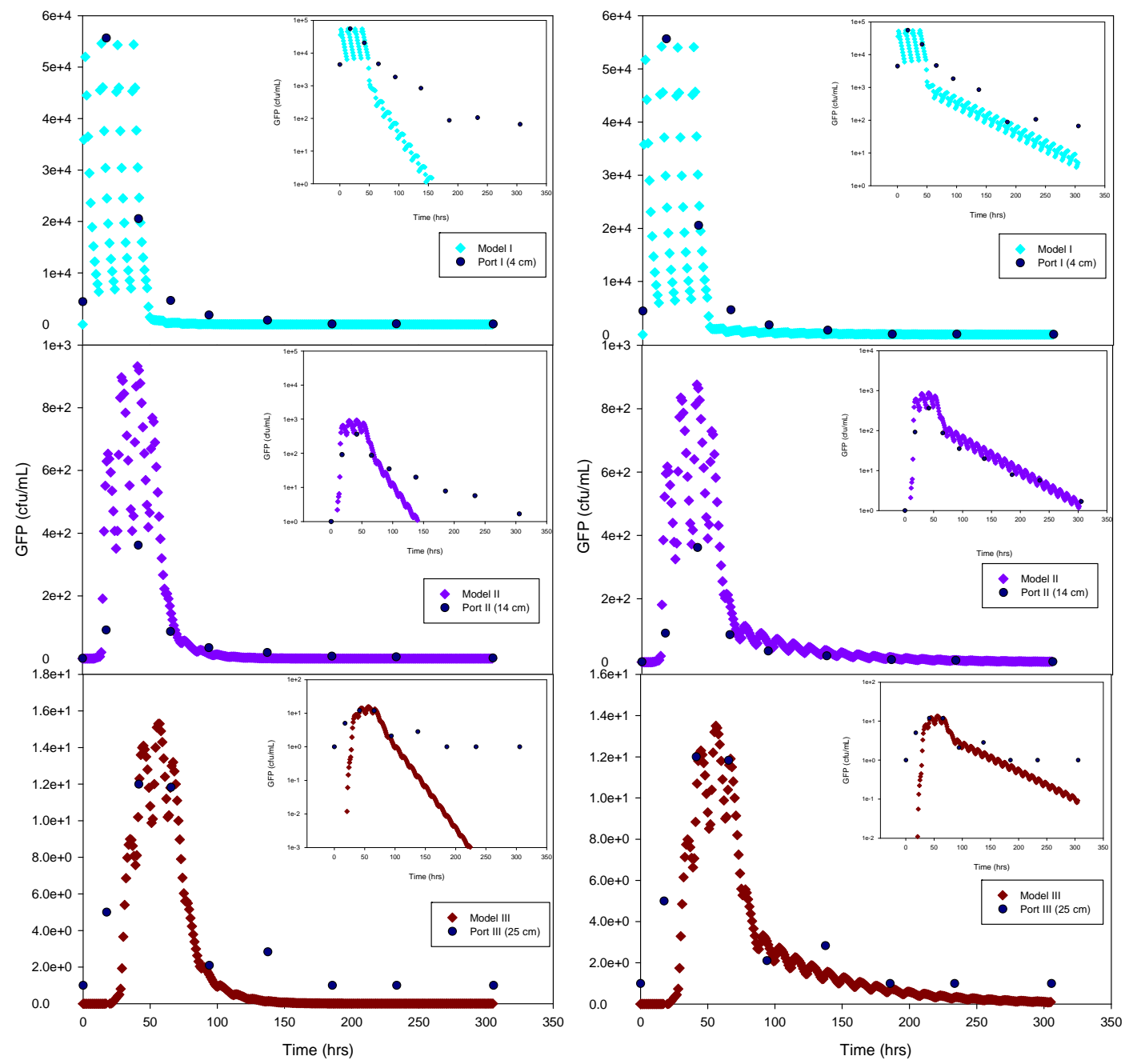
Figure 1. 5 Experimental GFP E. coli data and HYDRUS optimization (left) and trialand-error (right) simulation for the sandy loam soil at $4 \mathrm{~cm}, 14 \mathrm{~cm}$ and $25 \mathrm{~cm}$ depth. The log-normal inserts emphasize the tailing phase.
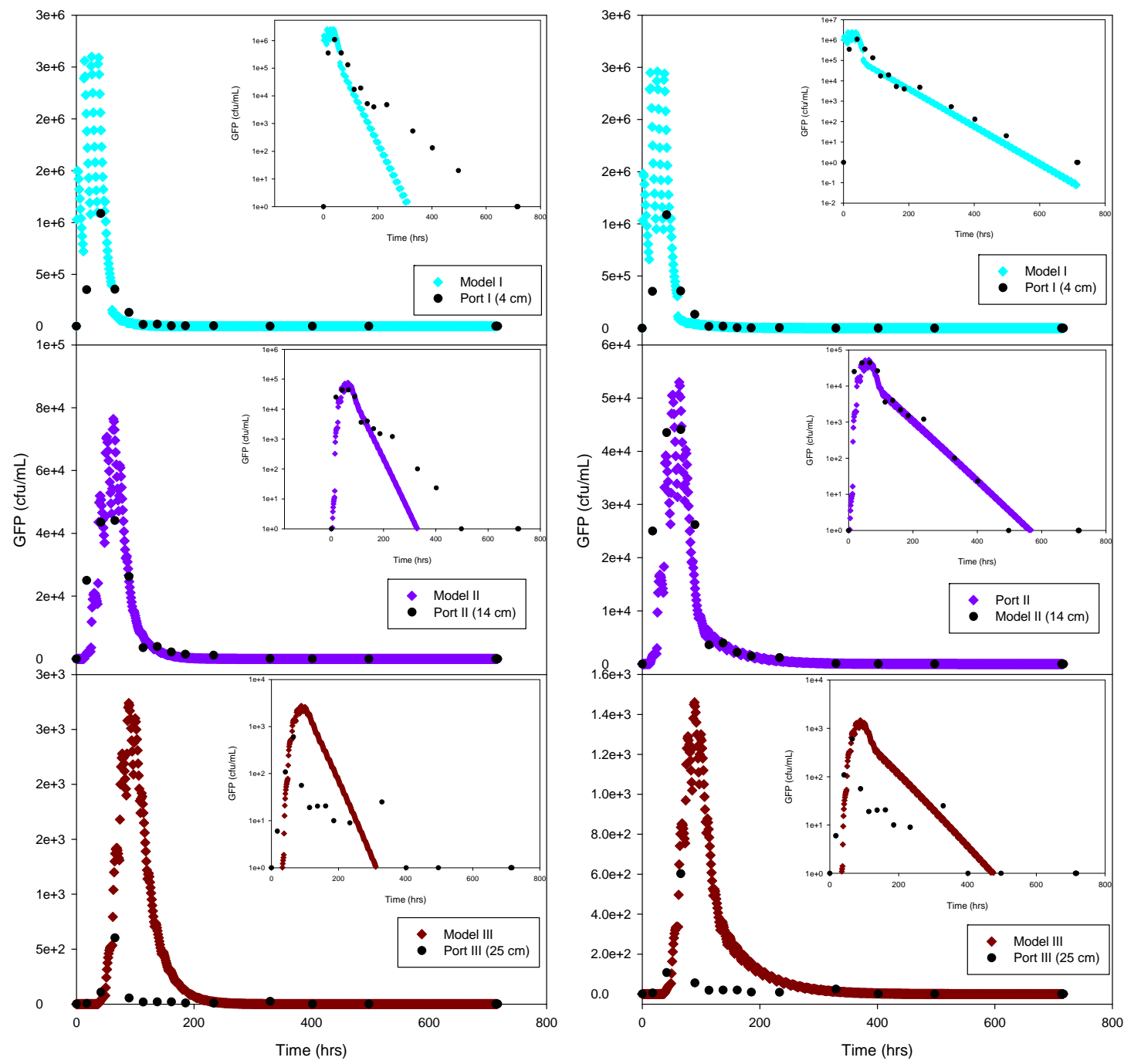
Figure 1. 6 Experimental GFP E. coli data and HYDRUS optimization (left) and trialand-error (right) simulation for the clay loam soil at $4 \mathrm{~cm}, 14 \mathrm{~cm}$ and $25 \mathrm{~cm}$ depth. The log-normal inserts emphasize the tailing phase.
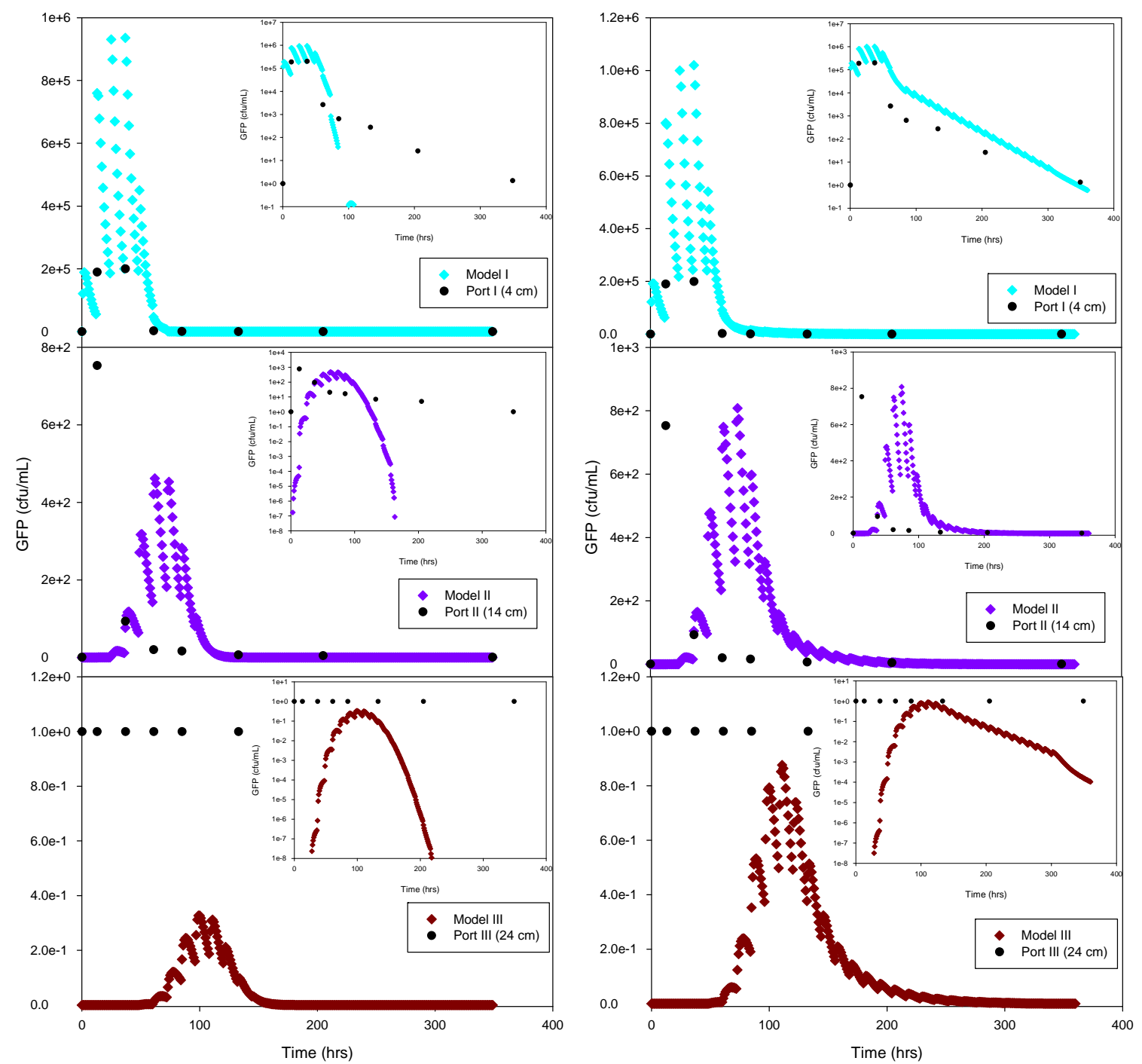
Figure 1. 7 Experimental MS-2 phage data and HYDRUS optimization (left) and trialand-error (right) simulation for the sandy soil at $4 \mathrm{~cm}, 14 \mathrm{~cm}$ and $25 \mathrm{~cm}$ depth. The lognormal inserts emphasize the tailing phase.
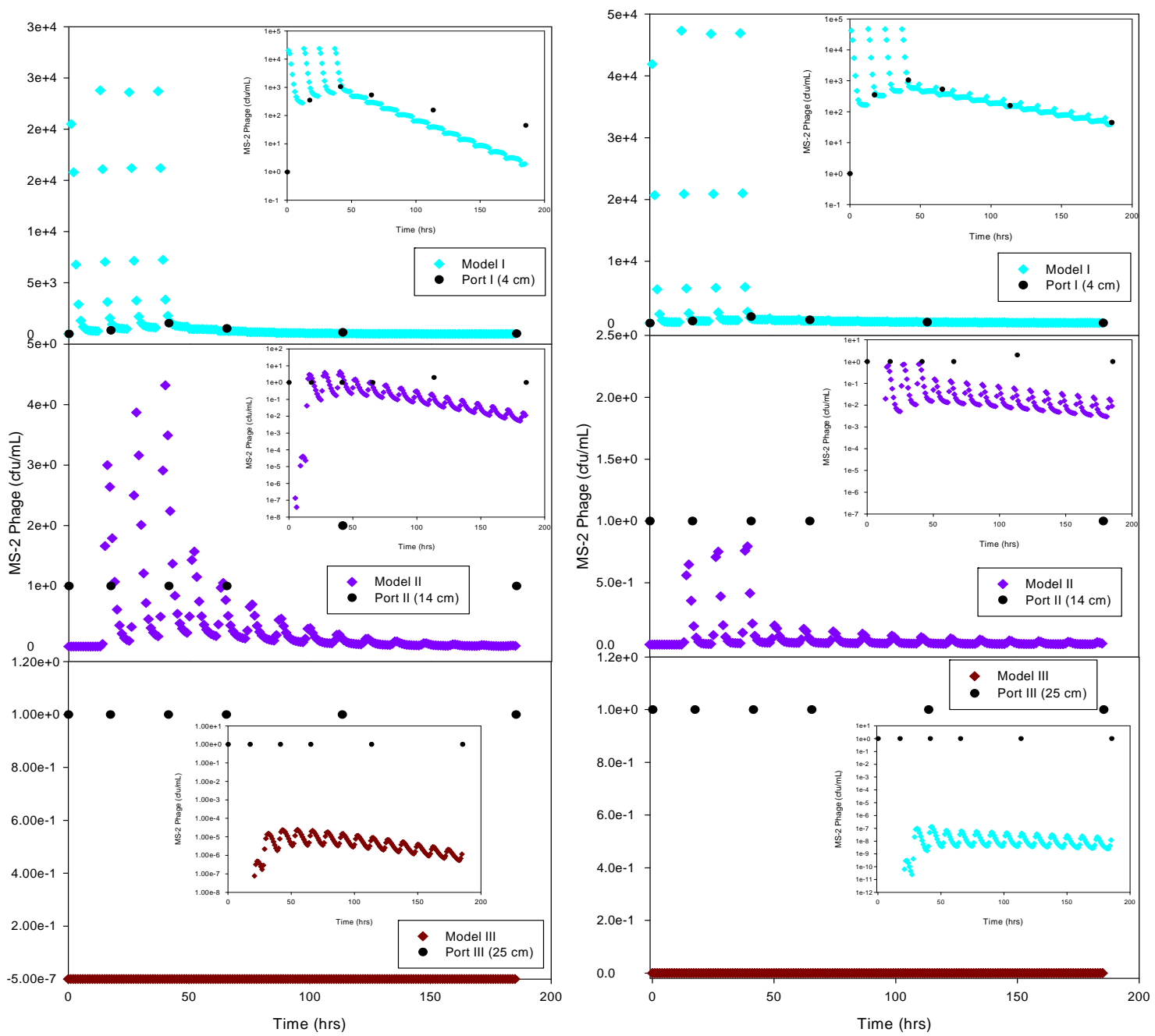
MANUSCRIPT - II: BACTERIA TRANSPORT IN A SOIL-BASED

WASTEWATER TREATMENT SYSTEM UNDER SIMULATED OPERATIONAL AND CLIMATE CHANGE CONDITIONS

Accepted for publication in Journal of Environmental Quality, June 2015

\author{
Ivan Morales ${ }^{1}$, José A. Amador ${ }^{2}$, Thomas Boving ${ }^{1,3 *}$ \\ ${ }^{1}$ Department of Civil and Environmental Engineering, ${ }^{2}$ Laboratory of Soil Ecology and \\ Microbiology, and ${ }^{3}$ Department of Geosciences, University of Rhode Island, Kingston, RI
}

*Corresponding author 


\begin{abstract}
Bacteria removal efficiencies in a conventional soil-based wastewater treatment system (OWTS) have been modeled to elucidate the fate and transport of $E$. coli bacteria under environmental and operational conditions that might be expected under changing climatic conditions. The HYDRUS 2D/3D software was used to model the impact of changing precipitation patterns, initial bacteria concentrations, hydraulic loading rates (HLR), and higher subsurface temperatures at different depths and soil textures. Modeled effects of initial bacteria concentration shows that greater depth of treatment was required in coarser soils than in fine textured ones to remove $E$. coli. The initial removal percentage was higher when HLR was lower, but it was greater when HLR was higher. When a biomat layer was included in the transport model, the performance of the system improved by up to $12.0 \%$. Lower bacteria removal (up to $5 \%$ ) was observed at all depths under the influence of precipitation rates ranging from $5 \mathrm{~cm}$ to $35 \mathrm{~cm}$, and $35 \mathrm{~cm}$ rainfall combined with a $70 \%$ increase in HLR. C Increased subsurface temperature due to climate change $\left(23{ }^{\circ} \mathrm{C}\right)$ increased bacteria removal relative to a lower temperature range $\left(5^{\circ} \mathrm{C}\right.$ to $\left.20^{\circ} \mathrm{C}\right)$. Our results show that the model is able to simulate bacteria removal, and the effect of precipitation and temperature in different soil textures effectively. It appears that the performance of OWTS may be impacted by changing climate.
\end{abstract}




\section{INTRODUCTION}

Soil-based onsite wastewater treatment systems (OWTS) are alternative technologies for wastewater management in areas where centralized wastewater treatment systems are neither suitable nor sustainable (Siegrist, 2001). It is estimated that $25 \%$ of U.S. households rely on OWTS for sewage treatment and disposal (U.S. EPA, 2002). Conventional OWTS consists of a pretreatment unit, or septic tank, an effluent distribution box, and a soil treatment area. The effluent distribution box is connected to a subsurface infiltration gallery or horizontal drain made from perforated pipes located in an excavated trench backfilled with gravel or crushed stone.

OWTS are a potential source of pathogenic bacteria and viruses, and they are one of the major causes of contamination and water quality impairments in surface water in U.S (US EPA, 2014). To avoid microbial contamination, U.S. EPA recommends a minimum separation distance of $45 \mathrm{~cm}$ between the infiltrative surface and the water table, regardless of soil chemical and physical properties (US EPA, 2002). Setback distances between OWTS and potential receptors, such as drinking water wells, are determined on a site-by-site basis. These variables have to be considered as well as differences in soil properties and OWTS loading rates that may influence soil treatment area (STA) performance. Projections of climate conditions in parts of the U.S., including the Northeast, indicate that sea level, rainfall rates and temperatures have been on the rise and will continue to do so over the next century (Kirtman et al., 2013). These climatic changes are expected to influence the performance of OWTS, since increased 
precipitation and sea level rise may lead to rising water tables and insufficient treatment depth, and higher temperatures are likely to change pathogen reduction rates.

As the septic tank effluent (STE) percolates through the STA, a combination of physical, chemical, and biological processes are involved in the removal of bacteria. The reduction of bacteria in STAs may be attributed to predation by bactrivorous organisms, mechanical filtration, adsorption, and changes in flow rate (Canter, 1985; Crites, 1985; Gerba, and Goyal, 1985; Sobsey and Shields, 1987). Soil texture and structure also have a significant effect on filtration and adsorption of bacteria. In general, fine-textured and poorly structured soils remove bacteria through mechanical filtration because of the smaller pore sizes and lower hydraulic conductivity (longer residence time) characteristic of these soils.

Bacteria removal is also influenced by the hydraulic loading rate, i.e. the volume of STE periodically applied to the STA. This variable inflow increases or decreases the degree of soil saturation and, as a result, affects the fluid-particle surface contact area and time (Huysman and Verstraete, 1993; McDowell-Boyer et al., 1986). Also, the hydraulic loading rate (Stevik et al., 1999) has a direct effect on bacteria transport. For instance, Huysman and Verstraete (1993) observed greater transport of bacteria in a series of column experiments when wastewater was applied at a flow rate of $4.7 \mathrm{~cm} \mathrm{~h}^{-1}$ compared to $0.8 \mathrm{~cm} \mathrm{~h}^{-1}$. High flow rates increase water movement through macropores and increase the displacement of bacteria (Thomas and Philips, 1979), which results in less interaction and shorter contact time between the bacteria and soil particles, therefore lowering adsorption rates (Lance and Gerba, 1984; Yates, 1988; Sharma et al., 1992). 
Intermittent infiltration of STE and the deposition of organic material results in the development of a low-permeability layer referred to as a biomat. A biomat develops at the infiltrative surface of the STA. In most systems, it extends as much as $2 \mathrm{~cm}$ below the water-soil interface and up the sidewalls of the STA trench (Kristiansen, 1981; Beal et al., 2006). Because of its relatively low permeability, the biomat layer is thought to enhance the removal of bacteria by reducing infiltration rates and favoring unsaturated conditions beneath the STA, as well as providing conditions advantageous for the biological decomposition of contaminants in the STE (Siegrist, 1987; US EPA, 2002). However, others consider the biomat to be detrimental, since it may cause drainfield clogging problems (Jarrett, 2014).

Other factors contribute to the retention and survival of bacteria in the STA. Ellwood et al. (1982) suggested that the rate of bacteria adsorption to soil particles increases linearly with bacteria concentration. A similar trend was found by Fletcher (1977) in an experiment measuring bacteria attachment to polystyrene. Temperature also plays an important role in the adsorption and survival of bacteria. At higher temperatures, more bacteria are adsorbed to soil particles and their survival decreases (Ostrolenk et al., 1947; Fletcher, 1977; Hendricks et al., 1979; Kristiansen, 1981; StenstrØm and Hoffner, 1982; Tamasi, 1981).

Computer simulations can help us understand the role of environmental conditions and quantify changes in bacteria inactivation. that allow us to examine removal and transport processes in soil with different texture and structure in response to changing environmental conditions, particularly by estimating survival and adsorption/desorption parameters (die-off rates in water and soil or 
attachment/detachment rates) (Šimůnek et al., 2006). A number of computer models have been used to simulate the fate and transport of bacteria in soil, including HYDRUS (Šimůnek et al., 2006), a commercially-available software package that simulates virus, bacteria and colloid transport processes in variably-saturated porous media (Jiang et al., 2010; Šimůnek et al., 2006; Pang and Šimůnek, 2006; Gargiulo et al., 2008; Zhang et al., 2013; Morales et al., 2014). The model includes a numerical solution for the Richards equation for variably saturated water flow and for advection-dispersion equations for heat and solute transport in one-, two- and three- dimensional domains. Pathogen transport processes are modeled based on attachment/detachment theory (Šimůnek et al, 2006; Jiang et al., 2010).

Removal of bacteria in soil is sensitive to water flow and content, as well as temperature. Climate change will bring about considerable changes in these properties over the next century. The objective of this study was to estimate bacteria removal efficiencies for a conventional OWTS under variable environmental (temperature, precipitation patterns, and presence of a biomat) and operational conditions (initial microbe concentration and hydraulic loading rate). The results of this study can help to guide practitioners in the design of effective OWTS under current and future warmer, wetter climatic conditions. 


\section{MATERIALS AND METHODS}

\section{Experimental setup}

Laboratory-scale mesocosm experiments were carried out previously to study the transport and fate of a model bacterium (GFP-E. coli) and measure the die-off rate constants for three soil/microbe systems (Amador and Atoyan, 2012). Briefly, three types of soil were used for this experiment, namely sandy, sandy-loam, and structured clay loam. For each soil, experiments were performed by dosing known quantities of aqueous phase E. coli onto a gravel layer on top of a soil column. The aqueous phase, spiked with GFP-E. coli, percolated through the gravel and the unsaturated soil. The gravel layer mimicked the aggregate fill of a typical OWTS trench. Bacteria concentrations were measured at three sample ports at $4 \mathrm{~cm}, 14 \mathrm{~cm}$ and $25 \mathrm{~cm}$ depth. Select physical and chemical properties of septic tank effluent and of the soils tested, including a detailed description of analysis methods, are summarized in Morales et al. (2014).

\section{Bacteria transport modeling and parameterization}

HYDRUS 2D/3D version 2.0 was used to simulate water flow and bacteria transport in soils under variably saturated conditions. The HYDRUS program numerically solves the Richards equation for saturated-unsaturated water flow (Eq. 1).

$$
\frac{\partial \theta}{\partial \mathrm{t}}=\frac{\partial}{\partial \mathrm{x}_{\mathrm{i}}}\left[\mathrm{K}\left(\mathrm{K}_{\mathrm{ij}}^{\mathrm{A}} \frac{\partial \mathrm{h}}{\partial \mathrm{x}_{\mathrm{j}}}+\mathrm{K}_{\mathrm{iz}}^{\mathrm{A}}\right)\right]-\mathrm{S}
$$

where $\theta$ is the volumetric water content $\left[\mathrm{L}^{3} \mathrm{~L}^{-3}\right], \mathrm{h}$ is the pressure head $[\mathrm{L}], \mathrm{S}$ is a sink term $\left[\mathrm{T}^{-1}\right]$, xi $(\mathrm{i}=1,2)$ are the spatial coordinates $[\mathrm{L}], \mathrm{t}$ is time $[\mathrm{T}], \mathrm{K}_{\mathrm{ij}}{ }^{\mathrm{A}}$ are components of 
a dimensionless anisotropy tensor $\mathrm{K}^{A}$, and $\mathrm{K}$ is the unsaturated hydraulic conductivity function $\left[\mathrm{LT}^{-1}\right]$ given by

$$
K(h, x, y, z)=K_{s}(x, y, z) K_{r}(h, x, y, z)
$$

where $K_{r}$ is the relative hydraulic conductivity and $K_{s}$ the saturated hydraulic conductivity $\left[\mathrm{LT}^{-1}\right]$. The model simulates virus and bacteria transport and fate processes based on a modified form of the advection-dispersion equation (Šimůnek et al., 2006) (Eq.3):

$$
\frac{\partial \theta C}{\partial t}+\rho \frac{\partial S_{e}}{\delta t}+\rho \frac{\partial S_{1}}{\partial t}+\rho \frac{\partial S_{2}}{\partial t}=\frac{\partial}{\partial t}\left(\theta D_{i j}^{w} \frac{\partial C}{\partial x_{j}}\right)-\frac{\partial q_{i} C}{\partial x_{i}}-\mu_{w} \theta C-\mu_{s} \rho\left(S_{e}+S_{1}+S_{2}\right)
$$

where $C$ and $S$ are the (virus, bacteria) solution concentration $\left[N c \mathrm{~L}^{-3}\right]$ and the solid phase (virus, bacteria) concentration $\left[N c \mathrm{M}^{-1}\right]$, respectively. Subscripts e, 1 and 2 represent equilibrium and kinetic sorption sites. $N c$ is the number of microbial particles, and $\mu_{w}$ and $\mu_{s}$ represent degradation processes (die-off) in the liquid and solid phases, respectively. $\mathrm{D}^{\mathrm{w}}{ }_{\mathrm{ij}}$ is the dispersion coefficient for the liquid phase $\left[\mathrm{L}^{2} \mathrm{~T}^{-1}\right], \theta$ is the volumetric water content $\left[\mathrm{L}^{3} \mathrm{~L}^{-3}\right], \rho$ is the bulk density of porous medium $\left[\mathrm{ML}^{-3}\right]$, and $q$ is the specific discharge $\left[\mathrm{LT}^{-1}\right]$. Mass transfer between the aqueous and solid phases can be described as in (Eq.4):

$$
\rho \frac{\partial S}{\partial t}=\theta k_{a} C-k_{d} \rho S
$$

where $k_{a}$ is the first-order attachment coefficient $\left[\mathrm{T}^{-1}\right]$ and $k_{d}$ the first-order detachment coefficient $\left[\mathrm{T}^{-1}\right]$. According to Šimůnek et al. (2006) and Gargiulo et al. (2008), the attachment and detachment coefficients are strongly dependent upon the water content, 
with attachment significantly increasing as the water content decreases. Linear adsorption kinetics were assumed. The chemical non-equilibrium model was used, with $50 \%$ of all sorption sites assumed to sorb instantaneously and the other $50 \%$ governed by kinetic sorption.

HYDRUS incorporates a modified equation of Walker (1974) to account for water content dependence:

$$
\mu(\theta)=\mu_{r} \theta_{r} \min \left[1,\left(\frac{\theta}{\theta_{r}}\right)^{B}\right]
$$

where $\mu_{r}$ is the values of a particular coefficient (rate constant) at the reference water content, $\theta_{r}, \mu$ is the value at the actual water content $\theta$, and $B$ is a solute dependent parameter (usually 0.7 ). The reference water content, $\theta_{r}$, which may be different for different soil layers, is calculated from the reference pressure head, $h_{r}$, which is considered to be constant for a particular compound.

The die-off rates and transport parameters were first determined from mesocosm experiments and fitted using the inverse solution algorithm included in the HYDRUS model (Morales et al., 2014). These parameters were then imported into a model that simulated a conventional OWTS trench with intermittent dosing (Fig. 1A). The trench model consisted of three materials. Material 1 was one of the three soils used in the transport experiments (sandy, sandy-loam, and structured clay loam). Material 2 was gravel or crushed stone backfill into which a horizontal drain or perforated pipe (i.d. $=10$ $\mathrm{cm}$ ) is embedded. The bottom of the pipe rests $15 \mathrm{~cm}$ above Material 3, which was a biomat layer with a thickness of $2 \mathrm{~cm}$. The bottom of the biomat is $88 \mathrm{~cm}$ above the 
bottom of the unsaturated zone, which is approximately twice the required minimum distance $(45 \mathrm{~cm})$ between the infiltrative surface and the water table (US EPA, 2002). This layer was assumed to extend up the sidewall to the average height of STE ponding in the trench, about $6 \mathrm{~cm}$, and was the biomat was assumed to be fully developed in the bottom and walls of the trench.

The HYDRUS model predicts the unsaturated hydraulic properties from surrogate soil data, such as soil textural class and bulk density (Rosetta Lite program, Schaap et al., 2001). This program uses pedotransfer functions (PTFs) based on neural networks to predict van Genuchten (1980) water retention parameters and the saturated hydraulic conductivity based on the textural information. The Rosetta-generated values were selected as the Material 1 properties, and were assumed to be constant and not affected by clogging or other changes that could occur over the lifespan of the trench system (Table 2. 1).

A finite-element mesh with 2326 nodes was used (Figure 2. 1.A) with minimum and maximum mesh sizes of $1.5 \mathrm{~cm}$ and $4.8 \mathrm{~cm}$, respectively. For faster model run times, it was assumed that the model domain is axi-symetric about the trench center line, with the axis of symmetry being a no-flux boundary. The opposing vertical side of the model domain is located $120 \mathrm{~cm}$ from the center of the pipe and it was treated as a no-flux boundary. In order to mimic intermittent STE dosing, a variable flux boundary was assigned to the embedded pipe. In the model, the STA was dosed twice daily for one hour at a rate of $0.424 \mathrm{~cm} \mathrm{~h}^{-1}$ every 12 hours. Steady state water flow conditions were reached after 30 days. 
The top of the model domain was treated as an atmospheric boundary (Figure 2. 1.B). Atmospheric boundary conditions allow HYDRUS users to simulate precipitation and evapotranspiration at the soil surface. This feature is based on a time-variable boundary condition, in which user-specified precipitation rates can be used as input data. This approach permits simulation of atmospheric inputs together with STE infiltration and simultaneous modeling of transport through the porous media. HYDRUS 2.0 also calculates a water balance for that interface. That information was used to identify the potential for surface runoff formation during simulations of precipitation events. The minimum allowed pressure head at the soil surface was $-10,000 \mathrm{~cm}$.

The initial soil pressure head and temperature conditions were set to $-100 \mathrm{~cm}$ and $20{ }^{\circ} \mathrm{C}$ over the model domain, respectively. Free drainage was assigned as the outflow boundary condition at the bottom of the model domain, where the groundwater level was assumed to be located at an undefined depth below the soil profile. The model was then run under steady state flow conditions. The response of the trench model to environmental stresses scenarios was examined at 14 observation points distributed beneath the pipe and $5 \mathrm{~cm}$ from trench sidewall at different depths $(10 \mathrm{~cm}, 17 \mathrm{~cm}, 23.3 \mathrm{~cm}, 28 \mathrm{~cm}, 42 \mathrm{~cm}, 70 \mathrm{~cm}$, and $105 \mathrm{~cm}$ ) (Figure 2. 1.C).

\section{Simulated Scenarios}

The trench model was run under various environmental stresses and operational conditions to predict the response of bacteria removal and attenuation capacity in the STA. The simulated scenarios varied: (1) effect of soil texture, (2) soil hydraulic properties, (3) operational hydraulic loading rates (HLR), and (4) soil temperature. The $E$. coli concentration in STE is $10^{5} \mathrm{cfu} \mathrm{mL}^{-1}$ (McCray et al., 2009) and was identical to the 
initial concentration in the mesocosm experiments from which much of the experimental data were derived (Amador et al., 2012; Morales et al., 2014). Some removal processes (i.e. mechanical filtration and adsorption) are affected by soil texture and structure. Therefore, the simulated trench was modeled for sand, sandy loam and clay loam soils in order to evaluate OWTS performance with respect to E. coli removal.

Observations in the field (Siegrist et al., 2004) and laboratory mesocosm experiments (Amador et al., 2012) indicate that biomat growth is most dominant at the bottom and the sidewalls of a treatment system. As the biomat develops, the hydraulic conductivity of the material decreases with time. A less conductive biomat increases the height of STE ponding in the trench, which increases the flow of wastewater through the sidewalls (Keys et al., 1998). To simulate the response of decreasing hydraulic conductivity of the biomat layer (Material 3; Figure 2. 1.A), its initial value was reduced by factors of 10 and 100 in the soil matrix, respectively. In order to simulate a more conductive biomat or a material with an increasing hydraulic conductivity in our model, this property was increased by 5 times compared to initial values (Table 2. 2).

An operational hydraulic loading rate of $0.424 \mathrm{~cm} \mathrm{hr}^{-1}$ at the trench bottom was chosen. This HLR is equivalent to about $3 \mathrm{~cm} \mathrm{day}^{-1}$ at the pipe level, which is the typical amount of STE applied to the STA in a conventional OWTS. Because the hydraulic loading rate varies over the lifetime of an OWTS, a range of $50 \%$ lower to $170 \%$ higher HLR was simulated $\left(0.212,0.424,0.530,0.635\right.$ and $\left.0.720 \mathrm{~cm} \mathrm{hr}^{-1}\right)$.

The STA also receives percolating water from precipitation and/or irrigation events. This additional input of water from the surface may influence the overall 
performance of the treatment system: e.g. enhanced infiltration may cause bacteria to be transported faster and possibly deeper into the subsurface (Shadford et al., 1997). To investigate the effect of external water inputs on the treatment, various infiltration events were simulated over a 17.5-day period (Table 2.3).

Finally, the effect of a changing temperature was evaluated. For initial conditions, the trench was modeled at $20{ }^{\circ} \mathrm{C}$ and the temperature was increased or decreased (range: $5^{\circ} \mathrm{C}$ to $23{ }^{\circ} \mathrm{C}$ ) to assess the effects of seasonal changes and/or climate changes on the survival of bacteria. Ambient temperature in the U.S. is expected to increase between $2-5^{\circ} \mathrm{C}$ during the next 100 years as a result of climate change (IPCC, 2013).

\section{Solute transport characteristics}

The hydraulic flow domain was approximated with bromide $\left(\mathrm{Br}^{-}\right)$tracer tests from which the hydraulic solute transport parameters in each of the three soils were determined. The results of these experiments are summarized in Morales et al. (2014). The longitudinal dispersivity $\left(\lambda_{\mathrm{L}}\right)$ was set to be one tenth of the soil profile depth beneath the pipe (Gelhar et al., 1992; Vanderborgt, J. and H. Vereecken , 2007). To mimic solute diffusion, the aqueous diffusion coefficient of $\mathrm{Br}^{-}$was used $\left(D_{o}=1.83 \times 10^{-5} \mathrm{~cm}^{2} \mathrm{sec}^{-1}\right)$ (Weast, 1985). For each of the three soils and for the STE, the E. coli die-off rates determined by Morales et al. (2014) were adopted (Supplemental Tables S1 and S2).

\section{Temperature dependence}

HYDRUS accounts for temperature dependence of transport and reaction rates by using a modified Arrhenius equation (Stumm and Morgan, 1981; Šimůnek et al., 2006 ): 


$$
a_{T}=a_{r} \exp \left[\frac{E_{a}\left(T^{A}-T_{r}^{A}\right)}{R_{u} T^{A} T_{r}^{A}}\right]
$$

where $a_{r}$ and $a_{T}$ are the values of the coefficient being considered at a reference absolute temperature $T_{r}^{A}$ and absolute temperature $T^{4}$, respectively; $R_{u}$ is the universal gas constant, and $E_{a}\left[\mathrm{ML}^{2} \mathrm{~T}^{-2} \mathrm{M}^{-1}\right]$ is the activation energy of the particular reaction. Bacteria die-off rates in water and attached to soil particles may be influenced by temperature (Bogosian et al., 1996; Wang and Doyle, 1998; Foppen and Schijven, 2006). Similarly, the attachment/detachment rates are considered a function of temperature (Hendricks et al., 1979; Stevik et al., 2004). Hence, the coefficients $a_{r}$ and $a_{T}$ in Eqn. 5 represent the temperature dependency of bacteria die-off and attachment/detachment rates, respectively, which link Eqn. 5 to the transport and mass transfer Eqns. 3 and 4. Finally, for this study, activation energies for survival of bacteria in soil and STE were set to 200,000 J Mol-1 (Bailey and Ollis, 1987; Szewczyk and Myszka, 1994). Unless stated otherwise, the model's physical parameters, such as diffusion coefficients, were based on standard conditions defined at $20^{\circ} \mathrm{C}$. Temperature dependence of soil hydraulic properties was not considered.

\section{Calibration and Validation}

The model was calibrated utilizing the bacteria transport data obtained in previous laboratory mesocosm experiments (Amador et al., 2012) and by incorporating the HYDRUS attachment/detachment module (Šimůnek et al., 2006). The data were fitted by HYDRUS 2D/3D inverse solution modeling. The fit was achieved by keeping constant the STE and soil die-off rates values (Table 1 and 2, supporting information). The model was 
not validated because only one data set for each soil type was obtained from the mesocosm experiments described in Morales et al. (2014). Validation against data from other studies was not considered because of differences in the soil media and experimental conditions.

\section{RESULTS AND DISCUSSION}

\section{Soil Texture}

We simulated how a trench system responds to sand, sandy loam and clay loam as native soil in the drainfield. The initial E. coli concentration in STE was $10^{5} \mathrm{cfu} \mathrm{mL}^{-1}$. The results showed that the bacteria concentration was significantly reduced $(99.99 \%$ reduction) in the first $30 \mathrm{~cm}$ of soil in the sandy and clay loam (Figure 2. 2a and b). Similar results were observed for the sandy loam, except that a greater soil depth was required to reduce bacteria below $1 \mathrm{cfu} / 100 \mathrm{ml}$. Deeper bacteria movement occurs in the sandy loam due to lower solid phase die-off and attachment rates than those in the sandy and clay loam soils (Supplemental table S2). For example, the sandy soil has die-off and attachment rates that are 2.08 and 6.27 times higher, respectively than the sandy loam. Hence, in sandy loam, fewer bacteria are removed and attached to the soil grains, which allows them to travel deeper through the soil profile.

The high adsorption of bacteria on the sand may be attributed to the lower simulated average water content (Sand, $0.080 \mathrm{~cm} \mathrm{~cm}^{-1}$; sandy loam, $0.1641 \mathrm{~cm} \mathrm{~cm}^{-1}$; clay loam, $\left.0.3729 \mathrm{~cm} \mathrm{~cm}^{-1}\right)$. The system was effective in removing bacteria in all soil textures directly below the trench or along a vertical profile cross-section a 5-cm lateral distance 
away from the trench sidewall and Bacteria were not detected at a depth of $23 \mathrm{~cm}$ (Figure 2. 2a and b).

These results indicate that $E$. coli removal is $>99.99 \%$ within the first $42 \mathrm{~cm}$ of treatment depth in all soils, and E. coli removal was complete at $70-\mathrm{cm}$ depth (data not shown). Increased removal with depth was even more pronounced farther away from the trench sidewall (Figure 2b). These results are consistent with other studies in which the removal efficiency of fecal bacteria in the STA was investigated in relation to soil texture and depth (e.g. Karathanasis et al., 2006; Amador et al., 2009). The positive correlation between bacteria removal and depth points to mechanical filtration (straining) processes that accumulate with increasing depth, especially in finer-textured soils (Keswick and Gerba, 1980; Powelson et al., 1990). Finer-textured soils have smaller pores and have a lower hydraulic conductivity, which promotes the mechanical filtration of bacteria and attachment. In addition, our model results reflect that the intrinsic lower specific surface area of coarser soils results in less adsorption of microbes compared to finer textured soils (Sobsey, 1980; Moore et al., 1981; Pang et al., 2008). The clay loam soil showed higher adsorption, and almost no detachment occurred (attachment/detachment coefficients, Supplemental Table S2), indicating that the soil particles have a greater level of physical interaction with microbes (due to a high specific surface area), and thus more bacteria are retained and removed on the particle surface.

\section{Hydraulic Loading Rate}

A range of $50 \%$ lower to $170 \%$ higher HLR was modeled (initial HL of $0.424 \mathrm{~cm}$

$\mathrm{h}^{-1}$ ) and the effluent $E$. coli concentrations were recorded at observation nodes located along two vertical profile cross-sections (Figure 2. 3a and b). At shallow depth $(10 \mathrm{~cm})$, 
and directly beneath the trench, the STA removed $10 \%$ more the HLR was low $(0.212 \mathrm{~cm}$ $\left.\mathrm{h}^{-1}\right)$ relative to a higher HLR $\left(0.72 \mathrm{~cm} \mathrm{~h}^{-1}\right)$. At a greater depth $(17 \mathrm{~cm})$, more than $90 \%$ of bacteria were removed in all three soil types, independent of HLR. These results indicate that, although the initial removal percentage was lower when the HLR was higher, the rate of removal increased with depth. The relatively lower reduction in E. coli concentration at higher HLR is attributed to a decrease in the average water suction of the unsaturated porous media and increases of the transport of bacteria through larger pores, which reduces the effect of bacterial straining by soil (Bouma, et al., 1974; Thomas et al., 1979; Smith et al., 1985). Overall, the soil removed E. coli more than $99.99 \%$ even at the highest simulated loading rate. The reduction was $99.99 \%$ at $42-\mathrm{cm}$ depth on both observation profiles (Figure 2. 3a and b), with the most efficient removal in the finest textured soil (clay loam).

Design HLR is used to determine the size of the infiltrative surface in a conventional OWTS trench. This parameter provides the STA with adequate organic loadings and re-aeration conditions for chemical and biological treatment of contaminants (US EPA, 2002). Radcliffe and West (2009) developed a method for estimating the design HLR based on soil texture and hydraulic properties using a two-dimensional HYDRUS model. The steady flux through the trench bottom for the 12 USDA soil textural classes was simulated with $5 \mathrm{~cm}$ of wastewater ponded in the trench. The design HLR was estimated by accounting for $50 \%$ of the steady trench bottom flux as a safety factor. For sand, sandy loam and clay loam, the estimated design HLR was 0.182, 0.126 and $0.084 \mathrm{~cm} \mathrm{~h}^{-1}\left(4.37,3.03\right.$ and $\left.2.02 \mathrm{~cm} \mathrm{day}^{-1}\right)$, respectively. In our study, based on the reduction of $E$. coli, the optimal design HLR was $0.212 \mathrm{~cm} \mathrm{~h}^{-1}$ for all three soils, slightly 
above the values reported by Radcliffe and West (2009). Siegrist (2007) proposed a design HLR method that depends on the type of wastewater treatment system and soil textural class. For a conventional OWTS trench, our optimal design HLR value is slightly higher than those suggested by Siegrist (2007) for sand $\left(0.167 \mathrm{~cm} \mathrm{~h}^{-1}\right)$, sandy loam $(0.083$ $\left.\mathrm{cm} \mathrm{h}^{-1}\right)$ and clay loam $\left(0.021 \mathrm{~cm} \mathrm{~h}^{-1}\right)$.

\section{Presence of a Biomat}

The development of a biomat layer is expected to change the flow pattern in the soil and at the infiltrative surface. The expected reduction in hydraulic conductivity, from pore clogging and pore size restrictions (Stevik et al., 2004), should increase the retention time of wastewater as it percolates through the soil. A longer residence time should provide better treatment. In our model (Figure 2. 1), the biomat was simulated as a 2-cmthick layer at the bottom and the trench sidewall, with variable hydraulic conductivity values ranging from 0.000017 to $0.0085 \mathrm{~cm} \mathrm{hr}^{-1}$.

The results showed that under lower hydraulic conductivity conditions, slower infiltration of wastewater in the STA resulted in greater bacteria removal (Figure 2. 4a and b). For example, at $28-\mathrm{cm}$ depth, more than $99 \%$ of $E$. coli influent concentration was removed when the hydraulic conductivity $\left(\mathrm{K}_{\mathrm{s}}\right)$ was reduced 10 or 100 times. Removal increased by $9.5 \%, 12.0 \%$ and $2.6 \%$ in sandy, sandy loam and clay loam soils, respectively, relative to removal when the model was run with $\mathrm{K}_{\mathrm{s}}$ initial values or those generated by Rosetta lite (Schaap et al., 2001) and assigned to all three soils (Figure 2. 4). These results show that the presence of a biomat layer improved the performance of the STA in terms of E. coli removal. However, the increase in bacteria removal due to the 
biomat layer is relatively modest, and its benefits must be weighed against the potential consequences of excess clogging and hydraulic failure.

Siegrist (1987) suggests that the biomat layer helps to reduce bacteria concentration by increasing the biogeochemical activity, straining, and promoting unsaturated conditions below the infiltration surface. Gerba (1975) showed that the highest bacteria removal rates occur between $2 \mathrm{~cm}$ and $6 \mathrm{~cm}$ below the infiltrative surface of the STA. These results are consistent with our data, which showed that E. coli influent concentration was reduced by $>99 \%$ between $23.3 \mathrm{~cm}$ and $28 \mathrm{~cm}$ beneath the pipe and 5 $\mathrm{cm}$ away from the trench wall when the simulated biomat layer's hydraulic conductivity was reduced by 1 or 10 orders of magnitude relative to the initial $\mathrm{K}_{\mathrm{s}}$. All three soils had greater removal rates at higher hydraulic conductivity values at observation profile points located $5 \mathrm{~cm}$ lateral distance from the trench sidewall (Figure 2. 4b). This is because, at a higher biomat hydraulic conductivity, STE no longer ponds on the biomat layer or the trench wall (Finch et al., 2008). As illustrated in

a - c, flow around the biomat layer results in more treatment because the water flow is forced to pass over the sidewall trench and bacteria are transported through a longer path, which also results in more interaction with the soil matrix. However, when most of the STE infiltrates through the biomat, and the conductivity of the biomat is higher (Figure $2.5 \mathrm{~d}$ ), any water flowing sideways from the trench must pass through the biomat wall layer, resulting in a higher bacteria concentration. 


\section{Precipitation events}

The precipitation scenarios that were modeled to evaluate the influence of infiltrated precipitation on E. coli removal in the three soils are summarized in Table 2. 3 . For the sand and sandy loam soils, no surface runoff was observed during the simulation of any precipitation events, indicating that applied rainwater was infiltrated completely. However, results could not be obtained for the clay loam soil, because when the precipitation rate exceeded the soil hydraulic conductivity, HYDRUS could not produce a numerical solution. For the sand and sandy loam soils, the results showed that E. coli travels deeper in the soil profile with increasing rainfall (Figure 2.6). For instance, at a depth of $42 \mathrm{~cm}, E$. coli was still detected when a total of $35 \mathrm{~cm}$ rain occurred during the preceding 12 days and the HLR was increased 1.7 times. Under these conditions, bacteria removal was $98.7 \%$, whereas $99.99 \%$ removal was observed when the precipitation was lower. Changes in removal were minor beneath the pipe when 5- to $35-\mathrm{cm}$ rain events infiltrated from the soil surface over a 12-day period. Similar results were observed in laboratory mesocosm experiments, with addition of excess water causing the bacteria concentration in the effluent to spike (data not shown). Independent of the precipitation scenario, at $70-\mathrm{cm}$ depth bacteria were almost completely removed $(99.00 \%$ to $99.99 \%)$ at all observation nodes.

Decreased bacteria removal rates in response to increasing amounts of rainfall may be due to the development of near-saturated or saturated flow conditions, which occur temporarily during rain events (Table 3 ). This is because bacteria survival is greater in moist soil than in dry soil (Campbell and Beiderbeck, 1976; Kibbey et al., 1978). In the model, this phenomenon is caused by soil water content variations and, as a result, the 
die-off rates are affected (i.e. water-content dependence of die-off and attachment rates, Eq. 3 and 4). Furthermore, soils exposed to prolonged dry periods - and consequently lower moisture contents - have a negative effect on the survival of E. coli, increasing their die-off rates (Berry and Miller, 2005; Habteselassie et al., 2008; Ishii et al., 2010). In addition, Cheng and Saiers (2009) suggested that bacteria can be mobilized during drainage events because of pore-scale changes in the air-water configuration, leading to an increase in bacteria concentrations in drainage water. Changes in water content may produce a moving air-water interface, resulting in mobilization of colloids, including pathogens, attached to the air-water interface, and/or scour loosely associated colloids from the solid-water interface (Crist et al., 2004; Bradford et al., 2013).

\section{Soil Temperature}

The effects of temperature on bacteria removal at soil temperatures in moderate to warmer climates of the United States $\left(5^{\circ} \mathrm{C}\right.$ to $\left.20^{\circ} \mathrm{C}\right)$ and under climate changing conditions (assuming a $3{ }^{\circ} \mathrm{C}$ increase relative to standard condition temperature, or $23^{\circ} \mathrm{C}$ (IPCC, 2013)) are shown in Figure $2.7 \mathrm{a}$ and $\mathrm{b}$. The model was run with all temperature values kept constant for every simulated scenario. The effects of temperature on bacteria removal at a given depth, ranging from $10 \mathrm{~cm}$ to $105 \mathrm{~cm}$, are summarized in Figure 2.8. Bacterial reduction increased with increasing temperature in all soils, beneath the STEfeeding pipe and near the trench wall, at all depths. In the temperature range of most soils in moderate to warm climates $\left(5{ }^{\circ} \mathrm{C}\right.$ to $\left.20{ }^{\circ} \mathrm{C}\right)$, higher temperatures resulted in increased bacteria removal. For example, in sand at a depth of $10 \mathrm{~cm}$, less than $20 \%$ of $E$. coli were removed at $5^{\circ} \mathrm{C}$, whereas about 3.5 times more $(71.9 \%)$ was removed when the soil temperature was $20^{\circ} \mathrm{C}$. Conversely, low temperatures increased the soil depth necessary 
to achieve complete bacteria removal (Figure 2.8). This effect was most pronounced in the coarsest soil (sand), which required a depth of at least $105 \mathrm{~cm}$ for complete removal, relative to only $70 \mathrm{~cm}$ when the temperature was equal to or higher than the "standard" condition of $20^{\circ} \mathrm{C}$. Differences in bacteria removal between the standard and climate change temperature scenarios are attributable to the temperature-dependent die-off and attachment/detachment coefficients calculated by the model (i.e. water content dependence of die-off and attachment rates, Eq. 3 and 4). Our results indicate that lower temperatures promote the survival of E. coli, which is consistent with Sjogren (1994), who observed greater survival of $E$. coli in soil sat $5{ }^{\circ} \mathrm{C}$ than at higher temperatures. Franz et al. (2014) carried out a meta-regression analysis, which evaluated a series of studies about commensal and pathogenic E. coli survival in soil and water (54 studies for soil and 55 studies for water). E. coli type, location, soil texture and moisture, water type (fresh water, wastewater, groundwater, drinking water), temperature and $\mathrm{pH}$ were among the factors thought to affect $E$. coli die-off rates in soil and water. The results showed that all the factors mentioned previously have an effect on death rate variation, and temperature is one of the most important environmental stressors. They also found that most of the reviewed articles exhibit a positive correlation between decline rate and temperature in water and soil; that is, the decline rate increased with increasing temperature. A similar trend was reported in a number of studies focused on bacteria dieoff rates under saturated conditions (Foppen and Schivjen, 2006). An increase in die-off rate per degree $\left({ }^{\circ} \mathrm{C}\right)$ was evident in most experiments. As a result, the average die-off rate were 3.5 times higher at $20^{\circ} \mathrm{C}\left(3.5 \times 10^{-4} \mathrm{~min}^{-1}\right)$ compared to that observed at $10{ }^{\circ} \mathrm{C}(1.0 \mathrm{x}$ $10^{-4} \mathrm{~min}^{-1}$ ). Similarly, Gerba (1975) found that low temperatures support the survival of 
enteric pathogenic bacteria for months or even years. Some researchers (Shaw, 1970; Fletcher, 1977) attribute the decrease in bacteria attachment with decreasing temperature to (i) higher viscosity of bacterial surface polymers, (ii) reduced chemisorption and physical adsorption, and (iii) changes in the physiology of the organisms. None of these factors can be simulated in HYDRUS, therefore we are unable to gauge their potential impact on the fate and transport of bacteria in the STA OWTS.

At elevated environmental temperatures, some researchers have reported that bacteria inactivation increases (Kristiansen, 1981; StenstrØm et al., 1982; Shah et al., 1994). Our results indicate that in a climate change scenario $\left(23^{\circ} \mathrm{C}\right)$, E. coli reduction was slightly increased in the sand, sandy loam and clay loam at 10-cm depth below influent pipe and trench sidewall (Figure 2.7a and b). However, the concentration of $E$. coli was reduced at a shallower depth relative to $20^{\circ} \mathrm{C}$. At $23{ }^{\circ} \mathrm{C}$, bacteria were removed at $23.3-\mathrm{cm}$ depth in all soils, except for sandy loam, where E. coli traveled deeper and was almost completely removed $(99.99 \%)$ at $27-\mathrm{cm}$ depth. At a higher temperature (23 ${ }^{\circ} \mathrm{C}$ ), the bacteria attachment rate is higher (Hendricks et al., 1979), which enhances bacteria removal by interaction with soil particles. Our modeling results suggest that the soil temperature has an important effect on bacteria die-off rate coefficients. This finding has implications for how the STA might respond to a warming climate. 


\section{MODEL IMPLICATIONS ON BACTERIA REMOVAL RATES}

The removal of bacteria is influenced by the variable environmental and operational conditions assumed for each of the simulated scenarios for the conventional OWTS. The changes in removal rates are most evident, specifically, for the first $23 \mathrm{~cm}$ below the distribution pipe. Higher removal rates were computed by the model (at shallower depths) when the hydraulic loading rate was lowered $50 \%$ and the wastewater infiltrated in a clay loam soil. These results explain the importance of soil texture and flow rates for system design. A simulated biomat also improved the bacteria removal percentages due to a lower hydraulic conductivity or clogged soil pores on the surface (modeled biomat growth). This is consistent with studies that showed a higher removal efficiency of bacteria in clogged soil treatment areas or sand filters compared to unclogged systems (Kristiansen, 1981). The modeled precipitation event scenarios did not cause significant changes in the model outputs or removal rates, and no variation was observed in the OWTS performance. A higher rainfall intensity needs to be applied over the soil surface to ensure that more bacteria are detected on the effluent concentration because of water saturation.

All of the modeled scenarios and conditions may be considered as OWTS performance evaluation. Our results can help to define system design (i.e., size and type of system) by incorporating data on wastewater, soil physical/chemical properties and site properties. Inappropriately designed or failed OWTS are sources of surface and groundwater contamination, which present a serious public health risk (US EPA, 2002). Bacteria are of great concern because they can be transported for long distances in water bodies, causing illness through body contact or ingestion of contaminated water. 


\section{CONCLUSIONS}

Although perhaps considered a shortcoming, we do not consider the lack of model validation critical for our study because, based on the three experimental data sets considered herein, the observed trends can likely be extrapolated to other STAs. However, our results would no doubt be strengthened if the model could be used to predict the outcome of future studies. At the same time, our model's precision would increase, making its results more realistic, if additional system parameters were based on experimental data.

We successfully simulated the retention of $E$. coli in the STA of a conventional soil-based wastewater treatment system for three soil types using HYDRUS 2D/3D. The model was developed to gain insights into the possible effects of initial concentration of bacteria, HLR, presence of a biomat, precipitation events and temperature on the performance of the system.. In terms of operation, lowering the hydraulic loading rates was more effective in removing bacteria because, when the soil water content is lower, bacteria transport occurs under unsaturated conditions, which prolongs and enhances the interaction of the bacteria with soil particles.

Abiotic factors that are expected to change in a changing climate, such as precipitation events and soil temperature, also affect the E. coli removal in the drainfield. Our results indicate that increased precipitation can mobilize bacteria, causing them to travel deeper in the soil profile. This has implications for the performance of OWTS should it receive greater than historical amounts of precipitation, as predicted for some areas, including the northeastern United States, under climate change (IPCC, 2014). On the other hand, under anticipated increases in temperature due to climate change, bacteria 
are likely to experience higher die-off rates compared to cooler temperatures, which suggests that the effectiveness of the STA will increase as the average soil temperature rises. Our findings also identified a role for soil texture in E. coli reduction, with finer textured soils removing more bacteria than coarser textured soils. The simulation of variable stress conditions suggests that environmental and operational factors influence the performance of soil-based wastewater treatment, and that this treatment will likely respond to changing temperature and precipitation patterns predicted by climate change models. Which of these factors becomes more influential, and how these factors correlate with other environmental or operational factors not considered in this study, remains to be evaluated. 


\section{REFERENCES}

Amador, J. A. and J. A. Atoyan. 2012. Structure and composition of leachfield bacterial communities: role of soil texture, depth and septic tank effluent inputs. Water 4(3): 707- 719.

Beal, C.D., E.A. Gardner, G. Kirchhof, and N.W. Menzies. 2006. Long-term flow rates and biomat zone hydrology in soil columns receiving septic tank effluent. Water Res. 40: 2327-2338.

Berry, E. D., and D. N. Miller. 2005. Cattle feedlot soil moisture and manure content: II. Impact on Escherichia coli O157. J. Environ. Qual. 34: 656-663.

Bogosian, G., L.E. Sammons, P.J.L. Morris, J.P. O’Neill, M.A. Heitkamp, and D.B. Webber. 1996. Death of Escherichia coli K-12 strain W3110 in soil and water. Appl. Environ. Microbiol. 62: 4114- 4120.

Bouma J., F.G. Baker, and P.L.M. Veneman. 1974. Measurement of water movement in soil pedons above the water table. Information circular no. 27. Madison, WI: University of Wisconsin.

Campbell C.A., and V.O. Beiderbeck. 1976. Soil bacterial changes as affected by growing season weather conditions: a field and laboratory study. Can. J. Soil Sci. $56: 293-310$.

Canter, L.W., and R.C. Knox. 1985. Septic Tank System Effects on Ground Water Quality; Lewis Publishers, Inc.: Chelsea, MI, USA.

Cheng, T., and J. E. Saiers. 2009. Mobilization and transport of in situ colloids during drainage and imbibitions of partially saturated sediments. Water Resour. Res. 45 W08414.

Chu, Y., Y. Jin, T. Baumann, and M. Yates. 2003. Effect of soil properties on saturated and unsaturated virus transport through columns. J. Environ. Qual. 32: 20172025 . 
Crites, R.W. 1985. Micropollutant Removal in Rapid Infiltration. In Artificial Recharge of Groundwater; $\quad$ Butterworth Publishers: Waltham, MA, USA.

Crist, J. T., J. McCarthy, F. Y. Zevi, P. Baveye, J. A. Throop, and T.S. Steenhuis. 2004. Pore-scale visualization of colloid transport and retention in partly saturated porous media. Vadose Zone J. 3: 444-450.

Dowd, S. and S. Pillai. 1997. Survival and Transport of selected bacterial pathogens and indicator viruses under sandy aquifer conditions . J. Environ. Sci. Health 32 (8): 2245-58.

Ellwood, D.C., C.W. Keevil, P.D. Marsh, C.M. Brown, and J.N. Wardell. 1982. Surfaceassociated growth. Phil. Trans R. Soc. (London) 297: 517-32.

Finch, S. D., D. E. Radcliffe, and L. T. West. 2008. Modeling trench sidewall and bottom flow in on-site wastewater systems. J. Hydrol. Eng.. 13 (8): 693 - 701.

Foppen, J.W., and J.F. Schijven. 2006. Evaluation of data from the literature on the transport and survival of Escherichia coli and thermotolerant coliforms in aquifers under saturated conditions. Water Res. 40(3): 401-26.

Fletcher, M. 1977. Effects of culture concentration and age, time, and temperature on bacterial attachment topolystyrene. Can. J. Microbiol. 23:1-6.

Franz, E., J. Schijven, A. de Roda Husman and H. Blaak. 2014. Meta - regression analysis of commensal and pathogenic Escherichia coli survival in soil and water. Environ. Sci. Technol. 48 (12), pp 6763-6771.

Gargiulo, G., S.A. Bradford, J. Simunek, P. Ustohal, H. Vereecken, and E. Klumpp. 2008. Bacteria transport and deposition under unsaturated flow conditions: the role of water content and bacteria surface hydrophobicity. Vadose Zone J. 7: 406419.

Gelhar, L. W., C. Welty, and K. R. Rehfeldt. 1992. A critical review of data on fieldscale dispersion in aquifers, Water Resour. Res., 28(7), 1955-1974. 
Gerba C.P., 1975. Fate of wastewater bacteria and viruses in soil. J. Irr. Dr. Div. 101: 157-173.

Gerba, C.P. and S.M. Goyal. 1985. Pathogen Removal from Wastewater During Groundwater Recharge. In Artificial Recharge of Groundwater; Butterworth Publishers: Waltham, MA, USA.

Habteselassie, M., M. Bischoff, E. Blume, B. Applegate, B. Reuhs, S. Brouder, and R. F. Turco. 2008. Environmental controls on the fate of Escherichia coli in soil. Water Air Soil Pollut. 190: 143-155.

Hendricks, D.W., F.J. Post, and D.R. Khairnar. 1979. Adsorption of bacteria on soils. Water Air Soil Pollut. 12: 219-32.

IPCC, 2013. Climate Change 2013: The Physical Science Basis. Contributions of Working Group I to the Fifth Assessment Report of the Intergovernmental Panel on Climate Change, Stocker, T.F., D. Qin, G.-K. Platter, M. Tignor, S.K. Allen, J. Boschung, A. Nauels, Y. Xia, V. Bex and P.M. Midgley (eds.). Cambridge University Press, Cambridge, United Kingdom and New York, NY, USA, 1535p.

IPCC 2014. Climate Change 2014: Impacts, Adaptation, and Vulnerability. Part B:

Regional Aspects. Contribution of Working Group II to the Fifth Assessment Report of the Intergovernmental Panel on Climate Change [Barros, V.R., C.B. Field, D.J. Dokken, M.D. Mastrandrea, K.J. Mach, T.E. Bilir, M. Chatterjee, K.L. Ebi, Y.O. Estrada, R.C. Genova, B. Girma, E.S. Kissel, A.N. Levy, S. MacCracken, P.R. Mastrandrea, and L.L. White (eds.)]. Cambridge University Press, Cambridge, United Kingdom and New York, NY, USA, 688 pp.

Ishii, S., T. Yan, H.Vu, D. L. Hansen, R. E. Hicks, and M. J. Sadowsky. 2010. Factors controlling long-term survival and growth of naturalized Escherichia coli populations in temperate field soils. Microbes Environ 25(1): 8-14.

Jarret, A.R. 2014. Pennsylvania State University, Cooperative Extension, College of Agricultural Sciences. Biomats (No. F-159) [Fact Sheet]. Retrieved from 
http://extension.psu.edu/natural-resources/water/septic-systems/on-sitewastewater-treatment- system-options/biomats.

Jiang, S., P. Liping, G. D. Buchan, J. Simůnek, M. J. Noonan, and M.E. Close. 2010. Modeling water flow and bacterial transport in undisturbed lysimeters under irrigations of dairy shed effluent and water using HYDRUS-1D. Water Res. 44: $1050-1061$.

Karathanasis, A.D., T.G. Mueller, B. Boone, and Y.L. Thompson. 2006. Effect of soil depth and texture on fecal bacteria removal from septic effluents. Water Health. 4: 395-404.

Keswick, B.H., and C.P. Gerba. 1980. Viruses in groundwater. Environ. Sci.Technol. 14: 1290-1297.

Keys, J. R., E. J. Tyler, and J. C. Converse.1998. Predicting Life for Wastewater Absorption Systems. Proc. Eighth National Symposium on Individual and Small Community Sewage Systems, ASAE, St. Joseph, MI. P. 167-176.

Kibbey H.J., C. Hagedorn and E.L. McCoy. 1978. Use of fecal streptococci as indicators of pollution in soil. Appl. Environ. Microbiol. 35:711-719.

Kirtman, B., S.B. Power, J.A. Adedoyin, G.J. Boer, R. Bojariu, I. Camilloni, F.J. DoblasReyes, A.M. Fiore, M. Kimoto,G.A. Meehl, M. Prather, A. Sarr, C. Schär, R. Sutton, G.J. van Oldenborgh, G. Vecchi, and H.J. Wang. 2013. Near-term climate change: Projections and Predictability. In: Climate Change 2013: The Physical Science Basis. Contributionof Working Group I to the Fifth Assessment Report of the Intergovernmental Panel on Climate Change [Stocker,T.F., D. Qin, G.-K. Plattner, M. Tignor, S.K. Allen, J. Boschung, A. Nauels, Y. Xia, V. Bex and P.M. Midgley (eds.)].Cambridge University Press, Cambridge, United Kingdom and New York, NY, USA.

Kristiansen, R. 1981. Sand-filter trenches for purification ofseptic tank effluent: III: The microflora. J. Environ. Qual. 10: 361-4. 
Lance, J.C. and C.P. Gerba. 1984. Virus movement in soil during saturated and unsaturated flow. Appl. Environ. Microbiol. 47: 335-7.

McDowell-Boyer L.M., J.R. Hunt, and N. Sitar. 1986. Particle transport in porous media. Water Resour. Res. 22: 1901-1921.

McCray, J., K.S. Lowe, M. Geza, J. Drewes, S. Roberts, A. Wunsch, D. Radcliffe, J. Amador, J. Atoyan, T. Boving, D. Kalen, and G. Loomis. 2009. State of the Science: Review of Quantitative Tools to Determine Wastewater Soil Treatment Unit Performance. Water Environment Research Foundation. Technical Report DEC1R06,.

Moore, S.K., R.T. Garvin, and E. James, .1981. Nucleotide sequence of the $\operatorname{argF}$ regulatory region of Escherichia Coli K-12. Gene 116, 119-132.

Morales, I., J. A. Atoyan, J. A. Amador, T. Boving, 2014.Transport of pathogen surrogates in soil treatment units: numerical modeling. Water 6: 818-838.

Ostrolenk, M., N. Kramer, and R. C. Clevedon, 1947. Comparative studies of Enterococci and E. coli as indices of pollution. J. Bacteriol. 53:197-203.

Pang, L., M. Close, M. Goltz, H. Sinton, L. Davies, C. Hall, and G. Stanton, 2004. Estimation of septic tank setback distances based on transport of Escherichia coli and F-RNA phages. Environ. Int. 29: 907-921.

Pang, L. and J. Šimůnek. 2006. Evaluation of bacteria-facilitated cadmium transport in gravel columns using the HYDRUS colloid-facilitated solute transport model. Water Resour. Res. 42: 1-13 W12S10.

Pang, L., M.McLeod, J. Aislabie, J. Šimůnek, M. Close, and R. Hector, 2008. Modeling transport of microbes in ten undisturbed soils under effluent irrigation. Vadose Zone J. 7: 97-111.

Powelson, D. K., and J. R. Simpson, 1990. Virus transport and survival in saturated and unsaturated flow through soil columns. J. Environ. Qual., 19 (3): 396-401. 
Radcliffe, D. E. and L. T. West. 2009. Design hydraulic loading rates for onsite wastewater systems. Vadoze Zone J., 8: 64-74.

Reddy, K. R., R. Khaleel, and M. R. Overcash, 1981. Behavior and transport of microbial pathogens and indicator organisms in soils treated with organic wastes. J. Environ. Qual., 10:255-266.

Schaap, M.G., F.J. Leij, and M.T. van Genutchten. 2001. ROSETTA: a computer program for estimating soil hydraulic parameters with hierarchical pedotransfer functions. J. Hydrol. 251 (3-4): 163-176.

Shadford, C.B., D.M. Joy, H. Lee, H.R. Whiteley, and S. Zelin. 1997. Evaluation and use of a biotracer to study ground water contamination by leaching bed systems. J. Contam. Hydrol. 28: 227-282.

Shah R, and M.K. Bhatnagar. 1994. Survival of Xanthomonas campestris pv. vignicola causing bacterial blight of cowpea. Indian J. Mycol. Plant Pathol. 24: 206-8.

Sharma, M.M., H. Chamoun, D.S.H. Sita Rama Sarma, and R.S. Schechter. 1992. Factors controlling the hydrodynamic detachment of particles from surfaces. J. Coll. Inter. Sci. 149: 121-34.

Shaw, D.J. 1970. Introduction to colloid and surface chemistry, 2nd ed. London:Butterworths.

Siegrist R.L. 1987. Soil clogging during subsurface wastewater infiltration as affected by effluent composition and loading rate. J. Environ. Qual. 16: 181-187.

Siegrist, R.L. 2001. Advancing the science and engineering of onsite wastewater systems. In On-Site Wastewater Treatment: Proc. of the Ninth National Symposium on Individual and Small Community Sewage Systems. St. Joseph, MI: American Society of Agricultural Engineers.

Siegrist, R.L., J.E. McCray, and K.S. Lowe. 2006. Wastewater infiltration into soil and the efects of infiltrative surface architecture. Small Flows Quarterly 5 (1): 29-39. 
Šimůnek, J., M.T. van Genuchten, and M. Sejna, 2006. The HYDRUS Software Package for Simulating the Two-and Three-Dimensional Movement of Water, Heat, and Multiple Solutes in Variably-Saturated Media; Technical Manual, PC Progress: Prague, Czech Republic.

Sjogren RE. 1994. Prolonged survival of an environmental Escherichia coli in laboratory soil microcosms. Water Air Soil Pollut. 75: 389-403.

Sobsey, M.D., C.H. Dean, M.E. Knuckles, and R.A. Wagner. 1980. Interactions and survival of enteric viruses in soil materials. Appl. Environ. Microbiol. 40: 92-101.

Sobsey, M.D. and P.A. Shields. 1987. Survival and Transport of Viruses in Soils. In Human Viruses in Sediments, Sludges, and Soils; CRC Press: Boca Raton, FL, USA, pp. 155-177.

StenstrØm, T.A., and S. Hoffner. 1982. Reduction of enteric microorganisms in soil infiltration systems. In: Eikum A.S. Seabloom R.W., editors. Alternative wastewater treatment. Holland: D. Reidel Publishing and Company; p. 169-81.

Stevik, T.K., K. Aa, G. Ausland, and J.F. Hanssen. 2004. Retention and removal of pathogenic bacteria in wastewater percolating through porous media: a review. Water Res. 38(6): 1355-1367.

Tamasi, G. 1981. Factors influencing the survival of pathogenic bacteria in soils. Acta Vet. Acad. Sci. Hung. 29: 119-26.

Thomas, G.W., and R.E. Philips. 1979. Consequences of water movement in macropores. J. Environ. Qual. 8:149-52

U.S. EPA. 1997. Response to Congress on use of decentralized wastewater treatment systems. Washington, D.C.: Office of Water.

U.S. EPA. 2000. Drinking water standards and health advisories. EPA 822-B-00-001. Washington, D.C.: Office of Water. 
U.S. EPA. 2002. Onsite Wastewater Treatment Systems Manual; U.S. Environmental Protection Agency: Washington, DC, pp. 1-367.

U.S. EPA. 2014. National Summary of Impaired Waters and TMDL Information. Available online: http://iaspub.epa.gov/waters 10/attains_nation_cy.control?p_report type=T (accessed on 31 May 2014).

Van Cuyk, S.M., and R.L. Siegrist, 2007. Virus removal within a soil infiltration zone as affected by effluent composition, application rate and soil type. Water Res.. 41: 699-709.

Van Cuyk S., R.L. Siegrist, A. Logan, S. Masson, E. Fischer, and L. Figueroa. 2001. Hydraulic and purification behaviors and their interactions during wastewater treatment in soil infiltration systems. Water Res.. 35(4): 953-964.

Vanderborgt, J. and H. Vereecken. 2007. Review of dispersivities for transport modeling in soils. Vadose Zone J. 6: 29-22.

Wang, G., and M.P. Doyle, 1998. Survival of enterohemorrhagic Escherichia coli O157:H7 in water. J. Food Protec. 61: 662-667.

Yates, M., and S.R. Yates. 1988. Modeling microbial fate in the subsurface environment. Crit. Rev. Environ. Control 17: 307-44.

Zhang, H., N.A. Nordin, and M.S. Olson. 2013. Evaluating the effects of variable water chemistry on bacterial transport during infiltration. J. Contam. Hydrol. 150: 5464. 


\section{TABLES}

Table 2. 1 Soil hydraulic model parameters as generated by Rosetta lite program (Schaap et al., 2001). Those values are based on the U.S. Department of Agriculture (USDA) textural class triangle.

\begin{tabular}{|l|l|l|l|l|l|}
\hline $\begin{array}{l}\text { Textural } \\
\text { Class }\end{array}$ & $\boldsymbol{\theta}_{\boldsymbol{r}}$ & $\boldsymbol{\theta}_{\boldsymbol{s}}$ & $\boldsymbol{\alpha}$ & $\boldsymbol{n}$ & $\boldsymbol{K}_{\boldsymbol{s}}$ \\
\hline & $\mathbf{( \mathbf { c m } ^ { \mathbf { 3 } } \mathbf { c m } ^ { - \mathbf { 3 } } \mathbf { ) }}$ & $\mathbf{( \mathbf { c m } ^ { \mathbf { 3 } } \mathbf { c m } ^ { - \mathbf { 3 } } \mathbf { ) }}$ & $\mathbf{( \mathbf { c m } ^ { - \mathbf { 1 } } )}$ & {$[-]$} & $\mathbf{( \mathbf { c m ~ h r } ^ { - 1 } )}$ \\
\hline Gravel & 0.027 & 0.201 & 0.300 & 6.000 & 83.330 \\
\hline Sand & 0.045 & 0.430 & 0.145 & 2.680 & 29.700 \\
\hline Sandy loam & 0.065 & 0.410 & 0.075 & 1.890 & 4.423 \\
\hline Clay loam & 0.095 & 0.410 & 0.019 & 1.310 & 0.260 \\
\hline
\end{tabular}

\footnotetext{
$\theta_{r}$, residual water content

$\theta_{s}$, saturated water content

$\alpha$, fitting parameter inversely related to air-entry pressure value

$n$, fitting parameter related to pore-size distribution

$K_{s}$, saturated hydraulic conductivity
} 
Table 2. 2 Relative and absolute hydraulic conductivity values of the biomat at the trench bottom and sidewalls (Material 3). Also included is the value for the gravel layer (Material 2).

\begin{tabular}{lll}
\hline \multirow{2}{*}{$\begin{array}{l}\text { Relative } \\
\text { Hydraulic } \\
\text { Conductivity }\end{array}$} & $\begin{array}{l}\text { Absolute } \\
\text { Hydraulic Conductivity } \\
\text { Material 2 }\end{array}$ & Material 3 \\
& & \\
\hline & $\left(\mathrm{cm} \mathrm{h}^{-1}\right)$ & $\left(\mathrm{cm} \mathrm{h}^{-1}\right)$ \\
1 & 83.33 & 0.0085 \\
0.1 & 83.33 & 0.0017 \\
0.01 & 83.33 & 0.00017 \\
\hline
\end{tabular}


Table 2. 3. Summary of infiltration patterns simulated to stress the trench treatment system.

\begin{tabular}{ll}
\hline Scenario & Infiltration Rates \\
\hline $5 \mathrm{~cm}$ & $2.5 \mathrm{~cm} \mathrm{~h}^{-1}$ for two hours on day 12. \\
\hline $10 \mathrm{~cm}$ & $\begin{array}{l}1 \mathrm{~cm} \mathrm{~h}^{-1} \text { for five hours on day } 1 \text { followed by } 2.5 \mathrm{~cm} \mathrm{~h}^{-1} \text { for two } \\
\text { hours on day } 12 .\end{array}$ \\
\hline $15 \mathrm{~cm}$ & $\begin{array}{l}1 \mathrm{~cm} \mathrm{~h}^{-1} \text { for five hours on day } 1 \text { followed } 0.5 \mathrm{~cm} \mathrm{~h}^{-1} \text { for ten } \\
\text { hours on days } 4 \text { followed by } 2.5 \mathrm{~cm} \mathrm{~h}^{-1} \text { for two hours on day } \\
12 .\end{array}$ \\
\hline $25 \mathrm{~cm}$ & $\begin{array}{l}1 \mathrm{~cm} / \mathrm{hr} \text { for five hours on day } 1 \text { followed } 0.5 \mathrm{~cm} \mathrm{~h}^{-1} \text { for ten } \\
\text { hours on days } 4 \text { and } 8 \text { followed by } 2.5 \mathrm{~cm} \mathrm{~h}^{-1} \text { for two hours on } \\
\text { day } 12 .\end{array}$ \\
\hline $35 \mathrm{~cm}$ & $\begin{array}{l}1 \mathrm{~cm} \mathrm{~h}^{-1} \text { for five hours on day } 1 \text { followed } 0.5 \mathrm{~cm} \mathrm{~h}^{-1} \text { for ten } \\
\text { hours on days } 2,4,6,8, \text { and } 10 \text { followed by } 2.5 \mathrm{~cm} \mathrm{~h}^{-1} \text { for two } \\
\text { hours on day } 12 .\end{array}$ \\
\hline $35 \mathrm{~cm} /$ HLR & $\begin{array}{l}\text { As scenario “35 cm" but with HLR increased } 1.7 \text { times (from } \\
\left.0.424 \mathrm{~cm} \mathrm{~h}^{-1}\right)\end{array}$ \\
\hline
\end{tabular}




\section{FIGURES}

Figure 2. 1. (A) Conventional onsite wastewater treatment system (OWTS) model domain and porous material distribution, (B) boundary conditions and (C) observation nodes for HYDRUS simulations. All dimensions are in $\mathrm{cm}$.
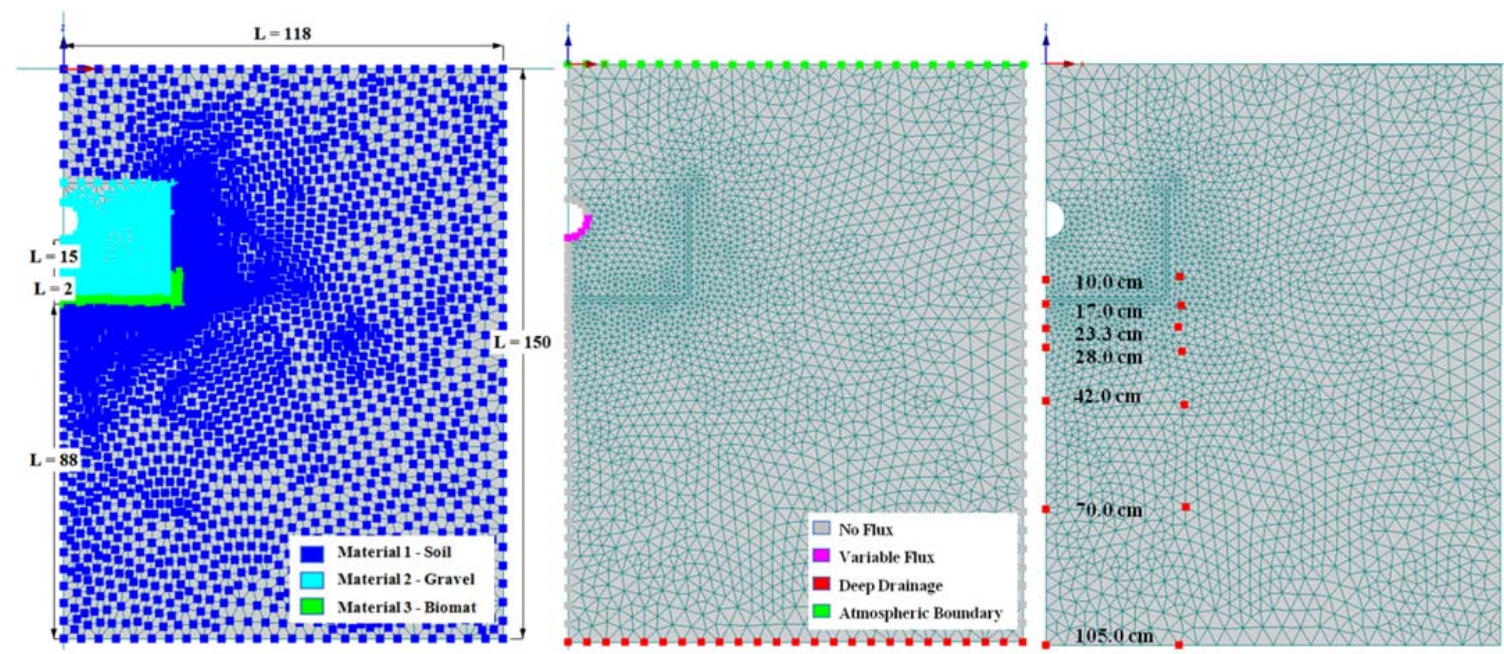
Figure 2. 2 Effect of soil texture on reduction of $E$. coli concentration at an initial influent E. coli concentration of $10^{5} \mathrm{cfu} \mathrm{mL}^{-1}$. Model concentrations are shown for five observation points located at $10 \mathrm{~cm}, 17 \mathrm{~cm}, 23.3 \mathrm{~cm}, 28 \mathrm{~cm}$ and $42 \mathrm{~cm}$ below the influent pipe (a) and trench sidewall (b).

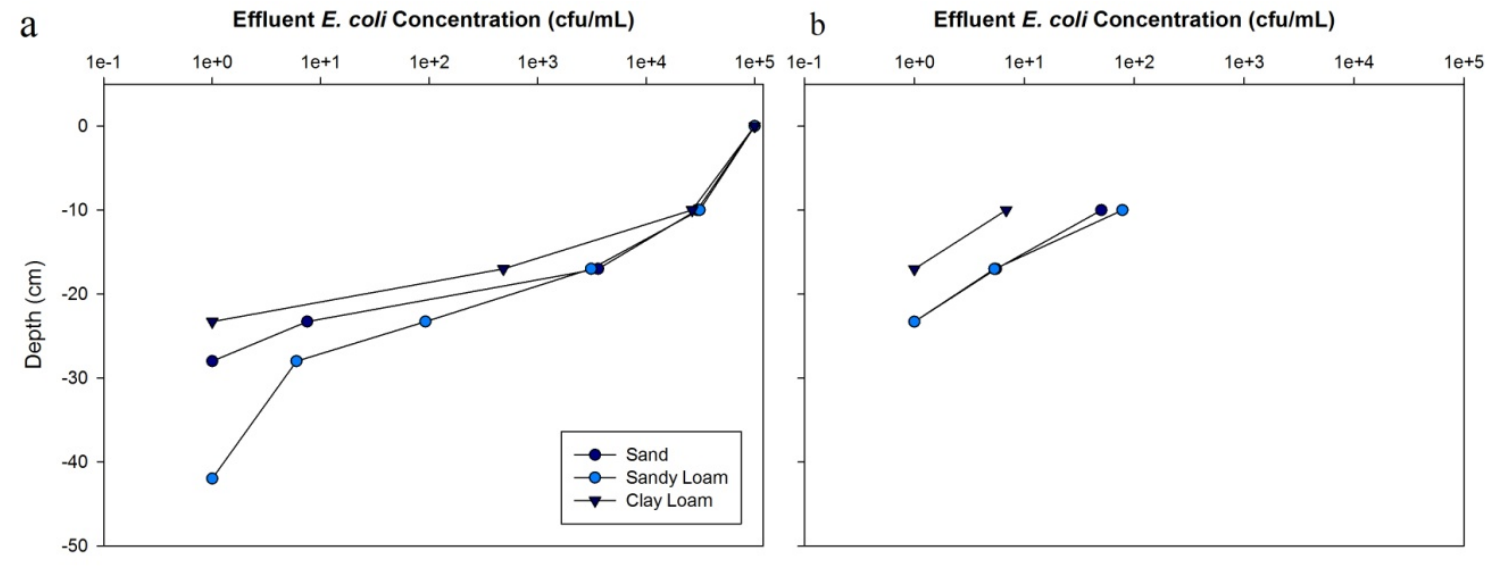


Figure 2. 3 Reduction of $E$. coli concentration in sandy, sandy loam, and clay loam soils as a function of variable hydraulic loading rate (HLR; $\mathrm{cm} \mathrm{h}^{-1}$ ) at an influent $E$. coli concentration of $10^{5} \mathrm{cfu} \mathrm{mL}^{-1}$. Model concentrations are shown for five observation points located at $10 \mathrm{~cm}, 17 \mathrm{~cm}, 23.3 \mathrm{~cm}, 28 \mathrm{~cm}$ and $42 \mathrm{~cm}$ below the influent pipe (a) and trench sidewall (b).

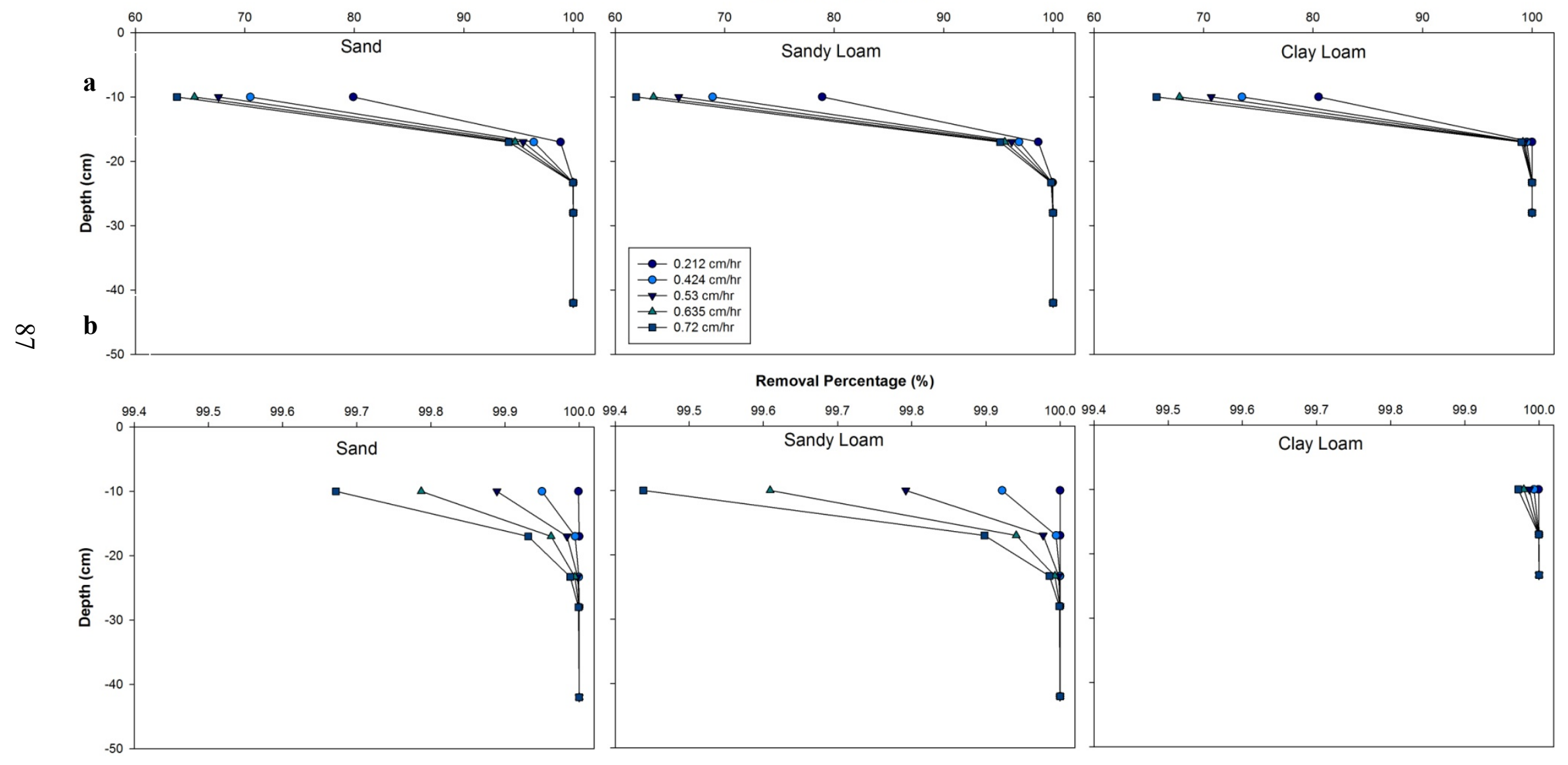


Figure 2. 4 Reduction of $E$. coli concentration in sandy, sandy loam and clay loam soils as a function of variable hydraulic conductivity of the biomat layer at an influent $E$. coli concentration of $10^{5} \mathrm{cfu} \mathrm{mL}^{-1}$. The initial hydraulic conductivity of the trench gravel was $83.3 \mathrm{~cm} \mathrm{~h}^{-1}$ and $0.0017 \mathrm{~cm} \mathrm{~h}^{-1}$ for the biomat. Model concentrations are shown for five observation points located at $10 \mathrm{~cm}$, $17 \mathrm{~cm}, 23.3 \mathrm{~cm}, 28 \mathrm{~cm}, 42 \mathrm{~cm}$ and $70 \mathrm{~cm}$ below the influent pipe (a) and trench sidewall (b). Numbers in the legend are initial hydraulic conductivity multipliers.
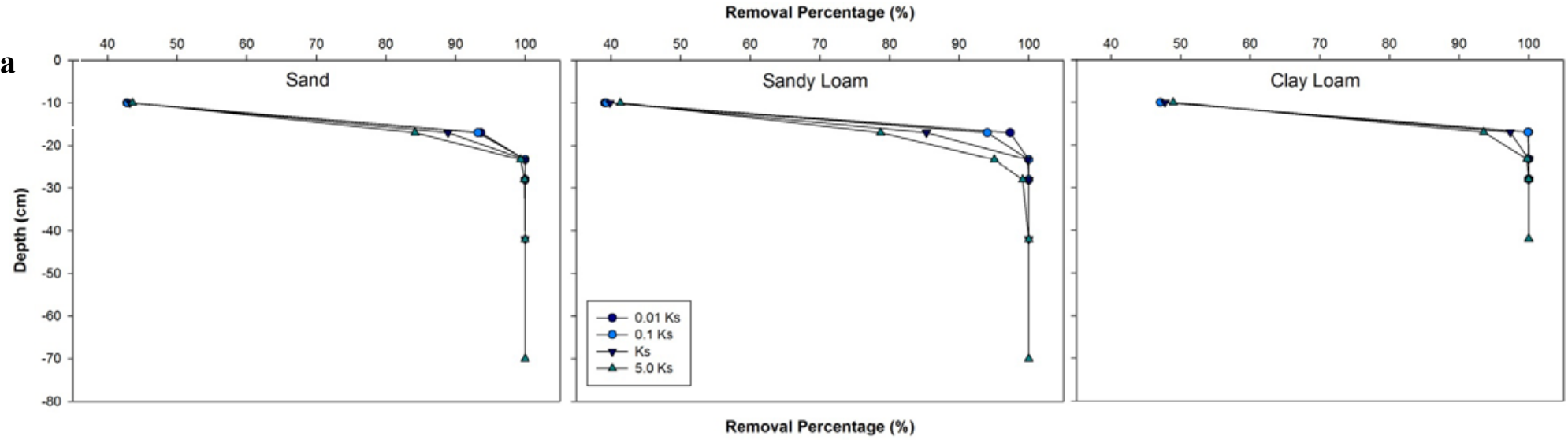

b
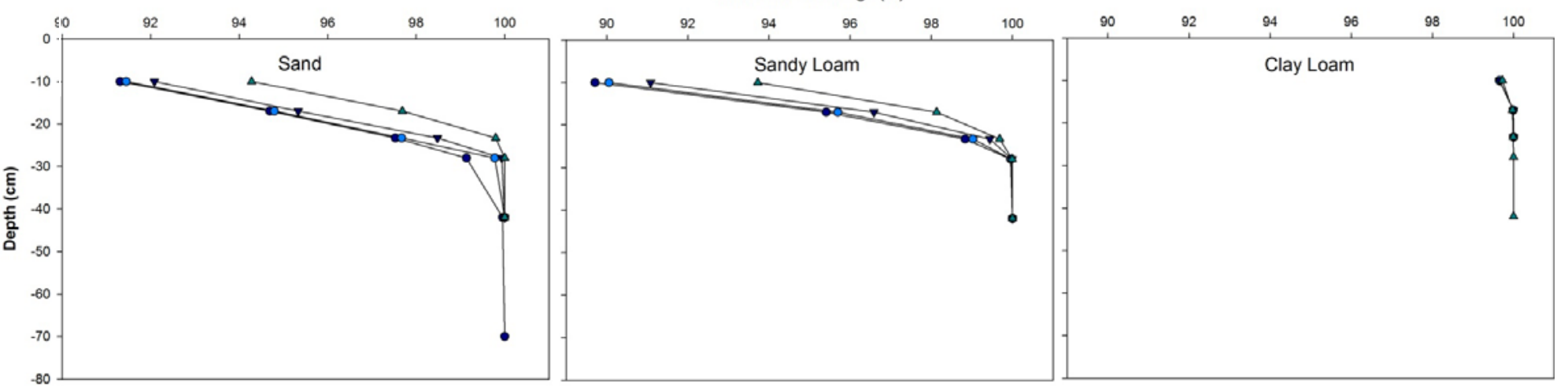
Figure 2. 5 Flow direction indicated by velocity vectors in the trench after 96 hours operation for the sandy soil with sidewall and bottom biomat hydraulic conductivity equal to: (A) $0.01 \mathrm{Ks}$, (B) $0.1 \mathrm{Ks}$, (C) Ks, and (D) $5.0 \mathrm{Ks}$. In all scenarios, the STE enters the trench through the horizontal drain pipe, flows out of the trench, and infiltrates into the bottom and sidewall. When the biomat is simulated under low conductivity values, no flow is observed through the trench bottom; instead, STE flows over the sidewall biomat on the right and E. coli concentration increases. Similar results were observed for sandy loam and clay loam soils (not shown).

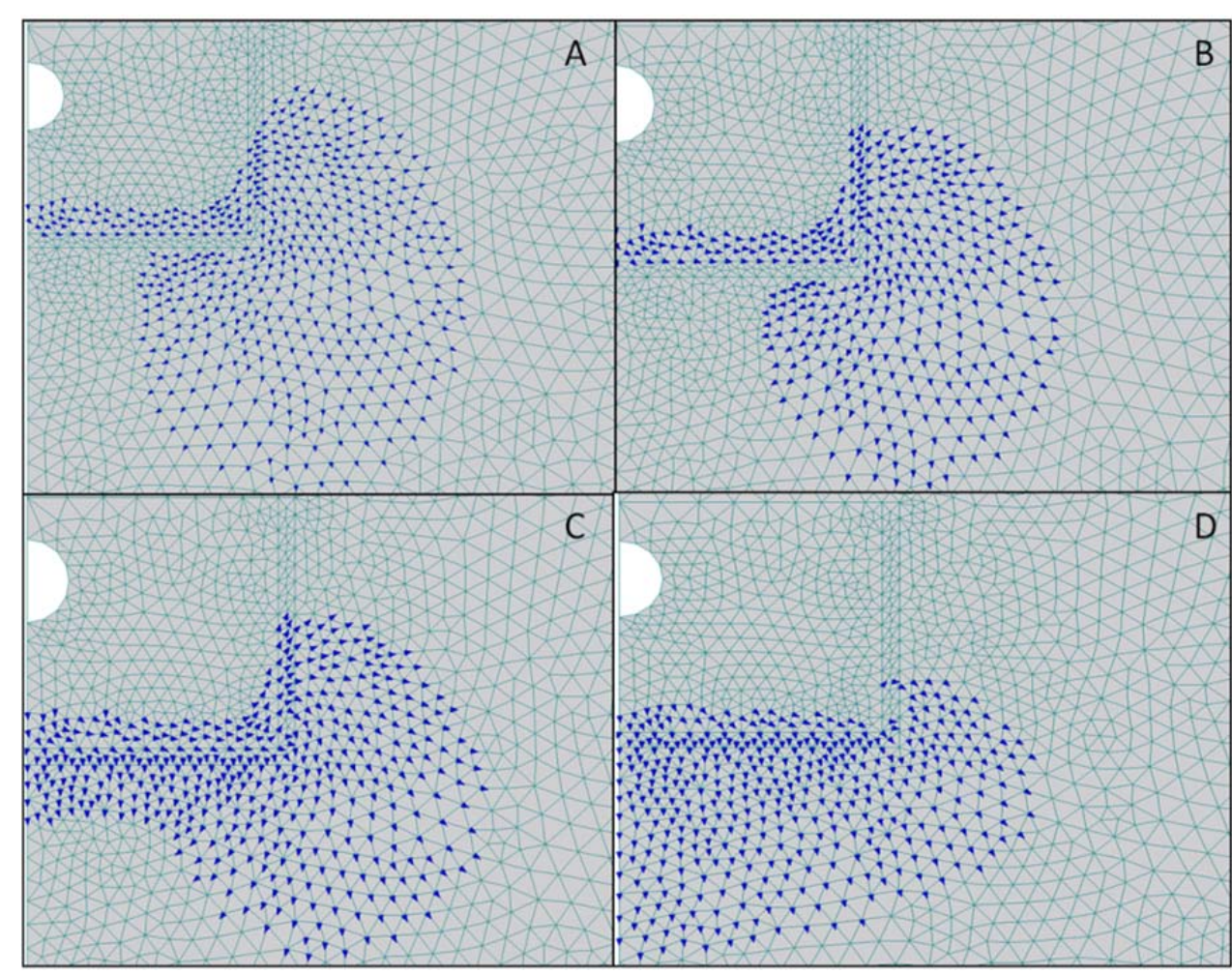


Figure 2. 6 Reduction of E. coli concentration in sandy, sandy loam, and clay loam soils as a function of variable surface infiltration events at an influent $E$. coli concentration of $10^{5} \mathrm{cfu} \mathrm{mL}^{-1}$. Model concentrations are shown for five observation points located at 10 $\mathrm{cm}, 17 \mathrm{~cm}, 23.3 \mathrm{~cm}, 28 \mathrm{~cm}, 42 \mathrm{~cm}$ and $70 \mathrm{~cm}$ below the influent pipe (a) and trench sidewall (b). No results are shown for clay soil (see text for details).
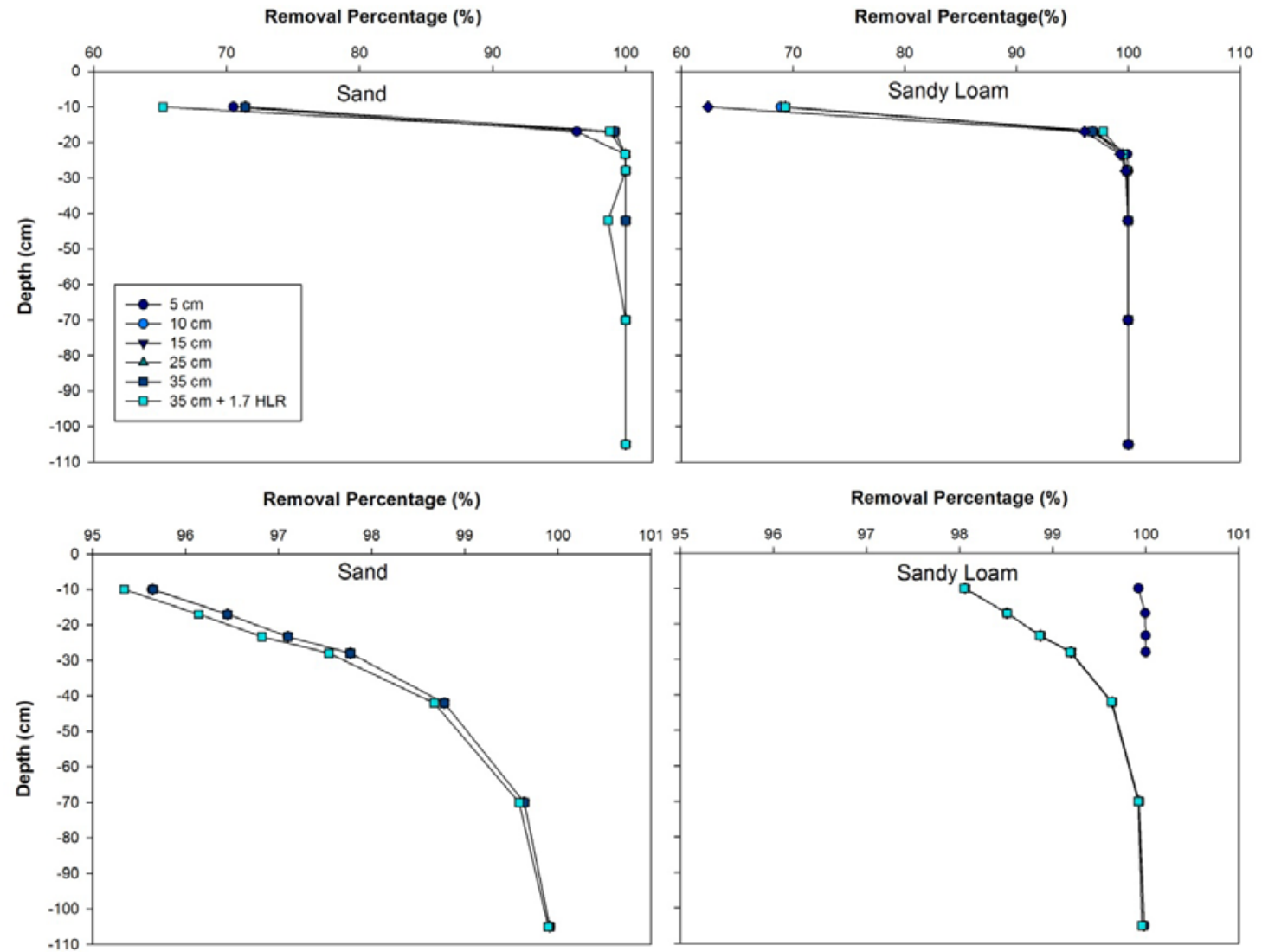
Figure 2. 7 Reduction of $E$. coli concentration in sandy, sandy loam, and clay loam soils as a function of variable soil temperature, under moderate to warmer $\left(5^{\circ} \mathrm{C}\right.$ to $\left.20{ }^{\circ} \mathrm{C}\right)$ and under climate changing conditions $\left(23{ }^{\circ} \mathrm{C}\right)$, at an influent $E$. coli concentration of $10^{5}$ cfu $\mathrm{mL}^{-1}$. Model concentrations are shown for five observation points located at $10 \mathrm{~cm}, 17 \mathrm{~cm}, 23.3 \mathrm{~cm}, 28 \mathrm{~cm}$ and $42 \mathrm{~cm}$ below the influent pipe (a) and trench sidewall (b).
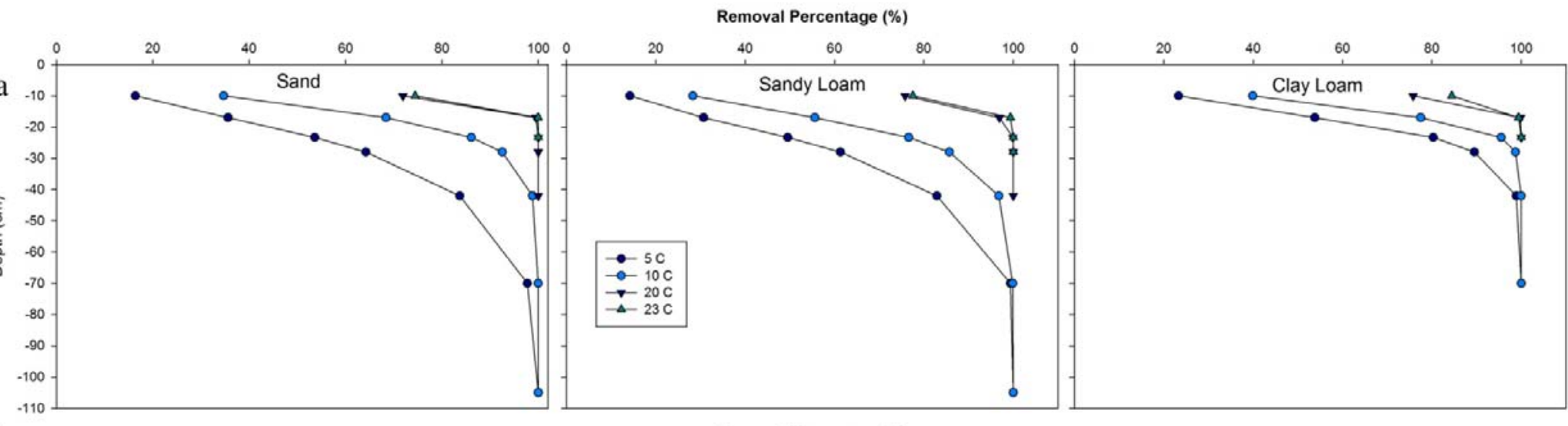

b

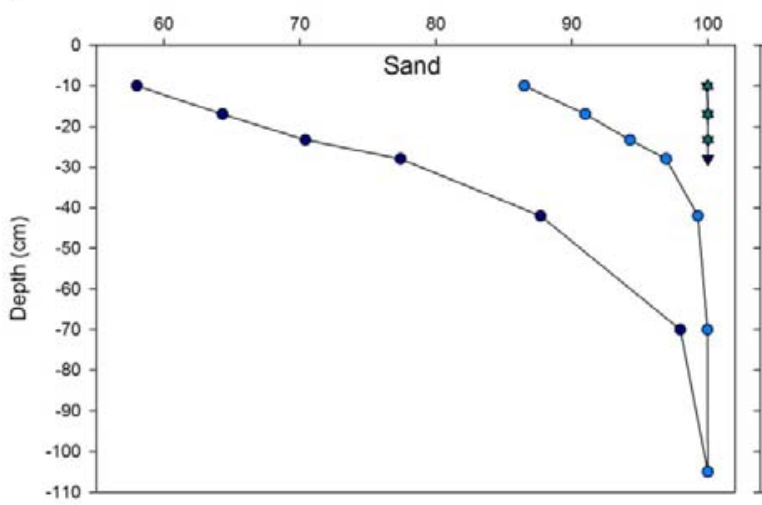

Removal Percentage (\%)

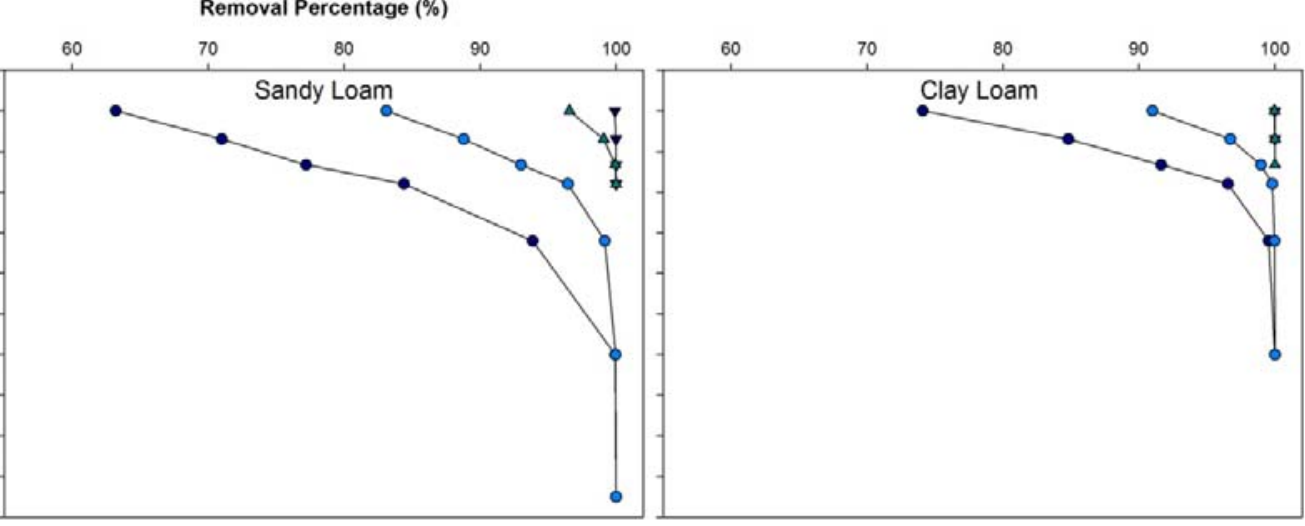


Figure 2. 8 Effect of temperature on E. coli removal for sandy, sandy loam, and clay loam soils at $10 \mathrm{~cm}, 17 \mathrm{~cm}, 23.3 \mathrm{~cm}, 28 \mathrm{~cm}, 42$ $\mathrm{cm}, 70 \mathrm{~cm}$ and $105 \mathrm{~cm}$.

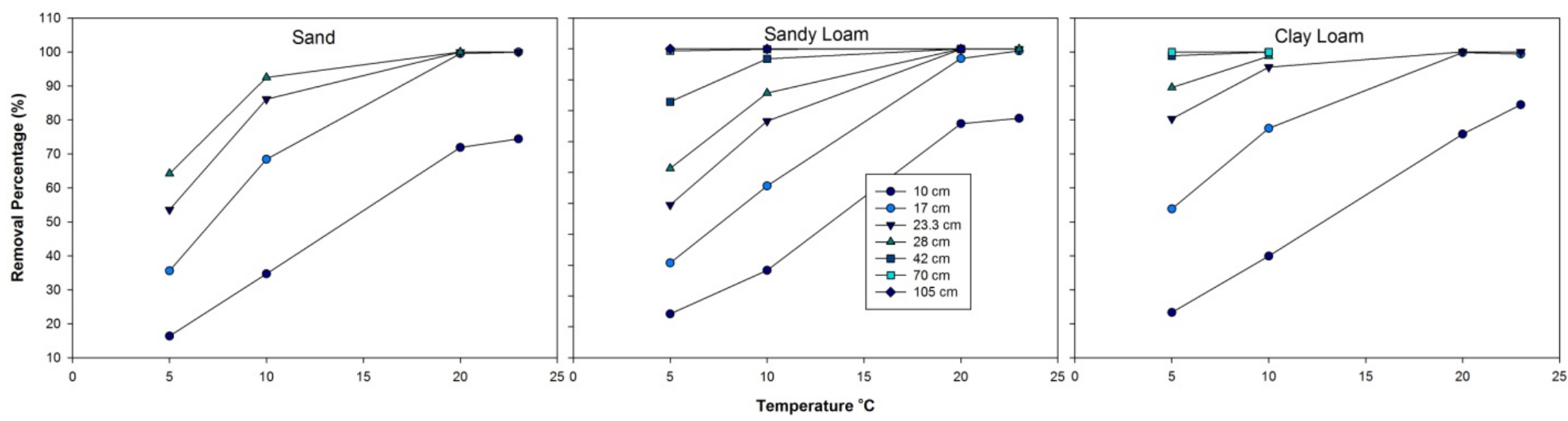




\title{
SUPPLEMENTAL MATERIAL
}

\section{Bacteria Transport in a Soil-Based Wastewater Treatment System under Simulated Operational and Climate Change Conditions}

\author{
Ivan Morales ${ }^{1 *}$, José A. Amador ${ }^{2}$ and Thomas Boving ${ }^{1,3}$ \\ ${ }^{1}$ Department of Civil and Environmental Engineering, ${ }^{2}$ Laboratory of Soil Ecology and \\ Microbiology, and ${ }^{3}$ Department of Geosciences, University of Rhode Island, Kingston, RI
}

Supplemental Table S1. Measured GFP E. coli die-off rates in soil and septic tank effluent (Morales et al., 2014).

\begin{tabular}{lll}
\hline \multirow{2}{*}{ Medium } & Die-off rate $\left(\mathbf{h}^{-\mathbf{1}}\right)$ & \\
\cline { 2 - 3 } & Measured & $\mathbf{R}^{\mathbf{2}}$ \\
\hline Sand & 0.0617 & 0.791 \\
Sandy loam & 0.0298 & 0.965 \\
Clay loam & 0.2476 & 0.965 \\
Septic tank effluent & 0.0824 & 0.891 \\
\hline
\end{tabular}

Supplemental Table S2. E. coli transport parameters derived from HYDRUS 2D/3D (Šimůnek et al., 2006; Morales et al., 2014).

\begin{tabular}{|c|c|c|c|c|c|c|}
\hline \multirow{2}{*}{ Micro-organism } & \multirow{2}{*}{ Soil type } & \multicolumn{4}{|c|}{ Transport parameters } & \multirow[t]{2}{*}{$\mathbf{R}^{2}$} \\
\hline & & $\operatorname{Sink}_{L}$ & Sink $_{S}$ & Attach & Detach & \\
\hline \multirow{4}{*}{ E. coli } & & $\left(h^{-1}\right)$ & $\left(h^{-1}\right)$ & $\left(h^{-1}\right)$ & $\left(h^{-1}\right)$ & \\
\hline & Sand & 0.0824 & 0.062 & 0.163 & 0.0044 & 0.91 \\
\hline & Sandy loam & 0.0824 & 0.0298 & 0.026 & 0.0199 & 0.83 \\
\hline & Clay loam & 0.0824 & 0.2476 & 0.078 & 0.0000001 & 0.99 \\
\hline
\end{tabular}

Notes: Sink $_{\mathrm{L}}$, aqueous phase die-off rate (STE); Sink $\mathrm{S}$, solid phase die-off rate; Attach, attachment rate; Detach, detachment rate. 


\title{
MANUSCRIPT - III: MODELING NITROGEN LOSSES IN CONVENTIONAL AND ADVANCED SOIL-BASED ONSITE WASTEWATER TREATMENT SYSTEMS
}

In preparation for submission in PLOS ONE

\author{
Ivan Morales $^{1 *}$, Jennifer Cooper ${ }^{2}$, José A. Amador $^{2 \uparrow}$, Thomas Boving ${ }^{1,3 \pi}$ \\ ${ }^{1}$ Department of Civil and Environmental Engineering, University of Rhode Island, Kingston, Rhode Island, \\ United States of America \\ ${ }^{2}$ Laboratory of Soil Ecology and Microbiology, University of Rhode Island, Kingston, Rhode Island, \\ United States of America \\ ${ }^{3}$ Department of Geosciences, University of Rhode Island, University of Rhode Island, Kingston, Rhode \\ Island, United States of America \\ *Corresponding author \\ E-mail: ivan_morales@my.uri.edu \\ E-mail: boving@uri.edu
}




\section{ABSTRACT}

Most of the non-point source nitrogen (N) load in rural areas is attributed to onsite wastewater treatment systems (OWTS). Nitrogen and its various chemical forms are considered environmental pollutants because they cause eutrophication, depleting the oxygen in water bodies. We simulated the fate and transport of $\mathrm{N}$ in three different types of OWTS drainfields, or soil treatment areas (STA), using 2D/3D HYDRUS software to develop a $\mathrm{N}$ transport and fate model. Experimental data from a laboratory mesocosm study, including soil moisture content and ammonia $\left(\mathrm{NH}_{4}\right)$ and nitrate $\left(\mathrm{NO}_{3}{ }^{-}\right)$ concentrations, were used to calibrate the model. A water content-dependent function was used to compute nitrification and denitrification rates. Three types of drainfields were simulated: (1) pipe-and-stone (P\&S), (2) pressurized shallow narrow drainfield (SND) and (3) Geomat (Geo), a variation of SND. The model was calibrated with acceptable goodness of fit between the observed and measured values. Average root mean square error (RSME) ranged from $0.18 \mathrm{mg} \mathrm{L}^{-1}$ to $2.88 \mathrm{mg} \mathrm{L}^{-1}$ for $\mathrm{NH}_{4}^{+}$and 4.45 $\mathrm{mg} \mathrm{L}^{-1}$ to $9.65 \mathrm{mg} \mathrm{L}^{-1}$ for $\mathrm{NO}_{3}^{-}$in all drainfield types. The calibrated model was used to estimate $\mathrm{N}$ fluxes for both conventional and advanced STAs. The model computed the $\mathrm{N}$ losses from nitrification and denitrification with little difference compared to measured concentrations in all STAs. The modeled $\mathrm{N}$ losses occurred mostly as $\mathrm{NO}_{3}{ }^{-}$in water outputs, accounting for more than $82 \%$ of $\mathrm{N}$ inputs in all drainfields. In addition, $\mathrm{N}$ losses as $\mathrm{N}_{2}$ were calculated for P\&S, SND and Geo. The simulated $\mathrm{N}_{2}$ was $10.4 \%$ and $9.7 \%$ of total $\mathrm{N}$ input concentration for SND and Geo, respectively. The highest $\mathrm{N}$ losses by denitrification were computed for the P\&S drainfield and accounted for $17.6 \%$ of the influent total N. These findings can help provide practitioners with guidelines to estimate 
$\mathrm{N}$ removal efficiencies for traditional and advanced OWTS, and predict $\mathrm{N}$ loads and spatial distribution for identifying non-point sources.

\section{INTRODUCTION}

Decentralized wastewater treatment systems, such as onsite wastewater treatment systems (OWTS), are engineeered technologies used for wastewater management to protect public health and prevent the environment from contamination. Onsite wastewater treatment systems integrate a septic tank, where solids removal takes place, and a soil treatment area (STA), or drainfield, where contaminants are attenuated and treated wastewater is safely infiltrated to recharge groundwater. Conventional OWTS treat domestic wastewater efficiently, removing 5-day biochemical oxygen demand $\left(\mathrm{BOD}_{5}\right)$, total suspended solids (TSS), pathogens and nutrients (i.e. N, P). However, these systems are not designed for removal of nitrogen $(\mathrm{N})[5,6]$ or emerging organic contaminants, such as personal care products and pharmaceuticals [7,8]. Furthermore, their use is limited in areas where a shallow water table lies beneath the STA, as well as in many coastal areas. Advanced OWTS are used in areas that are at risk of water use impairments (i.e., pathogen and nutrient contamination) because of a shallow-placed infiltrative surface.

A conventional OWTS consists of septic tank, distribution box and a gravity-dosed STA, which treats septic tank effluent (STE) as it infiltrates and percolates through the soil. The STA has a pipe-and-stone (P\&S) configuration: a horizontal drain constructed from perforated pipes located in an excavated trench backfilled with gravel or crushed stone. 
Advanced OWTS integrate engineered treatment units (i.e., sand filters) that provide additional treatment. The STE can then be pressure-dosed to a type of STA, known as a pressurized shallow narrow drainfields (PSND). In advanced and conventional OWTS, the STA is dosed with STE or advanced-treated effluent (ATE), and is usually installed $15-30 \mathrm{~cm}$ and $\sim 60 \mathrm{~cm}$ below the ground surface, respectively [9]. The shallow depth in the STA of advanced OWTS increases the vertical separation distance, or unsaturated zone, and enhances the potential for treatment before the effluent reaches the water table [10-12]. A thicker unsaturated zone increases the opportunity for $\mathrm{O}_{2}$ diffusion and attenuation of contaminants [13-16]. There are other advantages of PSND relative to conventional STAs. For example, pressurized systems disperse the effluent more uniformly over the STA, which avoids overloading (ponding) and supports complete infiltration [17]. A shallow drainfield also enhances the transformation of nutrients by microorganisms and their uptake by plants because effluent distribution takes place closer to the soil surface, within the root zone, where microbial activity is highest [11].

OWTS can be sources of surface and groundwater contamination and they are one of the top 10 probable sources of impairments in rivers, lakes, and coastal shoreline in U.S. [18]. Pathogens and nutrients are frequently cited causes of impairments in water bodies. Nitrogen is of particular concern because its presence in high concentrations may stress the functioning of surface and coastal water ecosystems. Approximately $32 \%$ of stream length have been reported to be stressed or affected by $\mathrm{N}$ in U.S. [19-21]. Excess $\mathrm{N}$ in coastal areas and some freshwater ecosystems can result in eutrophication, decreased dissolved oxygen levels and habitat degradation [19-21]. $\mathrm{N}$ in wastewater is found as organic nitrogen, ammonium $\left(\mathrm{NH}_{4}{ }^{+}\right)$, nitrate $\left(\mathrm{NO}_{3}{ }^{-}\right)$and nitrite $\left(\mathrm{NO}_{2}{ }^{-}\right)$[22]. The nitrogen 
speciation in OWTS effluent is dependent on the type of treatment processes. In conventional systems, the STE is typically composed of $10-30 \%$ organic nitrogen and 70 $90 \% \mathrm{NH}_{4}^{+}[9,23]$. The STA of advanced systems receives effluent from an advanced treatment system (ATE) such as a single-pass sand filter, where the concentration of $\mathrm{NH}_{4}{ }^{+}$is reduced and converted to $\mathrm{NO}_{3}{ }^{-}$. Therefore, $\mathrm{N}$ speciation in ATE is $18 \%$ organic $\mathrm{N}, 26 \% \mathrm{NH}_{4}^{+}$and $56 \% \mathrm{NO}_{3}^{-}[24]$.

As STE and ATE are loaded to the drainfield, $\mathrm{N}$ species can be transformed or removed in the soil below the infiltrative surface. Nitrogen transformations in conventional and advanced STAs have been studied to some extent [24,25]. Nitrification and denitrification are thought to be the main processes that contribute to $\mathrm{N}$ speciation in the drainfield [26]. In nitrification, $\mathrm{NH}_{4}{ }^{+}$is oxidized by autotrophic bacteria to $\mathrm{NO}_{3}{ }^{-}$in the STA under aerobic conditions. Nitrate can be subsequently reduced by heterotrophic denitrifying bacteria to nitrogen gas $\left(\mathrm{N}_{2}\right)$ or nitrous oxide $\left(\mathrm{N}_{2} \mathrm{O}\right)$, which results in net removal of $\mathrm{N}$ from wastewater.

The fate and transport of $\mathrm{N}$ in OWTS drainfield is a complex process controlled by many factors, including $\mathrm{pH}$, temperature, moisture content, carbon availability, and oxygen diffusion. Computer-aided numerical models have been developed to understand $\mathrm{N}$ dynamics in in the STA. A broad variety of models have been used that include OWTS as a $\mathrm{N}$ source, but most of these only simulate $\mathrm{NO}_{3}{ }^{-}$transport groundwater, but hydrodynamic processes (advection-dispersion) are not included [25-27].

Other researchers have used HYDRUS 1D, 2D and 3D models to predict the fate and transport of $\mathrm{N}$ in OWTS [28-31]. HYDRUS is a commercially-available computer 
program used to simulate water flow, solute and microbial transport [32], heat transport, and colloid transport in variably-saturated porous media [33,34]. For instance, Hassan [28] used HYDRUS 2D to simulate an onsite wastewater subsurface drip irrigation system (SDIS) dosed with pre-treated wastewater in a sequential batch reactor (SBR) . The wastewater was collected from a restaurant and contained oil and grease with high organic matter content. Together with a grease trap and aeration unit, the SBR was used as a pre-treatment unit, where $\mathrm{NH}_{4}{ }^{+}$was nitrified and entered the SDIS as $\mathrm{NO}_{3}{ }^{-} \mathrm{N}$. The model included $\mathrm{NO}_{3}{ }^{-}$transport, plant uptake, and denitrification in order to estimate an $\mathrm{N}$ mass balance for the SDIS-SBR system. In addition, soil water pressure head data was collected and modeled. Based on this model, it was estimated that $48 \%$ of $\mathrm{NO}_{3}{ }^{-}$was stored in the soil profile, $27 \%$ was taken up by plants, $22 \%$ removed by denitrification, and $0.4 \% \mathrm{NO}_{3}{ }^{-}$left with the drainage water.

Heatwole and McCray [29] used HYDRUS 1D to model fate and transport of $\mathrm{N}$ in a conventional STA. The model was developed to evaluate the concentration of $\mathrm{NO}_{3}{ }^{-}$ reaching groundwater using site-specific data and input transport parameters estimated from statistical distributions. The results showed that no $\mathrm{NH}_{4}{ }^{+}$was detected at $30-\mathrm{cm}$ depth below the infiltrative surface or deeper in the model domain. Also, $\mathrm{NO}_{3}{ }^{-}$ concentrations were predicted to be below maximum contaminant level $(\mathrm{MCL}=10 \mathrm{mg}$ $\mathrm{N} / \mathrm{L}$ ) when the median value for denitrification rate was applied.

HYDRUS 2D/3D was used to fit experimental soil pressure head and $\mathrm{N}$ and chloride $\left(\mathrm{Cl}^{-}\right)$ data collected from a conventional OWTS with a drainfield installed in a clay soil [30]. The model involved the application of an $\mathrm{N}$ transformation chain or non-equilibrium transport of $\mathrm{N}$ in sequential decay reactions $\left(\mathrm{NH}_{4}{ }^{+} \rightarrow \mathrm{NO}_{3}{ }^{-} \rightarrow \mathrm{N}_{2}\right)$ with water content- 
dependent, first-order transformation rates for nitrification and denitrification. Contrary to Heatwole and McCray [29], the model assumed that $\mathrm{N}$ decay occurs and aquifer recharge was considered. The authors computed $\mathrm{N}$ losses from the STA with the calibrated model. Based on a $\mathrm{N}$ mass balance, the model predicted that $52 \%$ of $\mathrm{N}$ was removed by denitrification. Furthermore, less than $5 \%$ of $\mathrm{N}$ loss accounted as plant uptake and change in $\mathrm{N}$ storage. The model [30] was then used by Radcliffe and Bradshaw [31] to evaluate OWTS hydraulic loading rates (HLR) and N transformations in 12 soil textural classes. Similar to the previous study [30], water flow and $\mathrm{N}$ and temperature dynamics were simulated in a 2-D drainfield trench for two years. It was observed that all HLRs values (range: 1.48 to $5.40 \mathrm{~cm} \mathrm{~d}^{-1}$ ) were suitable for all soil types except for the sandy clay textural class, where the trench was overloaded (HLR $=1.48$ $\mathrm{cm} \mathrm{d}^{-1}$ ). The predictions for denitrification losses varied widely among soil types, from $1 \%$ in sand to $75 \%$ in sandy clay. Leaching losses of $\mathrm{NO}_{3}{ }^{-}$were more significant than denitrification, ranging from $27 \%$ in sandy clay to $97 \%$ in sand. The variations in leaching losses were attributed to denitrification, limitations in water content, and the effect of HLRs on $\mathrm{N}$ transformation rates.

A limited number of studies have investigated the $\mathrm{N}$ fate, transport and removal mechanisms of Nin advanced STAs, including PSND or other systems that incorporate a secondary treatment unit [35-38]. None of these studies have numerically modeled $\mathrm{N}$ transformations in STAs dosed with advanced-treated effluent. Little is known about nitrification and denitrification rates in advanced STAs, and no modeling approach has been developed to simulate these transformation processes. In this manuscript, we addressed this knowledge gap with a calibrated HYDRUS 2D [33] model using soil 
moisture content and $\mathrm{N}$ speciation data collected from mesocosms representing a conventional P\&S drainfield and two types of shallow narrow drainfields, PSND and Geomat. We determined nitrification and denitrification rate coefficients for the three drainfield types and used this to estimate $\mathrm{N}$ losses from simulations and compared to actual experimental data. The information obtained from these models is expected to aide designers of OWTS and regulators to make informed decisions about the most effective treatment practicse for removal of $\mathrm{N}$ species in the STA.

\section{MATERIAL AND METHODS}

\section{Experimental setup}

Replicated mesocosms $(n=3)$ were engineered to mimic the soil treatment area and wastewater delivery system of a PSND, Geomat, and P\&S at a current temperature $\left(20{ }^{0} \mathrm{C}\right.$ $\pm 0.7)$ and water table separated $90 \mathrm{~cm}(\mathrm{PSND}$ and Geomat) or $30 \mathrm{~cm}(\mathrm{P} \& S)$ from the infiltrative surface [24]. Mesocosms consisted of polyvinyl chloride (PVC) pipes (0.15 m ID, $1.5 \mathrm{~m} \mathrm{H}$ ) containing undisturbed soil that is representative of the soil profile used for an STA of an OWTS in southern New England. Morphological, physical and chemical properties of the soil are listed in S1 Table.

Mesocosms were dosed with domestic wastewater based on accepted guidelines for frequency and volume of wastewater inputs for the State of Rhode Island. For P\&S mesocosms, STE was applied at a rate of $400 \mathrm{~mL} \mathrm{~d}^{-1}$ in two doses of $200 \mathrm{~mL}$ over $1.5 \mathrm{~h}$ every 12 hours. PSND and GEO mesocosms were dosed with SFE at a rate of $2 \mathrm{~L} \mathrm{~d}^{-1}$, in 42-mL doses over $15 \mathrm{~min}$ every $30 \mathrm{~min}$. The wastewater was dispersed $20 \mathrm{~cm}$ below 
ground surface for PSND, $25 \mathrm{~cm}$ for GEO and $84 \mathrm{~cm}$ for P\&S. The mesocosms were instrumented with probes to collect soil moisture and temperature data.

Effluent samples, along with wastewater inputs, were analyzed weekly for total N, ammonium and nitrate, and other water quality parameters. The physical, chemical and microbiological characteristics of STE and SFE are shown in S2 Table. Detailed information about soil mesocosm setup and water analysis methodology are summarized in Cooper et al. [24].

\section{Modeling approach}

HYDRUS 2D/3D version 2.0 was used to simulate water flow and solute transport in soils under variably-saturated conditions. The HYDRUS program numerically solves the Richards equation for saturated-unsaturated water flow (Eq. 1):

$$
\frac{\partial \theta}{\partial \mathrm{t}}=\frac{\partial}{\partial \mathrm{x}_{\mathrm{i}}}\left[\mathrm{K}\left(\mathrm{K}_{\mathrm{ij}}^{\mathrm{A}} \frac{\partial \mathrm{h}}{\partial \mathrm{x}_{\mathrm{j}}}+\mathrm{K}_{\mathrm{iz}}^{\mathrm{A}}\right)\right]-\mathrm{S}
$$

where $\theta$ is the volumetric water content $\left[\mathrm{L}^{3} \mathrm{~L}^{-3}\right], \mathrm{h}$ is the pressure head $[\mathrm{L}], \mathrm{S}$ is a sink term $\left[\mathrm{T}^{-1}\right]$, $\mathrm{xi}(\mathrm{i}=1,2)$ are the spatial coordinates $[\mathrm{L}], \mathrm{t}$ is time $[\mathrm{T}], \mathrm{K}_{\mathrm{ij}}^{\mathrm{A}}$ are components of a dimensionless anisotropy tensor $\mathrm{K}^{A}$, and $\mathrm{K}$ is the unsaturated hydraulic conductivity function $\left[\mathrm{LT}^{-1}\right]$ given by

$$
K(h, x, y, z)=K_{s}(x, y, z) K_{r}(h, x, y, z)
$$

where $\mathrm{K}_{\mathrm{r}}$ is the relative hydraulic conductivity and $\mathrm{K}_{\mathrm{s}}$ the saturated hydraulic conductivity $\left[\mathrm{LT}^{-1}\right]$. 
HYDRUS allows the user to select among several analytical models to describe the soil water retention and unsaturated hydraulic conductivity functions. In our model, the van Genuchten [39] equation was applied to compute the soil hydraulic properties (Eq. 3-5):

$$
\theta(h)=\theta_{r}+\frac{\theta_{s}-\theta_{r}}{\left[1+|-\alpha h|^{n}\right]^{m}}
$$

where $\alpha\left(\mathrm{L}^{-1}\right), m$ (dimensionless), and $n$ (dimensionless) are fitted parameters, $\theta(h)$ is the volumetric water content $\left(\mathrm{L}^{3} \mathrm{~L}^{-3}\right), \theta_{s}$ is the saturated volumetric water content $\left(\mathrm{L}^{3} \mathrm{~L}^{-3}\right)$, and $\theta_{r}$ is the residual volumetric water content $\left(\mathrm{L}^{3} \mathrm{~L}^{-3}\right)$. The unsaturated hydraulic conductivity function $K(h)\left(\mathrm{LT}^{-1}\right)$ is written as follows:

$$
\begin{gathered}
K(h)=K_{S} S_{e}^{l}\left[1-\left(1-S_{e}^{\frac{1}{m}}\right)^{m}\right]^{2} \\
S_{e}=\frac{\theta-\theta_{r}}{\theta_{s}-\theta_{r}}
\end{gathered}
$$

where $m=1-1 / n$ and $l$ is the pore connectivity parameter, which it is assumed to be about 0.5 [40]. The model permits the application of the convection - dispersion equation in the liquid phase to simulate solute transport and fate. Chemical equilibrium and linear adsorption is described by the following mass balance equation:

$$
\frac{\partial \theta \mathrm{c}}{\partial \mathrm{t}}+\rho \mathrm{K}_{\mathrm{d}} \frac{\partial \mathrm{c}}{\partial \mathrm{t}}=\frac{\partial}{\partial \mathrm{x}}\left(\theta \mathrm{D}_{\mathrm{ij}}^{\mathrm{w}} \frac{\partial \mathrm{c}}{\partial \mathrm{x}_{\mathrm{j}}}\right)+\frac{\partial}{\partial \mathrm{z}}\left(\theta \mathrm{D}_{\mathrm{ij}}^{\mathrm{w}} \frac{\partial \mathrm{c}}{\partial \mathrm{z}_{\mathrm{j}}}\right)-\frac{\partial \mathrm{q}_{\mathrm{x}} \mathrm{c}}{\partial \mathrm{x}}-\frac{\partial \mathrm{q}_{\mathrm{z}} \mathrm{c}}{\partial \mathrm{z}}-\mu \theta \mathrm{c}
$$

where $c$ is dissolved solution concentration $\left[\mathrm{ML}^{-3}\right], t$ is time $(\mathrm{T}), \mathrm{K}_{\mathrm{d}}$ is the adsorption coefficient $\left(\mathrm{L}^{3} \mathrm{M}^{-1}\right), \mu$ represents the solute transformation or degradation rate in the liquid phase, $x$ is the solute travel distance (L) and $z$ is depth $(\mathrm{L}) . \mathrm{D}^{\mathrm{w}}{ }_{\mathrm{ij}}$ is the dispersion 
coefficient tensor for the liquid phase $\left[\mathrm{L}^{2} \mathrm{~T}^{-1}\right], \theta$ is the volumetric water content $\left[\mathrm{L}^{3} \mathrm{~L}^{-3}\right], \rho$ is the bulk density of porous medium $\left[\mathrm{ML}^{-3}\right]$, and $q_{x}$ and $q_{z}$ is the specific discharge $\left[\mathrm{LT}^{-1}\right]$ along the horizontal and vertical direction, respectively.

\section{Model domain and boundary conditions}

The model domain was developed to resemble the engineered mesocosm columns, not only physically but also in terms of operational conditions. The geometry of the domain properties reproduced the two shallow and trench drainfields described previously [24]. The model domain consisted of a 2D vertical plane (x-z) (rectangular, $\mathrm{L}=15 \mathrm{~cm}, \mathrm{H}=137$ cm high) (Figure 3. 1). The infiltrative surface was placed below the top boundary that shaped the ground surface. PSND consists of lateral pipes that distribute the SFE by squirting it against a cover made of larger diameter pipe cut longwise. It is modeled by an arc that represents an impermeable half-pipe cover located above the drainfield. GEO comprises of a core of entangled plastic filaments and a pressure distribution pipe covered with a protective layer of geotextile fabric. Geomat was modeled by including a $1-\mathrm{cm}$ filament core layer and a $2.54-\mathrm{cm}$ diameter circle on the top, which simulates the distribution pipe. The $\mathrm{P} \& \mathrm{~S}$ model integrates a $30-\mathrm{cm}$ layer (crushed stone or gravel backfill) with an embedded $2.54-\mathrm{cm}$ diameter circle or simulated perforated pipe located $60 \mathrm{~cm}$ below the soil surface.

The native soil, used for the mesocosms, was described as a Bridgehampton silt loam (coarse-silty, mixed, active, mesic Typic Dystrudept) (S1 Table). The infiltrative surface was placed $20-25 \mathrm{~cm}$ below the ground surface for PSND and GEO (A horizon), and 84 $\mathrm{cm}$ (C horizon) for $\mathrm{P} \& \mathrm{~S}$. Based on field observations, two layers were used to simulate $\mathrm{B}$ (gravelly loamy sand) and C (gravelly coarse sand, $40-45 \%$ gravel) horizons. For the 
purpose of this study and because of their similarities in the particle size distribution, sublayers $B_{w}$ and $2 B_{w}$ were assumed to be $B$ horizon and modeled as one single layer.

Finite element mesh with a maximum element size of $3.90 \mathrm{~cm}$ was generated automatically with 478,537 and 614 nodes for P\&S, GEO and PSND, respectively. A denser grid was defined around the simulated distributed pipes and the PVC cover. Elements size in that area was $0.45 \mathrm{~cm}$. Observation nodes were located along the soil profile to compare the observed against modeled data. Two observation nodes were placed $15 \mathrm{~cm}$ and $30 \mathrm{~cm}$ below the infiltrative surface and one was located at the bottom of the model domain and one at the column outlet.

Atmospheric boundary condition was assigned to the top of the columns (Figure 3. 2). The sides and bottom of the column were treated as no-flux boundaries. As wastewater infiltrates, it accumulates on the bottom and flows out when the soil is saturated or a hanging water table is formed. In order to account for this condition, a seepage face boundary was selected for one of the nodes at the bottom right of each soil column (Figure 3. 2). In the HYDRUS model, this assumption is that the water is removed by overland flow when saturated conditions prevail [33].

\section{$\mathbf{N}$ transformation modeling}

Nitrogen losses in STA are attributed to $\mathrm{NH}_{4}^{+}$conversion to $\mathrm{NO}_{3}^{-}$or nitrification followed by reduction of $\mathrm{NO}_{3}{ }^{-}$to $\mathrm{N}_{2} \mathrm{O}$ or $\mathrm{N}_{2}$ through denitrification. Therefore, we developed a decay model to simulate the $\mathrm{N}$ species fate and transport in conventional and advanced STA in which $\mathrm{N}$ was assumed to be transformed as follows [26]: 


$$
\begin{gathered}
\mathrm{NH}_{4}^{+} \rightarrow \mathrm{NO}_{3}^{-} \rightarrow \mathrm{N}_{2} \\
\frac{\partial\left[\mathrm{NO}_{3}^{-}\right]}{\partial \mathrm{t}}=-\frac{\partial\left[\mathrm{NH}_{4}^{+}\right]}{\partial \mathrm{t}}=\mu
\end{gathered}
$$

where $\mu$ is described as the zero-order reaction rate for nitrification. $\mathrm{N}$ species were modeled using sequential decay reactions built into HYDRUS [41]. In this approach, the program provides nonlinear non-equilibrium reactions (adsorption-desorption) between the solid and liquid phases (soil-water interface) based on the two-site sorption concept $[42,43]$. It is considered that the sorption sites are composed of two fractions, sorption in one of the fractions is assumed to be instantaneous, while on the remaining site is timedependent. Also it is assumed that the solute transport takes place by convection and dispersion. The measured total $\mathrm{N}$ (TN) was modeled as an input concentration to include all $\mathrm{N}$ infiltrated in the drainfield. Thus, the influent organic $\mathrm{N}$ was considered to be transformed to $\mathrm{NH}_{4}{ }^{+}$through ammonification.

Several researchers have reported the water content dependency of nitrification and denitrification $[44,45]$. Nitrification is an aerobic process that occurs at low soil water content because high soil water content increases tortuosity and, as a result limits oxygen diffusion and the activity of nitrifying bacteria [46]. On the other hand, denitrification takes place under soil-saturated conditions which promotes anoxic conditions.. Thus, HYDRUS was modified to account for the effect of soil water content and aeration conditions on $\mathrm{N}$ transformation on OWTS. A water content dependency function was built in HYDRUS that allows computing of nitrification and denitrification rates at low water saturation or unsaturated conditions. The program incorporates the water content dependency function implemented in DRAINMOD-N2 [47], an agricultural computer 
program used to model $\mathrm{N}$ transformation and the impact of water content. DRAINMODN2 simulates nitrification and denitrification using Michaelis-Menten kinetics [48]. For nitrification the model uses a stepwise function to model the influence of nitrification inhibitors on decay rates. Denitrification is modeled as a function of the organic content decrease with depth [49]. The following expression describes the nitrification rate:

$$
\mu_{n i t}=\mu_{n i t, \text { max }}\left(\frac{C_{N_{4}}}{\mu_{m, N H_{4}}+C_{N H_{4}}}\right) f_{t} f_{s w}
$$

where $\mu_{n i t}$ is the calculated nitrification rate, $\mu_{\text {nit, } \max }$ is the maximum nitrification rate, $C_{N H 4}$ is the ammonium-nitrogen concentration, and $K_{m, N H 4}$ is the half-saturation constant, which is the ammonium-nitrogen concentration at which the nitrification rate is half its maximum value. The value of $f_{s w}$ is soil-water content dependency functions (Eqn. 10):

$$
f_{s w}= \begin{cases}f_{s}+\left(1-f_{s}\left(\frac{1-S}{1-S_{h}}\right)^{e_{1}}\right. & S_{h}<S \leq 1 \\ f_{w p}+\left(1-f_{w p}\right)\left(\frac{1-S_{w p}}{S_{l}-S_{w p}}\right)^{e_{2}} & S_{w p}<S \leq S_{l}\end{cases}
$$

where $f_{s w}$ varies between 0 and 1 . The term, $f_{s}$ is the value of $f_{s w}$ at full saturation, $f_{w p}$ is the value of $f_{s w}$ at the wilting point, $S$ is the water-filled pore space (or relative saturated water content), $S_{h}$ is the upper saturation boundary for optimal nitrification, $S_{l}$ is the lower saturation boundary for optimal nitrification, $s w p$ is the saturation level at the wilting point, and $e_{2}$ and $e_{3}$ are fitting exponents. The denitrification rate equation included in the modified HYDRUS version is written as follows: 


$$
\mu_{\text {denit }}=\mu_{\text {denit }, \max }\left(\frac{C_{\mathrm{NO}_{3}}}{K_{m, N O_{3}}+C_{\mathrm{NO}_{3}}}\right) f_{t} f_{s w, d n} f_{z}
$$

where $\mu_{\text {denit }}$ is the denitrification rate, $\mu_{\text {denit,max }}$ is the maximum denitrification rate, $C_{N O 3}$ is the nitrate-nitrogen concentration, and $K_{m, N O 3}$ is the half-saturation constant, which is the nitrate-nitrogen concentration at which the denitrification rate is half its maximum value. The terms $f_{t}$, and $f_{z}$ are temperature-dependency, and carbon dependency functions, respectively.

$$
\begin{gathered}
f_{t}=\exp \left[-0.5 \beta T_{o p t}+\beta T\left(1-\frac{0.5 T}{T_{o p t}}\right)\right] \\
f_{z t}=e^{-a z} \\
f_{s w, d n}= \begin{cases}0 & S<S_{d n} \\
\left(\frac{S-S_{d n}}{1-S_{d n}}\right)^{f} & S \geq S_{d n}\end{cases}
\end{gathered}
$$

$f_{t}$ varies between 0 and $1, T$ is the temperature, $T_{o p t}$ is the optimum temperature for nitrification, $\beta$ and $a$ are fitting parameters, and $z$ is depth below the infiltrative surface. The term $f_{s w, d n}$ is the water content-dependency function, $s_{d n}$ is a threshold saturation value for denitrification, $s$ is the actual soil saturation, and $f$ is a fitting exponent.

\section{Calibration and parameter sensitivity}

Model calibration was carried out to determine input parameter values for obtaining the best fit between the predicted and measured soil data. The model was calibrated by coupling HYDRUS with UCODE, a computer program used to estimate parameters through inverse modeling by nonlinear regression [50]. The nonlinear regression problem 
is solved by minimizing a weighted least squares objective function with respect to the parameter values using a modified Gauss-Newton method.

A sensitivity analysis in UCODE was performed to identify which of the parameters influenced the model output results and their uniqueness. Composite scaled sensitivities (CSSs) were calculated to identify the influence of the observed data on the estimation of a parameter. CSS is the measure of the total amount of information provided by the observations to estimate one parameter. Larger CSS values indicate that those parameters are likely to be estimated more precisely with the proposed model and observations. The ratio of the CSS of a parameter to the maximum CSS was used to compare relative sensitivity among estimated parameters. Parameters with CSS ratio less than 0.01 are not sensitive and denote that a regression will not converge. Therefore, in some cases, parameters with CSS ratio $<0.01$ were excluded from the inverse modeling process.

The model was calibrated by fitting water content and nitrogen species data $\left(\mathrm{NH}_{4}{ }^{+}\right.$and $\mathrm{NO}_{3}{ }^{-}$concentration). HYDRUS water flow and solute transport modules were applied to complete the calibration. First, water content data were fitted to obtain the soil hydraulic parameters and evaluate the impact of moisture content on N transformation. Secondly, $\mathrm{NH}_{4}^{+}$and $\mathrm{NO}_{3}^{-}$concentration data were used to determine the nitrification and denitrification rates, and estimate $\mathrm{N}$ losses.

The model was initially run near saturation to reach steady water flow conditions in a shorter simulation time. Therefore, initial average pressure heads were set to $-50 \mathrm{~cm}$ for the entire model soil profile. Atmospheric boundary conditions were assigned to the top of the model domain or simulated soil surfaces. The minimum permissible pressure was 
assumed to be $-1,000 \mathrm{~cm}$. No precipitation, evapotranspiration or root uptake was included in the simulated $\mathrm{N}$ transformation.

Hydraulic loading rates were modeled by assigning a variable flux boundary condition in each of the soil mesocosms. For PSND, it was assumed that wastewater was distributed uniformly over the entire infiltrative surface. For GEO and P\&S, the variable flux boundary was located below the distribution pipe. SFE and STE deliveries were modeled as applied in the mesocosm lab-experiments.

Initial values for soil hydraulic parameters were determined by the computer program Rosetta [51] which is part of HYDRUS. The software estimates soil water retention by implementing hierarchical pedotransfer functions (PTFs) based on soil textural classes. Fitting parameter values were assigned to the entangled plastic filaments (GEO) and crushed stone $(\mathrm{P} \& \mathrm{~S})$ systems. Both materials were considered highly-conductive $\left(\mathrm{K}_{\mathrm{s}}=\right.$ $3,000 \mathrm{~cm} \mathrm{day}^{-1}$ ) with low porosity and residual water content that was similar to a coarse gravel soil. Initial parameter values for native soils were estimated using Rosetta [51] and fitted with UCODE, whereas values for the plastic filaments and gravel layers were kept fixed. Initial $\mathrm{N}$ transformation rates were selected from McCray [26] and initial $\mathrm{NH}_{4}{ }^{+}$and $\mathrm{NO}_{3}{ }^{-}$soil concentration were set to zero. Water dependency function parameters were selected from McCray et al. [52]. Finally, the model was run for 3-months (90 days). The predicted $\mathrm{N}$ species concentrations were computed to estimate a $\mathrm{N}$ balance produced by each of the three OWTS.

The best fit between the predicted and observed data were evaluated the root mean squared error (RMSE) (eq. 15). 


$$
\text { RMSE }=\sqrt{\frac{\sum_{i=1}^{n}\left(\hat{y}_{i}-y_{i}\right)^{2}}{n}}
$$

where $\hat{y}_{i}$ is the predicted value, $y_{i}$ is the observed value, and $n$ is the number of observations. A RMSE value closer to zero indicates the best of fit to observed data.

\section{RESULTS AND DISCUSSION}

\section{Water content}

The model was calibrated using soil moisture data to simulate the unsaturated soil profile beneath the infiltrative surface, and to account for moisture changes associated with $\mathrm{N}$ transformation processes. Given that variations in water content around the measured moisture data were minimal, the mesocoms simulations were under steady state conditions. The soil hydraulic parameters $\left(\theta_{r}, \theta_{s}, \alpha, \mathrm{K}_{\mathrm{s},} n\right.$ and $\left.l\right)$ were determined for each of the soil layer (silt loam and gravelly-coarse sand); only the pore connectivity parameter value was not calibrated or changed ( $l$ was equal to 0.5 , as recommended [33]). Ten parameters were calibrated for the advanced OWTS technologies and five for the conventional one. In advanced STAs, the measured water content $\left(\mathrm{cm}^{-3} \mathrm{~cm}^{-3}\right)$ ranged from 0.11 to 0.13 and 0.02 to 0.05 at $15 \mathrm{~cm}$ and $30 \mathrm{~cm}$ below the infiltrative surface, respectively. Even though the intact soil cores were collected in close vicinity to each

other, water content variations were expected at greater because of the increasing influence of variable physical properties on soil moisture and water flow with depth. Also, the amount of water retained in the upper soil layer was expected to affect the hydraulic properties of the deeper soil layers. This more heterogeneous behavior of the 
soil system is illustrated for one of the three PSND mesocosms that showed higher water content $\left(0.23 \mathrm{~cm}^{-3} \mathrm{~cm}^{-3}\right)$ at the $15-\mathrm{cm}$ depth compared to the other $\left(0.11\right.$ to $\left.0.13 \mathrm{~cm}^{-3} \mathrm{~cm}^{-3}\right)$. These variations are indicative of soils with low residual and high saturated water content characteristics.

Overall, the model results showed a good fit between the observed and simulated water content data for PSND, GEO and P\&S (Figure 3. 3). For PSND and GEO, RMSE values range from 0.0010 and 0.0075 for silt loam and gravelly-coarse sand, indicating good agreement between the simulated and measured data. The goodness-of-fit is illustrated in Figure 3. 3, where the model output data were described by a straight line during the entire period of simulation at both observation nodes $(15-\mathrm{cm}$ and $30-\mathrm{cm}$ depths). Compared to PSND and GEO dosing regiments, P\&S mesocosms were dosed with wastewater every $12 \mathrm{~h}$, which produced a comparably drier soil profile and resulted in longer times of unsaturated flow between doses. Thus, variations in soil moisture content were observed between dosing events, with soil moisture values varying by a factor of two. The water content peaked immediately after dosing $\left(0.03 \mathrm{~cm}^{-3} \mathrm{~cm}^{-3}\right.$ to 0.05 $\left.\mathrm{cm}^{-3} \mathrm{~cm}^{-3}\right)$ and dropped quickly $\left(0.01 \mathrm{~cm}^{-3} \mathrm{~cm}^{-3}\right.$ to $\left.0.02 \mathrm{~cm}^{-3} \mathrm{~cm}^{-3}\right)$ between doses. Under steady state conditions, the model was reproduced those fluctuations with acceptable goodness of fit (RMSE: $0.0033 \mathrm{~cm}^{-3} \mathrm{~cm}^{-3}$ to $0.0044 \mathrm{~cm}^{-3} \mathrm{~cm}^{-3}$ ) in all $\mathrm{P} \& S$ drainfields.

The water content data were modeled under the effect of a simulated hanging water table at the bottom of the mesocosms, where the seepage face boundary (Figure 3. 4) caused this part of the model domain to remain saturated once the system was at steady state. The seepage boundary condition allows the water to flow out of the model space when the pressure head value reaches $0 \mathrm{~cm}$ or the soil is saturated. The calibrated 
retention curve parameters are shown in Table 3. 1. The calibrated values differed among soil layers, which indicate that the properties of the soil at the infiltrative surface were different from the underlying soil, likely due to differences in soil texture and structure. Based on the soil moisture data, the silt loam was less conductive with higher saturated water contents. The underlying soil (gravelly-coarse sand) for the PSND and GEO was simulated with $\mathrm{K}_{\mathrm{sg}}$ values ranging from 908.88 to $942.48 \mathrm{~cm} \mathrm{day}^{-1}$, which were $21 \%$ to $44 \%$ compared favorably to reported values for sandy soil [53,54]. Variations in hydraulic conductivity values have to be expected among soil textures, particularly for the gravelly-coarse sand. These values were likely the result of the presence of a significant amount of gravel, which accounted for $40 \%$ to $45 \%$ of the soil by weight. These differences in physical properties affect soil properties directly and influence hydraulic properties and water flow. An average hydraulic conductivity of $4.51 \mathrm{~cm} \mathrm{day}^{-1}$ was computed for the P\&S drainfield mesocosms (Table 3. 1). It is most likely that a biomat developed over time above the infiltrative surface, which provides unsaturated conditions and a reduced saturated hydraulic conductivity (Figure 3.4).

\section{Sensitivity analysis}

For the sensitivity analysis of the PSND and GEO, five soil hydraulic parameters $\left(\theta_{r}, \theta_{s}\right.$, $\alpha, \mathrm{K}_{\mathrm{s}}$ and $n$ ) for each of the two horizons (silt loam and gravelly-coarse sand) were calibrated simultaneously (10 parameters total). For P\&S, the moisture data for the gravelly-coarse sand was calibrated with the 5 parameters mentioned above. The sensitivity of soil moisture to soil hydraulic properties for each of the mesocosms and soil horizons is shown in Table 3. 2. Most of the selected parameters were significantly sensitive (CSS $\geq 0.01)$ to the water content data. In most advanced STAs, the silt loam 
soil properties were sensitive to the simulated soil moisture. Not unexpectedly, the soil properties were found most important for the calibration of the hydraulic parameters along the soil profile. Generally, the most sensitive parameters were $\theta_{s s}$ and $n_{s}$. Conversely, $K_{s s}, \theta_{r s}, \theta_{r g}$ and $K_{s g}$ were not significant or least sensitive parameters to the moisture data. For $\mathrm{P} \& \mathrm{~S}$, the saturated and residual water content $\left(\theta_{r g}\right.$ and $\left.\theta_{s g}\right)$ were very important parameters determining the soil moisture distribution along the profile. Also, the hydraulic conductivity $\left(K_{s g}\right)$ (range: 908.88 to $942.48 \mathrm{~cm} \mathrm{day}^{-1}$ ) was more sensitive compared to PSND and GEO (CSS $=0.21$ to 0.25$)$.

In one of the PSND columns (Table 3. 2, column \#3) the $K_{s g}$ was not a sensitive parameter to the fitted water content data $(\mathrm{CSS}<0.01)$. In this mesocosm, the water content of the silt loam was almost two times higher $\left(0.23 \mathrm{~cm}^{-3} \mathrm{~cm}^{-3}\right)$ than those values observed for the other two PSND columns $\left(0.11 \mathrm{~cm}^{-3} \mathrm{~cm}^{-3}\right.$ to $\left.0.13 \mathrm{~cm}^{-3} \mathrm{~cm}^{-3}\right)$. These variations are likely linked to soil heterogeneities and affected the sensitivity of $K_{s g}$ as reflected in the model output data.

\section{Nitrogen transport and fate}

Nitrification and denitrification were modeled using a water content-dependent function to account for changes in oxygen diffusion and availability in the mesocosms. The function uses water-filled pore space or relative saturation to mimic soil aeration during water infiltration [49]. Based on this approach, $\mathrm{NO}_{3}{ }^{-}$production is achieved with a water-filled pore space (WFPS) of 0.20 and the maximum nitrification rate is reached when WFPS is more than 0.35 . Denitrification takes place when WFPS is more than 0.60 and the highest $\mathrm{N}_{2}$ gas production is observed at saturation (WFPS $\left.=1.00\right)[55,56]$. Linn and Doran [56] reported that organic carbon decomposition associated with $\mathrm{N}$ 
mineralization and immobilization occurs when WFPS ranges from 0.5 to 0.6 and near saturation as well. Therefore, WFPS variation may affect the denitrification rates in the soil drainfield. However, it must be emphasized that the aqueous solution used in those experiments $[55,56]$ had a higher dissolved oxygen concentration compared to the STE and ATE used in this study. These observations show that the relationship between WFPS and relative rate of microbial nitrification and denitrification may be affected during $\mathrm{N}$ transformation, and nitrification and denitrification may occur at lower WFPS. The nitrification and denitrification rate coefficients were computed using Eq. 9 through 14, and parameter values were selected from literature data [52]. The fitted parameter values for the water-content dependent transformation rates are shown in Table 3. 3. Initially, the model was adjusted until the best fit between the observed and predicted data was achieved. As a result, the parameters for nitrification and denitrification dependency functions are median values that best reproduced the observed data [52].

The fitted water content was important to elucidate the $\mathrm{N}$ transformation and decay in the mesocosms and the application of the water content dependent functions. The results showed that the WFPS was higher than 0.27 (P\&S gravelly-coarse sand) in all drainfields types (Table 3.4). This indicates that sufficient oxygen is available for nitrification to proceed. Compared to the gravelly-coarse sand, the silt loam material had the highest values for the modeled WFPS in both PSND and GEO (0.64 and 0.74, respectively). A similar value (0.76) was reported by Bradshaw et al. [30] when simulating nitrification and denitrification rates from an OWTS installed in a claytextured soil using pressure head and $\mathrm{NH}_{4}{ }^{+}$and $\mathrm{NO}_{3}{ }^{-}$concentration data to simulate the system. Their model converted the pressure heads into water content values to calculate 
the actual WFPS of the drainfield. It also captured the effect of seasonal changes (dry and wet weather) on $\mathrm{N}$ transformation. They reported that the computed WFPS was adequate for nitrification to occur.

Our results are consistent with what is expected for the soil types and the hydraulic properties of the mesocosm materials. The data indicate that nitrification occurred in the first few centimeters below the infiltrative surface. Nitrate production in all drainfields and at shallow depths (top $15 \mathrm{~cm}$ ) is likely caused by the oxidation of ammonia by ammonia-oxidizing (e.g. Nitrosomonas spp.) and nitrifying bacteria (e.g. Nitrobacter spp.) [24]. However, no bacteria analysis of the soil was carried out in this study. The predicted and measured $\mathrm{NH}_{4}{ }^{+}$concentrations for all drainfield types are shown in Figure 3.5. The model output data show a good fit with the measured $\mathrm{NH}_{4}{ }^{+}$ concentration in output water, with RMSE values range between 0.18 and $2.88 \mathrm{mg} \mathrm{L}^{-1}$. The maximum $\mathrm{NH}_{4}{ }^{+}$concentration was found to be near the infiltrative surface (first 15 $\mathrm{cm}$ ) and decreased with depth along the soil profile. The model results showed that the $\mathrm{NH}_{4}{ }^{+}$was almost completely transformed at the $30-\mathrm{cm}$ depth. This is consistent with other researchers, who observed a similar trend in $\mathrm{N}$ transformation experiments in OWTS drainfields $[29,57,58]$. Moreover, the lowest measured and modeled $\mathrm{NH}_{4}{ }^{+}$ concentrations were observed in the outflow, where almost no $\mathrm{NH}_{4}{ }^{+}$was detected. The reduction of $\mathrm{NH}_{4}{ }^{+}$concentration with depth is associated with the complete $\mathrm{NH}_{4}{ }^{+}$ transformation through nitrification.

Measured $\mathrm{NO}_{3}{ }^{-}$concentration data were calibrated in all three STA types. The $\mathrm{NO}_{3}^{-}$concentration in SFE inputs and water exiting the mesocoms were measured. Nitrate tended to increase with depth along the soil profile in all mesocosms, with the 
highest concentration detected in the outlet (seepage boundary). For ATE, the model output included $\mathrm{NO}_{3}{ }^{-}$already in the influent water as well as $\mathrm{NO}_{3}{ }^{-}$produced in situ from $\mathrm{NH}_{4}{ }^{+}$conversion. In PSND and GEO, influent total $\mathrm{N}$ included $\mathrm{NO}_{3}{ }^{-}$and $\mathrm{NH}_{4}{ }^{+}$. Some of the nitrate resulted from $\mathrm{NH}_{4}{ }^{+}$being nitrified in the sand filter that preceded the treatment system from which the ATE was collected from. The model suggests that the remaining $\mathrm{NH}_{4}{ }^{+}$will be transformed to $\mathrm{NO}_{3}{ }^{-}$in the drainfield.

The predicted $\mathrm{NO}_{3}{ }^{-}$concentrations showed an acceptable goodness-of-fit with the observed data, with RMSEs that ranges from $4.45 \mathrm{mg} \mathrm{L}^{-1}$ to $9.65 \mathrm{mg} \mathrm{L}^{-1}$ in all STA types (Figure 3.6). Lower RMSE values were observed for predicted $\mathrm{NO}_{3}{ }^{-}$data for PSND and GEO compared to P\&S. The ATE was assumed to be more uniformly distributed over the infiltrative surface in the PSND and GEO in the absence of an overlying layer (i.e., crushed stone) that influences the water flow and solute transport.

\section{Nitrification and denitrification rates}

The processes involved in $\mathrm{N}$ transformation and removal are mainly nitrification and denitrification. In addition, $\mathrm{NH}_{4}{ }^{+}$sorption to soil can affect the fate and transport of $\mathrm{N}$ in some OWTS drainfields. Because of the low sorption capacity of the soils used in drainfield mesocosms (Supplemental Table $\mathrm{S} 1$ ), $\mathrm{NH}_{4}{ }^{+}$sorption was not simulated in this model. Therefore, all $\mathrm{NH}_{4}{ }^{+}$moves with soil water and can be readily nitrified. Average simulated nitrification and denitrification zero-order reaction rates were computed to analyze the $\mathrm{N}$ dynamics and conversion in all drainfield types (Table 3. 5). The nitrification rates ranged from $0.5 \mathrm{mg} \mathrm{L}^{-1} \mathrm{~d}^{-1}$ to $574 \mathrm{mg} \mathrm{L}^{-1} \mathrm{~d}^{-1}$ and were similar to zeroorder rate values previously reported by McCray et al. [26]. 
Geza et al. [59] developed a tool for predicting the fate and transport of nitrogen in STAs (STUMOD), which uses nitrification rates as an input parameter. A median value of $56 \mathrm{mg} \mathrm{N} \mathrm{L}^{-1} \mathrm{~d}^{-1}$ is used as default. This value is similar to nitrification rates modeled herein. Overall, the advanced OWTS drainfields showed higher nitrification rates compared to P\&S. For PSND, the average zero-order nitrification rates for silt loam and gravelly coarse sand were $45.25 \mathrm{mg} \mathrm{N} \mathrm{L}^{-1} \mathrm{~d}^{-1}$ and $49.19 \mathrm{mg} \mathrm{N} \mathrm{L}^{-1} \mathrm{~d}^{-1}$, respectively. Lower values were computed for GEO $\left(2.17 \mathrm{mg} \mathrm{N} \mathrm{L}^{-1} \mathrm{~d}^{-1}\right.$ and $25.88 \mathrm{mg} \mathrm{N} \mathrm{L}^{-1} \mathrm{~d}^{-1}$ for silt loam and gravelly-coarse sand, respectively) and the model results showed that some nitrification occurred in the entangled plastic filaments $\left(25.88 \mathrm{mg} \mathrm{N} \mathrm{L}^{-1} \mathrm{~d}^{-1}\right)$. Nitrate production at the interface may be attributed to high oxygen diffusion and SFE aeration during infiltration. Apparently, the plastic filaments enhanced the interaction between the soil and SFE by increasing the oxygen transfer. The average nitrification rates were 3.83 mg N L ${ }^{-1} \mathrm{~d}^{-1}$ in the gravelly coarse sand for the P\&S. Nitrification took place at a rate of $12.10 \mathrm{mg} \mathrm{N} \mathrm{L}^{-1} \mathrm{~d}^{-1}$ in the crushed stone and was 0.5 times lower than that computed by the model for GEO plastic filaments. This indicates that the presence of a more conductive layer on the top of the native soil provides an additional treatment zone for $\mathrm{N}$ removal. Furthermore, the higher $\mathrm{NH}_{4}{ }^{+}$transformation rates in the advanced STAs suggest that the drainfield placement at a shallower depth is more effective for nitrification than the conventional systems, likely because of a larger volume of unsaturated soil available for treatment.

Denitrification was not very significant in any of the OWTS. Denitrification rate values were one to three orders of magnitude lower than nitrification rates (from 0.01 to $0.44 \mathrm{mg} \mathrm{N} \mathrm{L}^{-1} \mathrm{~d}^{-1}$ ). Tucholke et al. [60] reported higher zero-order denitrification rates, 
with values between 0.033 and $127 \mathrm{mg} \mathrm{N} \mathrm{L}^{-1} \mathrm{~d}^{-1}$. However, those values [60] were obtained under fully saturated conditions (WFPS $=100 \%$ ). Because unsaturated conditions prevailed in all mesocosms discussed herein, denitrification may have been restricted, since denitrification requires anaerobic conditions to proceed [53] and anaerobic conditions are more likely under saturated flow conditions.

Relative to each other, denitrification rates were higher in P\&S than GEO and PSND. This finding was consistent with the experimental results presented in [24], where denitrification was higher in P\&S compared to the other STAs. Besides anaerobic conditions, denitrification requires organic carbon to proceed [52]. Because ATE has a low organic carbon content, it may have limited the extent of denitrification in the advanced drainfield mesocosms. This is consistent with [24].

\section{$\mathrm{N}$ losses and comparison between simulated and real systems}

Average modeled $\mathrm{N}$ losses were calculated and compared with the experimental data from all of the advanced and conventional drainfield mesocoms. The calculations were based on the 90-day simulation period and accounted for all $\mathrm{N}$ species produced. An $\mathrm{N}$ mass balance was calculated from the modeled $\mathrm{N}$ species for influent and effluent water. In $\mathrm{P} \& \mathrm{~S}$, the modeled effluent $\mathrm{N}$ was comprised of dissolved $\mathrm{NO}_{3}{ }^{-}(82.72 \%)$ and $\mathrm{NH}_{4}^{+}(1.41 \%)$. In GEO and PSND, the modeled effluent $\mathrm{N}$ speciation consisted of 89$91 \% \mathrm{NO}_{3}{ }^{-}$and $0.23-0.44 \% \mathrm{NH}_{4}{ }^{+}$. The model results indicate that the total $\mathrm{N}$ losses as $\mathrm{N}_{2}$ were $10.44 \%, 9.65 \%, 17.60 \%$ for PSND, GEO and P\&S, respectively. There were discrepancies between the computed and observed $\mathrm{NO}_{3}{ }^{-}$data, particularly for the $\mathrm{N}$ removal in $\mathrm{P} \& \mathrm{~S}$. Some measured $\mathrm{NO}_{3}{ }^{-}$data points are higher and the computed $\mathrm{NO}_{3}{ }^{-}$data were underestimated by the model. It is likely that not all organic $\mathrm{N}$ was converted to 
$\mathrm{NH}_{4}{ }^{+}$and as a result, less $\mathrm{NH}_{4}{ }^{+}$was nitrified (for our modeling approach, it was assumed that organic $\mathrm{N}$ has been completely transformed to $\mathrm{NH}_{4}{ }^{+}$before entering the treatment system). Organic $\mathrm{N}$ was found to account for $14 \%$ to $16 \%$ [24] of the total $\mathrm{N}$ in the effluent water in $\mathrm{P} \& \mathrm{~S}$, which is a significant amount for $\mathrm{N}$ loss . Also, a fraction of the influent organic $\mathrm{N}$ is likely non-biodegradable or recalcitrant (not amenable to ammonification), which means it might not be transformed in the treatment system, passing through the drainfield unchanged. For GEO and PSND, the modeled $\mathrm{N}$ losses occurred mostly as $\mathrm{NO}_{3}{ }^{-}(90.75 \%$ and $88.45 \%$, respectively). No significant amount of $\mathrm{NH}_{4}{ }^{+}$was observed during the 90 -days simulation period (ranging from 0.23 to $1.41 \%$ for all drainfield types). Nitrogen losses as $\mathrm{N}_{2}$ were more evident in P\&S compared to the advanced technologies.

\section{CONCLUSIONS}

A model was developed to predict the $\mathrm{N}$ fate, transport and transformation in a conventional P\&S drainfield and in two types of shallow narrow drainfields (PSND and GEO). The model was calibrated using water content, $\mathrm{NH}_{4}{ }^{+}$and $\mathrm{NO}_{3}{ }^{-}$concentration data. From these inputs, water flow and solute transport parameters were determined. Nitrification and denitrification rates were computed as function of the soil water content and the WFPS. The model was capable to determine nitrification and denitrification zeroorder rates with acceptable goodness-of-fit between the observed and simulated data. These results allowed quantification the $\mathrm{N}$ losses in all OWTS drainfield types and an estimation of the $\mathrm{N}$ species fluxes. This information is useful to better understand the $\mathrm{N}$ transport and transformation mechanisms and to identify potential contamination sources of groundwater. 


\section{ACKNOWLEDGEMENTS}

We thank Dr. Mengistu Geza at Colorado School of Mines for his technical support and

guidance. This study was funded by USDA Hatch Multi-State Project NE-1045. 


\section{REFERENCES}

1. Adams MH. Bacteriophages. Bacteriophages. 1959. p. 592.

2. Lepore, B., \& Barak P. A colorimetric microwell method for determining bromide concentrations. Soil Sci Soc Am J. 2009;73:1130-6.

3. Pinheiro LB, Gibbs MD, Vesey G, Smith JJ, Bergquist PL. Fluorescent reference strains of bacteria by chromosomal integration of a modified green fluorescent protein gene. Appl Microbiol Biotechnol. 2008;77:1287-95.

4. Turco RF. Detection and enumeration of coliform bacteria in soil. Methods of soil analysis: Microbial and biochemical properties. Madison, WI; 1994. p. 145-59.

5. Giblin AE, Gaines AG. Nitrogen inputs to a marine embayment: the importance of groundwater. Biogeochemistry. 1999 Jun 1;10(3):309-28.

6. Harden HS, Roeder E, Hooks M, Chanton JP. Evaluation of onsite sewage treatment and disposal systems in shallow karst terrain. Water Res. 2008 May;42(10-11):2585-97.

7. Swartz CH, Reddy S, Benotti MJ, Yin H, Barber LB, Brownawell BJ, et al. Steroid Estrogens, Nonylphenol Ethoxylate Metabolites, and Other Wastewater Contaminants in Groundwater Affected by a Residential Septic System on Cape Cod, MA. Environ Sci Technol. American Chemical Society; 2006 Aug 18;40(16):4894-902.

8. Standley L., Swartz C, Rudel RA, Attfield KR, J. C, Erickson M, et al. Wastewater-contaminated Groundwater as a Source Of Endogenous Hormones and Pharmaceuticals to Surface Water Ecosystems. 2008 [cited 2015 Aug 24]; Available from: http://sei-us.org/publications/id/66

9. Tyler, E.J., Laak, R., McCoy, E., Sandhu SS. The Soil as a treatment system. Proceedings of the Second National Home Sewage Treatment Symposium. St. Joseph, MI: ASAE; 1977. p. 5-77.

10. Hargett DL. Performance assessment of low pressure pipe wastewater injection systems. 4th National Symposium on Individual and Small Community Sewage Systems. St. Thomas, MI; 1985. p. 131-43.

11. Stewart, L.W. and Reneau RB. Shallowly placed, low pressure distribution system to treat domestic wastewater in soil with fluctuating high water tables. J Environ Qual. 1988;(17):499-504. 
12. Reneau RB, Hagedorn C, Degen MJ. Fate and Transport of Biological and Inorganic Contaminants from On-Site Disposal of Domestic Wastewater. J Environ Qual. 1989;135-44.

13. Anderson, D.L., Otis, R.J., McNeillie, J.I., Apfel RA. In-situ lysimeter investigation of pollutant attenuation in the vadose zone of a fine sand. Proceedings of the Seventh International Symposium on Individual and Smaill Community Sewage Systems. St. Joseph, MI: ASAE; 1994. p. 209-18.

14. Powelson DK, Gerba CP. Virus removal from sewage effluents during saturated and unsaturated flow through soil columns. Water Res. 1994;28(10):2175-81.

15. Stevik TK, Aa K, Ausland G, Hanssen JF. Retention and removal of pathogenic bacteria in wastewater percolating through porous media: A review. Water Research. 2004. p. 1355-67.

16. Birkham TK, Hendry MJ, Wassenaar LI, Mendoza CA. A transient model of vadose zone reaction rates using oxygen isotopes and carbon dioxide. Vadose Zo J. 2007;6:67-76.

17. Carlile BL. Use of shallow, low pressure injection systems in large and small installations. In NI McClelland (ed) Proceedings of the 6th National Conference on Individual Onsite Wastewater Systems. Ann Harbor, MI: National Sanitation Foundation; 1980. p. 371-85.

18. U.S. Environmental Protection Agency. Watershed Assessment, Tracking \& Environmental Results [Internet]. 2015 [cited 2003 May 20]. Available from: http://ofmpub.epa.gov/waters10/attains_nation_cy.control

19. US Environmental Protection Agency. Wadeable Streams Assessment: A Collaborative Survey of the Nation's Streams. Office of Water, US Environmental Protection Agency, Washington DC. 2006.

20. Loomis GW, Dow DB, Stolt MH, Green LT, Gold AJ. Evaluation of innovative onsite wastewater treatment systems in the green hill pond watershed, Rhode Island - A NODP II project update. On-Site Wastewater Treat Proc. 2001;506-15.

21. Brady NC, Weil RR. The nature and properties of soils. Macmillan Publishing CoNew York. 2002. 960 p.

22. Burks, D.B. and Minnis MM. Onsite Wastewater Treatment Systems. Madison, WI: Hogart House, Ltd.; 1994. 248 p.

23. Siegrist, R.L., Tyler, E.J., Jenssen PD. Design and Performance of Onsite Wastewater Soil Absorption Systems. National Research Needs Conference: Risk- 
Based Decision Making for Onsite Wastewater Treatment. Palo Alto, CA: EPRI Report; 2001.

24. Cooper JA, Loomis GW, Kalen D V, Amador JA. Evaluation of Water Quality Functions of Conventional and Advanced Soil-Based Onsite Wastewater Treatment Systems. J Environ Qual. 2015 Feb;

25. Beal CD, Gardner EA, Menzies NW. Process, performance, and pollution potential: A review of septic tank-soil absorption systems. Australian Journal of Soil Research. 2005. p. 781-802.

26. McCray JE, Kirkland SL, Siegrist RL, Thyne GD. Model parameters for simulating fate and transport of on-site wastewater nutrients. Ground Water. 2005. p. $628-39$.

27. Valiela I, Bowen JL, Kroeger KD. Assessment of models for estimation of landderived nitrogen loads to shallow estuaries. Appl Geochemistry. 2002;17(7):93553.

28. Hassan G, Reneau RB, Hagedorn C, Jantrania AR. Modeling Effluent Distribution and Nitrate Transport through an On-Site Wastewater System. 2008 Sep;1937-48.

29. Heatwole KK, McCray JE. Modeling potential vadose-zone transport of nitrogen from onsite wastewater systems at the development scale. J Contam Hydrol. 2007;91(1-2):184-201.

30. Bradshaw JK, Radcliffe DE, Šimůnek J, Wunsch A, McCray JE. Nitrogen Fate and Transport in a Conventional Onsite Wastewater Treatment System Installed in a Clay Soil: A Nitrogen Chain Model. Vadose Zo J. 2013 Aug;12(3):1-20.

31. Radcliffe DE, Bradshaw JK. Model Test of Proposed Loading Rates for Onsite Wastewater Treatment Systems. 2014;(6):97-107.

32. Morales I, Atoyan JA, Amador JA, Boving T. Transport of pathogen surrogates in soil treatment units: Numerical modeling. Water (Switzerland). 2014;6(4):818-38.

33. Simunek J, Genuchten M Van, Sejna M. The HYDRUS software package for simulating the two-and three-dimensional movement of water, heat, and multiple solutes in variably-saturated media. Technical manual. 2012.

34. Šejna M, van Genuchten MT, Šimůnek J. Development and Applications of the HYDRUS and STANMOD Software Packages and Related Codes. Vadose Zone Journal. 2008. p. 587.

35. Holden, S.A., Stolt, M.H., Loomis, G.W., Gold AJ. Seasonal variation in nitrogen leaching from shallow narrow drainfields. In: Mankin, editor. Proceedings of the 
Tenth International Symposium on Individual and Small Community Sewage Systems. St. Joseph, MI: ASAE; 2004. p. 432-40.

36. Holden SA. The effectiveness of shallow-narrow drainfields to treat domestic wastewater. University of Rhode Island; 2004.

37. Gill LW, O'Súlleabháin C, Misstear BDR, Johnston PJ. The Treatment Performance of Different Subsoils in Ireland Receiving On-Site Wastewater Effluent. J Environ Qual. 2007;(6):1843-55.

38. Gill L, O'Luanaigh N, Johnston P, Misstear BDR, O'Suilleabhain C. Nutrient loading on subsoils from on-site wastewater effluent, comparing septic tank and secondary treatment systems. Water Res. 2009;43(10):2739-49.

39. Van Genuchten MT. A Closed-form Equation for Predicting the Hydraulic Conductivity of Unsaturated Soils1. Soil Sci Soc Am J. 1980;44:892-8.

40. Mualem Y. A new model for predicting the hydraulic conductivity of unsaturated porous media. Water Resour Res. 1976;12(3):513-22.

41. Šimůnek, J.van Genuchten MT. Numerical model for simulating multiple solute transport in variably-saturated soils. In: Wrobel, L., Latinopoulos P, editor. Water Pollution III: Modelling, Measurement, and Prediction. Southampton, UK:

Computation Mechanics Publication, Ashurst Lodge, Ashurst; 1995. p. 21-30.

42. Selim HM, Schulin R, Flühler H. Transport and Ion Exchange of Calcium and Magnesium in an Aggregated Soil. Soil Sci Soc Am J. 1987;51(4):876.

43. Van Genuchten MT, Wagenet RJ. Two-Site/Two-Region Models for Pesticide Transport and Degradation: Theoretical Development and Analytical Solutions. Soil Sci Soc Am J. 1989;53(5):1303.

44. Grant RF. Mathematical modelling of nitrous oxide evolution during nitrification. Soil Biol Biochem. 1995;27(9):1117-25.

45. Bollmann A, Conrad R. Acetylene blockage technique leads to underestimation of denitrificatlon rates in oxic soils due to scavenging of intermediate nitric oxide. Soil Biol Biochem. 1997;29(7):1067-77.

46. Millington RJ, Quirk JP. Transport in porous media. Trans 7th int Congr Soil Sci. 1960;1:97-106.

47. Youssef MA, Youssef MA, Skaggs RW, Skaggs RW, Chescheir GM, Chescheir GM, et al. Drainmod - n ii. Society. 2005;48(2):611-26. 
48. Malhi SS, McGill WB. Nitrification in three Alberta soils: effects of temperature, moisture and substrate concentration. Soil Biol Biochem. 1982;14(4):393-9.

49. Brevé MA. Modeling the movement and fate of nitrogen in artificially drained soils. Ph.D. diss., North Carolina State University, Raleigh, N.C.; 1994.

50. Poeter EP, Hill MC. UCODE, a computer code for universal inverse modeling. Comput Geosci. 1999;25(4):457-62.

51. Schaap MG, Leij FJ, Van Genuchten MT. Rosetta: A computer program for estimating soil hydraulic parameters with hierarchical pedotransfer functions. J Hydrol. 2001;251(3-4):163-76.

52. McCray, J., M. Geza, K. Lowe, T. Boving, D. Radcliffe, M. Tucholke, A. Wunsch, S. Roberts, J. Amador, J. Atoyan, J. Drewes, D. Kalen GL. Quantitative Tools to Determine the Expected Performance of Wastewater Soil Treatment Units: Guidance Manual. 2010.

53. Brooks, R. H., Corey AT. Properties of porous media affecting fluid flow. J Irrig Drain Div. 1966;2(1992):61-90.

54. Van Genuchten MT. A Closed-form Equation for Prediccting Hydraulic Conductivity of Unsaturated Soils. Soil Sci Soc Am J. 1980;44(5):892-8.

55. Doran, J. W., Mielke, L.N., Stamatiadis S. Microbial activity and N cycling as regulated by soil water-filled pore space. Tillage and traffic in crop production Proc 11th Int Soil Tillage Res Organization. 1988. p. 49-54.

56. Linn DM, Doran JW. Effect of Water-Filled Pore Space on Carbon Dioxide and Nitrous Oxide Production in Tilled and Nontilled Soils1. Soil Science Society of America Journal. 1984. p. 1267.

57. Fischer EA. Nutrient Transformation and Fate During Intermittent Sand Filtration of Wastewater. MS Thesis, Colorado School of Mines, Golden, CO.; 1999.

58. Beach DNH. Infiltration of wastewater in sand columns. MS Thesis, Colorado School of Mines, Golden, CO; 2001.

59. Geza M, Lowe K, McCray J. STUMOD—a Tool for Predicting Fate and Transport of Nitrogen in Soil Treatment Units. Environ Model Assess. Springer International Publishing; 2014;19(3):243-56.

60. Tucholke, M. B., McCray, J. E., Thyne, G. D., Waskom RM. Variability in denitrification rates: literature review and analysis. National Onsite Wastewater Recycling Association 16th Annual Technical Education \& Exposition Conference. Baltimore, MD: NOWRA, Santa Cruz, CA; 2007. 
61. Sexstone AJ, Revsbech NP, Parkin TB, Tiedje JM. Direct Measurement of Oxygen Profiles and Denitrification Rates in Soil Aggregates1. Soil Science Society of America Journal. 1985. p. 645.

62. Bitton G. Wastewater Microbiology: Fourth Edition. Wastewater Microbiology: Fourth Edition. 2010. 


\section{TABLES}

Table 3. 1 Calibrated soil hydraulic parameters for the simulated advanced and conventional drainfield mesocosms. Values are means $\pm \mathrm{SD}(\mathrm{n}=3)$

\begin{tabular}{|c|c|c|c|c|c|}
\hline \multirow[b]{2}{*}{ Texture } & \multirow[b]{2}{*}{ Parameter } & \multirow[b]{2}{*}{ Units } & \multicolumn{3}{|c|}{ STA Type } \\
\hline & & & PSND & GEO & P\&S \\
\hline \multirow{5}{*}{ Silt loam } & $\theta_{r s}$ & $\mathrm{~cm}^{3} \mathrm{~cm}^{-3}$ & $0.025 \pm 0.002$ & $0.024 \pm 0.000$ & - \\
\hline & $\theta_{s s}$ & $\mathrm{~cm}^{3} \mathrm{~cm}^{-3}$ & $0.203 \pm 0.030$ & $0.181 \pm 0.017$ & - \\
\hline & $n_{s}$ & - & $2.289 \pm 0.590$ & $2.282 \pm 0.513$ & - \\
\hline & $K_{s s}$ & cm day $^{-1}$ & $220.02 \pm 51.03$ & $252.43 \pm 19.43$ & - \\
\hline & $\alpha_{s}$ & - & $0.0847 \pm 0.097$ & $0.0182 \pm 0.003$ & - \\
\hline \multirow{5}{*}{$\begin{array}{l}\text { Gravelly - } \\
\text { Coarse sand }\end{array}$} & $\theta_{r g}$ & $\mathrm{~cm}^{3} \mathrm{~cm}^{-3}$ & $0.013 \pm 0.001$ & $0.014 \pm 0.001$ & $0.012 \pm 0.001$ \\
\hline & $\theta_{s g}$ & $\mathrm{~cm}^{3} \mathrm{~cm}^{-3}$ & $0.063 \pm 0.034$ & $0.138 \pm 0.001$ & $0.068 \pm 0.034$ \\
\hline & $n_{g}$ & - & $4.037 \pm 0.412$ & $4.282 \pm 0.174$ & $3.731 \pm 0.687$ \\
\hline & $K_{s g}$ & $\mathrm{~cm}_{\text {day }}{ }^{-1}$ & $908.88 \pm 26.82$ & $942.48 \pm 5.430$ & $4.513 \pm 0.19$ \\
\hline & $\alpha_{g}$ & - & $0.0205 \pm 0.005$ & $0.0189 \pm 0.001$ & $0.0838 \pm 0.0440$ \\
\hline
\end{tabular}


Table 3. 2 Composite scale sensitivity ratios to the measured soil moisture data for the silt loam and gravelly-coarse sand soils for PSND, GEO and P\&S.

\begin{tabular}{llllllllll}
\hline & PSND & \multicolumn{9}{c}{ GEO } & \multicolumn{7}{c}{ P\&S } \\
\hline Parameter & $\mathbf{1}$ & $\mathbf{2}$ & $\mathbf{3}$ & $\mathbf{4}$ & $\mathbf{5}$ & $\mathbf{6}$ & $\mathbf{7}$ & $\mathbf{8}$ & $\mathbf{9}$ \\
\hline$\theta_{r s}$ & 0.08 & 0.09 & 0.01 & 0.06 & 0.14 & 0.08 & - & - & - \\
$\theta_{s s}$ & 1.00 & 1.00 & 1.00 & 1.00 & 0.96 & 1.00 & - & - & - \\
$n_{s}$ & 0.32 & 0.41 & 0.44 & 0.59 & 0.47 & 0.73 & - & - & - \\
$K_{s S}$ & 0.09 & 0.13 & 0.08 & 0.08 & 0.10 & 0.12 & - & - & - \\
$\alpha_{s}$ & 0.43 & 0.35 & 0.01 & 0.24 & 0.56 & 0.15 & - & - & - \\
$\theta_{r g}$ & 0.08 & 0.08 & 0.02 & 0.07 & 0.10 & 0.08 & 0.89 & 0.64 & 0.17 \\
$\theta_{s g}$ & 0.30 & 0.11 & 0.11 & 0.31 & 0.69 & 0.38 & 1.00 & 1.00 & 1.00 \\
$n_{g}$ & 0.22 & 0.08 & 0.02 & 0.26 & 0.44 & 0.31 & 0.46 & 0.66 & 0.61 \\
$K_{s g}$ & 0.07 & 0.04 & 0.00 & 0.06 & 0.06 & 0.06 & 0.24 & 0.21 & 0.25 \\
$\alpha_{g}$ & 0.39 & 0.32 & 0.09 & 0.43 & 1.00 & 0.53 & 0.15 & 0.04 & 0.02 \\
\hline
\end{tabular}


Table 3. 3 Fitted parameters for the nitrification and denitrification water contentdependent function.

\begin{tabular}{ccccccc|cr}
\hline \multicolumn{7}{c|}{ Nitrification } & \multicolumn{2}{c}{ Denitrification } \\
\hline $\mathbf{f}_{\mathbf{w p}}$ & $\mathbf{f}_{\mathbf{s}}$ & $\mathbf{S}_{\mathbf{w p}}$ & $\mathbf{S}_{\mathbf{l}}$ & $\mathbf{S}_{\mathbf{h}}$ & $\mathbf{e}_{\mathbf{2}}$ & $\mathbf{e}_{\mathbf{3}}$ & $\mathbf{S}_{\mathbf{d n}}$ & $\mathbf{e}_{\mathbf{1}}$ \\
\hline 0.000 & 0.000 & 0.154 & 0.665 & 0.809 & 2.267 & 1.104 & 0.000 & 2.86 \\
\hline
\end{tabular}


Table 3. 4 Modeled water-filled pore space for all STA types.

\begin{tabular}{lcc}
\hline STA type & Silt loam & $\begin{array}{c}\text { Gravelly- } \\
\text { coarse sand }\end{array}$ \\
\hline PSND & $0.64 \pm 0.06$ & $0.41 \pm 0.05$ \\
GEO & $0.74 \pm 0.15$ & $0.56 \pm 0.15$ \\
P\&S & & $0.27 \pm 0.02$ \\
\hline
\end{tabular}


Table 3. 5 Average zero-order nitrification and denitrification rates for the selected soils and materials in advanced and conventional drainfield mesocosms. Values are means \pm $\mathrm{SD}(\mathrm{n}=3)$.

\begin{tabular}{|c|c|c|c|c|c|c|}
\hline \multirow[b]{2}{*}{ Material } & \multicolumn{3}{|c|}{ Nitrification rates } & \multicolumn{3}{|c|}{ Denitrification rates } \\
\hline & PSND & GEO & P\&S & PSND & GEO & P\&S \\
\hline & \multicolumn{6}{|c|}{$\mathrm{Mg} \mathrm{L}^{-1} \mathrm{~d}^{-1}$} \\
\hline Silt loam & $45.25 \pm 2.12$ & $2.17 \pm 0.09$ & - & $0.17 \pm 0.12$ & $0.04 \pm 0.01$ & - \\
\hline $\begin{array}{c}\text { Gravelly- } \\
\text { coarse } \\
\text { sand }\end{array}$ & $49.19 \pm 2.24$ & $24.46 \pm 1.06$ & $3.83 \pm 3.42$ & $1.31 \pm 0.96$ & $0.31 \pm 0.10$ & $0.36 \pm 0.17$ \\
\hline Geomat & - & $25.88 \pm 1.12$ & - & - & $0.01 \pm 0.00$ & - \\
\hline $\begin{array}{l}\text { Crushed } \\
\text { stone }\end{array}$ & - & - & $12.10 \pm 3.72$ & - & - & $0.44 \pm 0.21$ \\
\hline
\end{tabular}




\section{FIGURES}

Figure 3. 1 Model domain and porous material distribution for PSND, GEO and pipe and stone. All dimensions are in $\mathrm{cm}$.

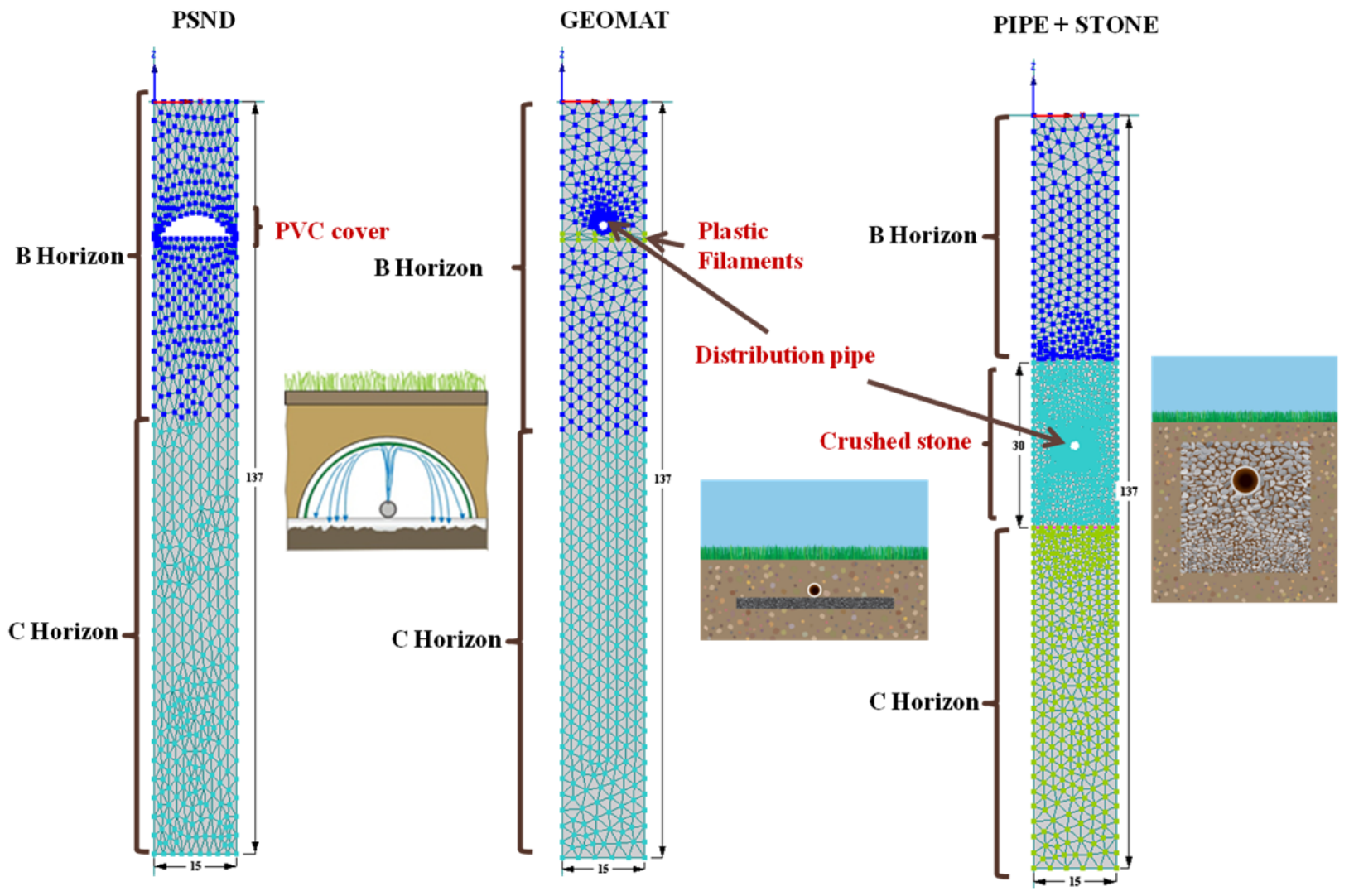


Figure 3. 2 Boundary conditions for (a) PSND, (b) GEOMAT and (c) Pipe and stone soil drainfield mesocosms.
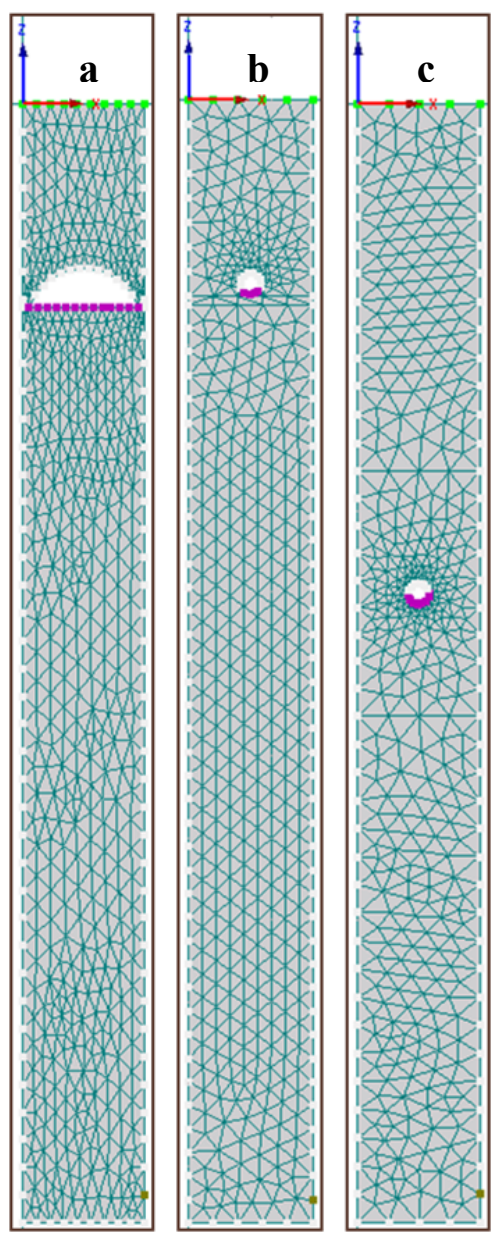

Atmospheric boundary

Variable flux

$\square$ No flux

Seepage face 
Figure 3. 3 Observed and simulated water content for (a) PSND, (b) GEOMAT and (c) Pipe and stone drainfield mesocosms. Root mean square error is included as a measure of the goodness-of-fit between predicted and observed data.

a)
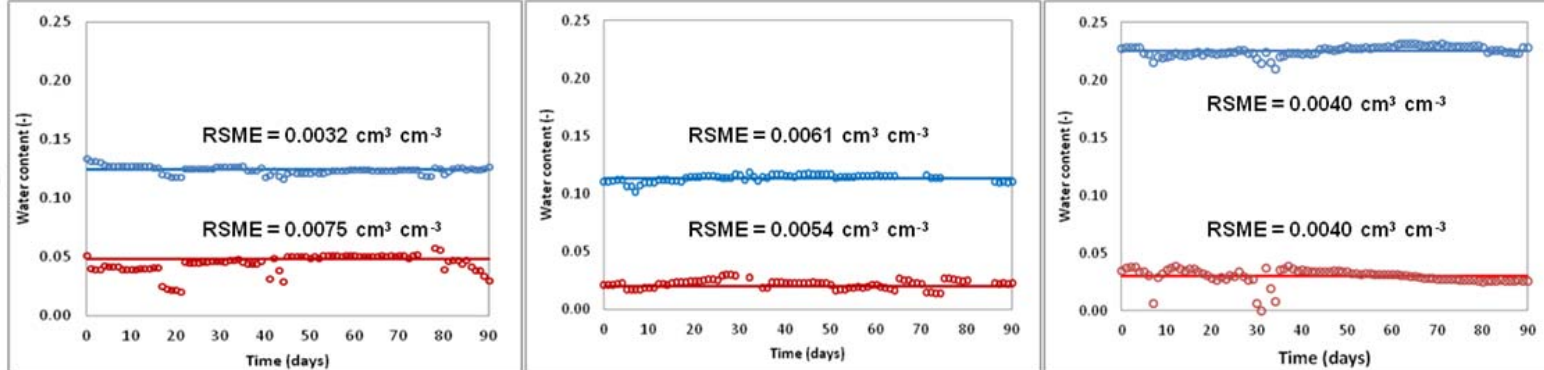

b)
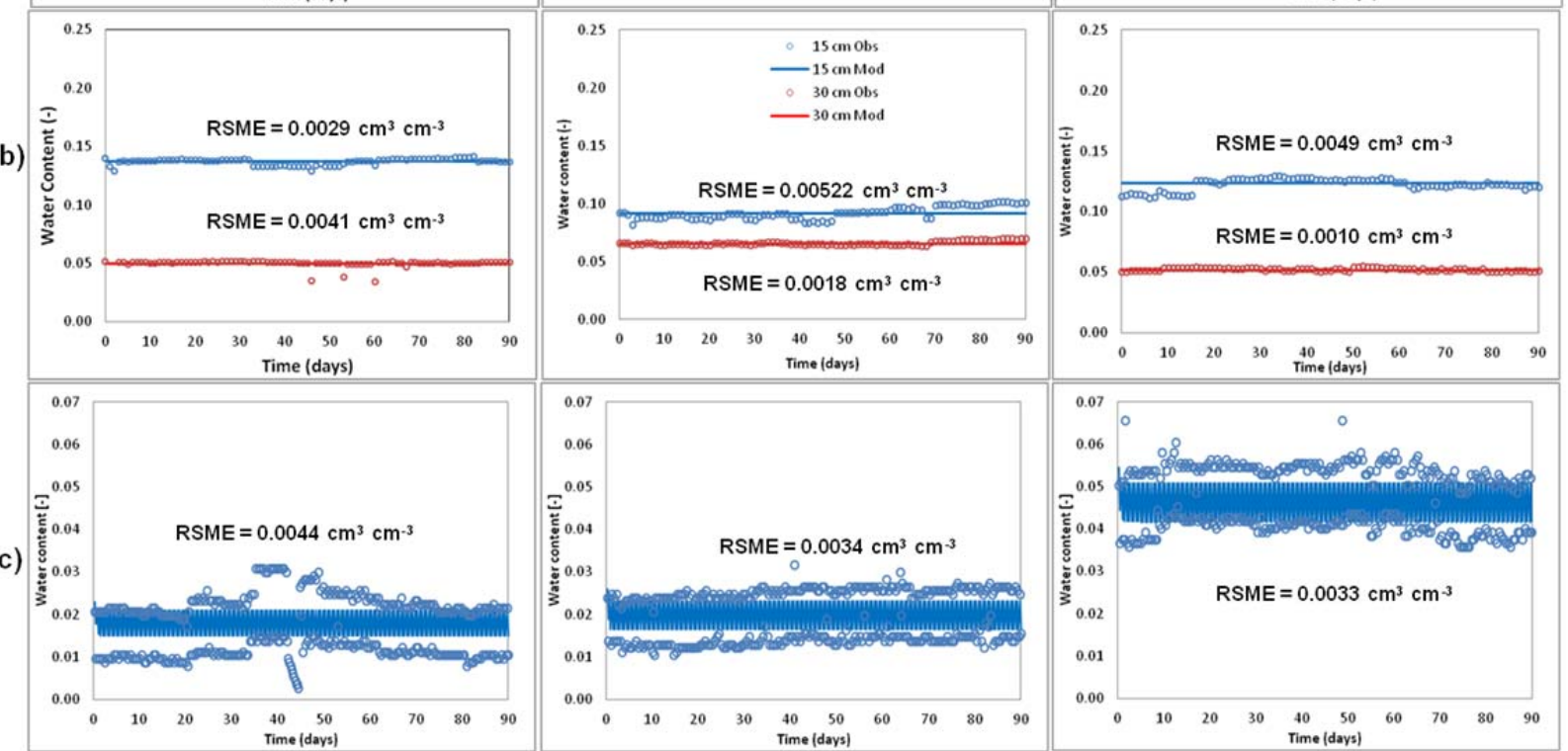
Figure 3. 4 Pressure head distribution as a result of the seepage boundary condition to simulate a hanging water table at the bottom of the mesocosms. At steady state, pressure head values are close to zero, which indicates that area is near or under saturation conditions.

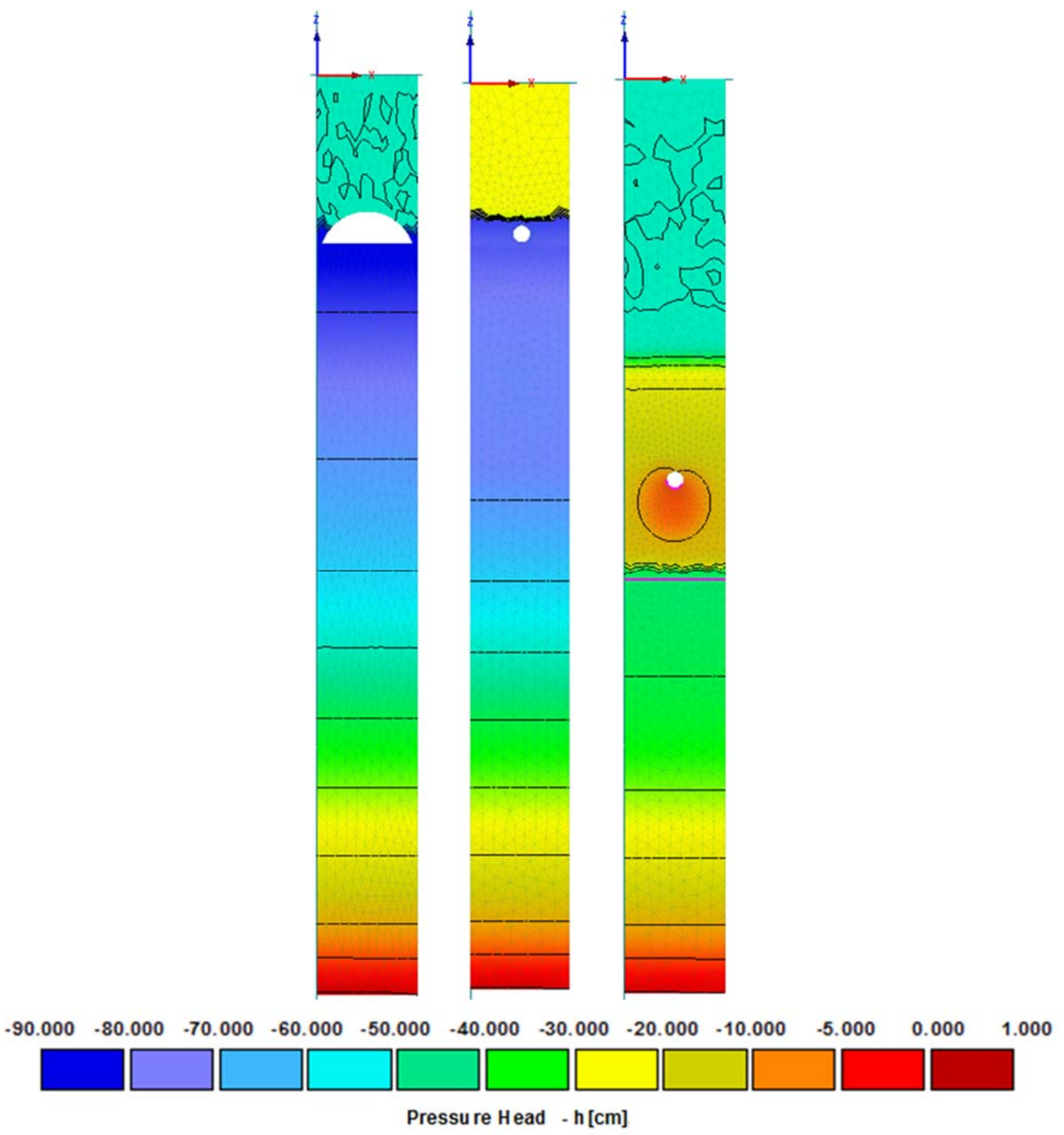


Figure 3. 5 Predicted and measured $\mathrm{NH}_{4}{ }^{+}$concentrations for (a) PSND, (b), GEO and (c) P\&S.
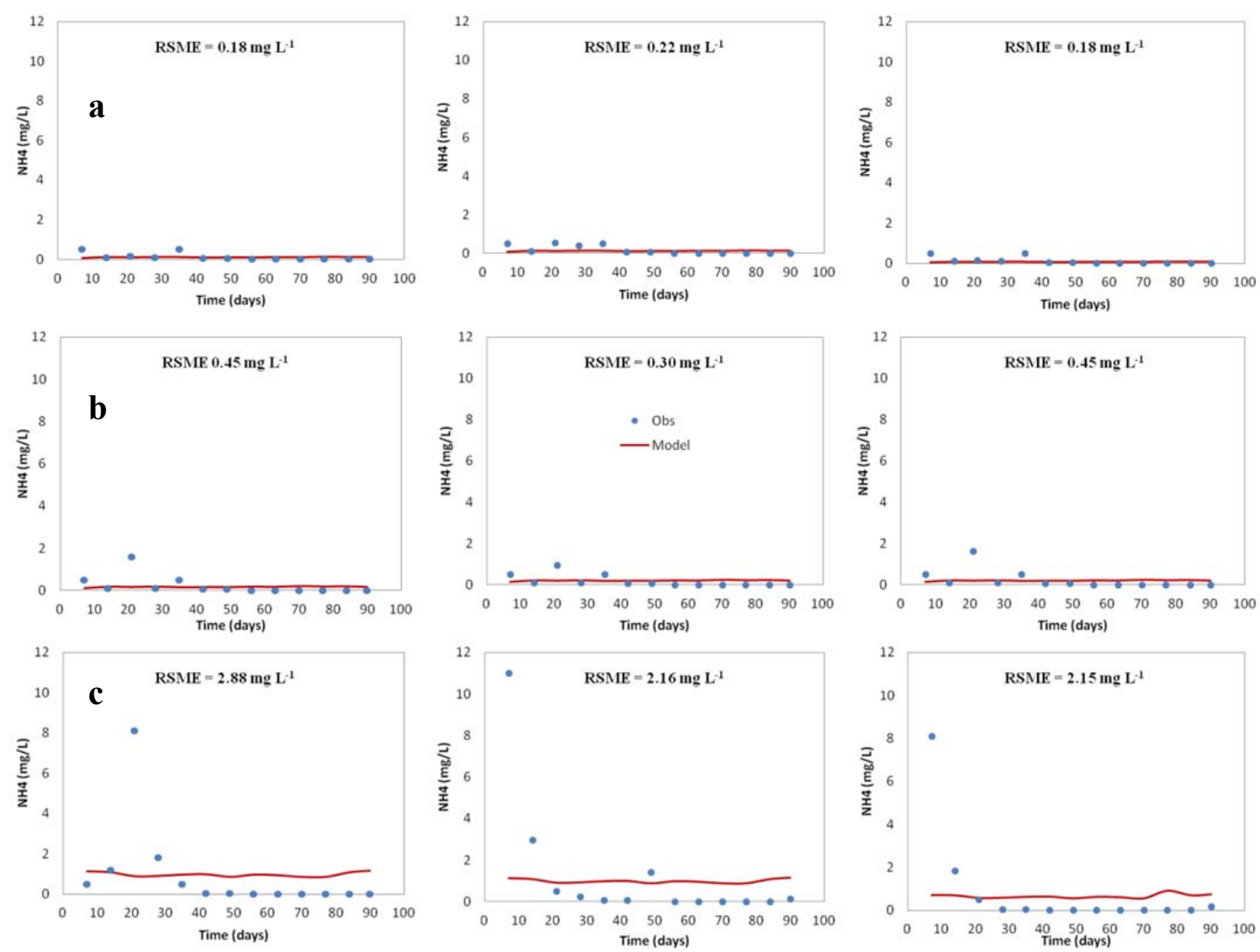
Figure 3. 6 Predicted and measured $\mathrm{NO}_{3}{ }^{-}$concentrations for (a) PSND, (b), GEO and (c) P\&S.
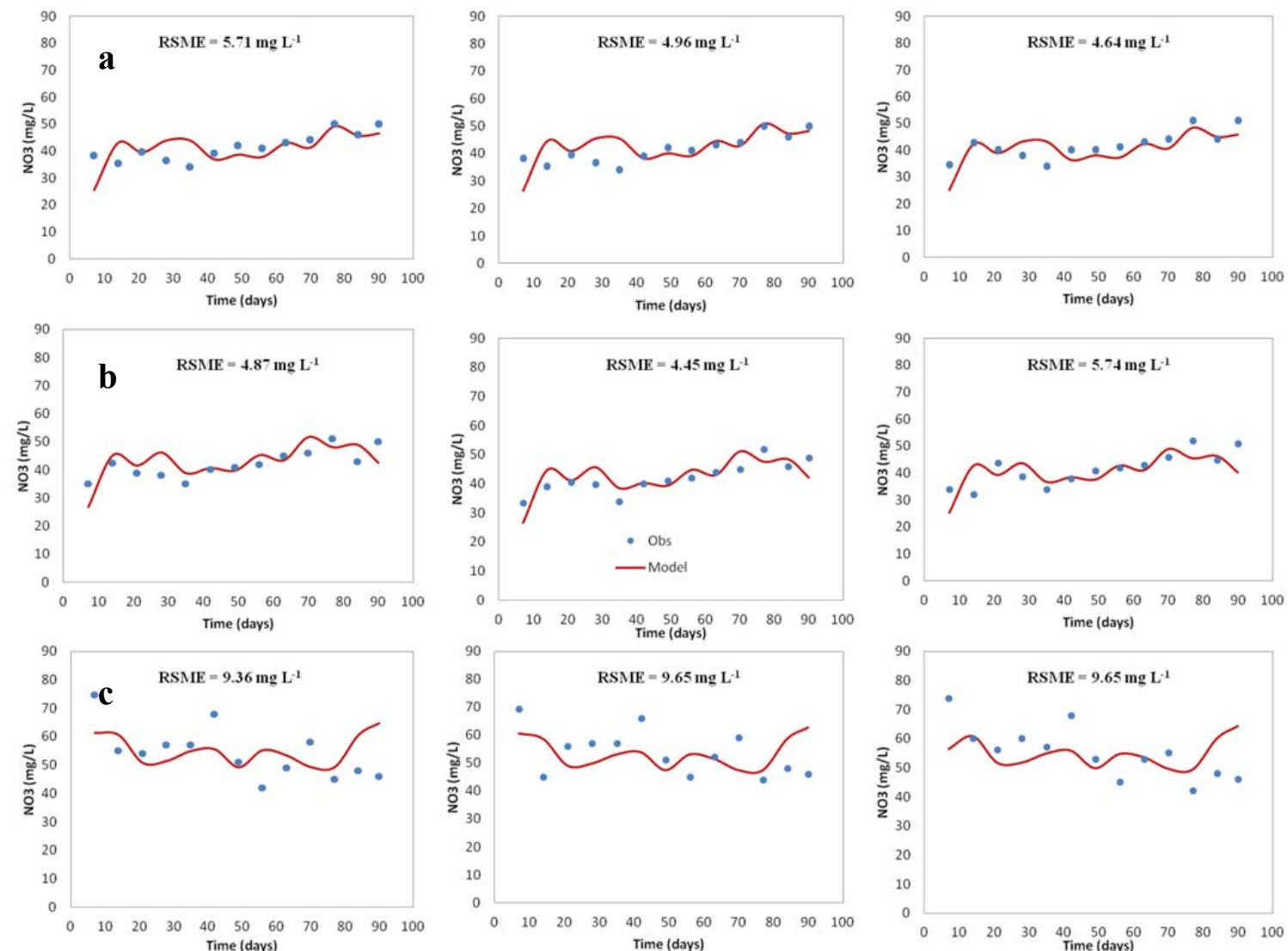


\section{SUPLEMENTAL INFORMATION}

Table S1. Select morphological, physical and chemical properties of the soil used in drainfield mesocosms. Values for physical and chemical properties are means $(n=7) \pm$ s.d. Measurements of $\mathrm{pH}$, electrical conductance $(\mathrm{EC})$ and cation exchange capacity (CEC) were made on composite samples. Cooper et al. (2015).

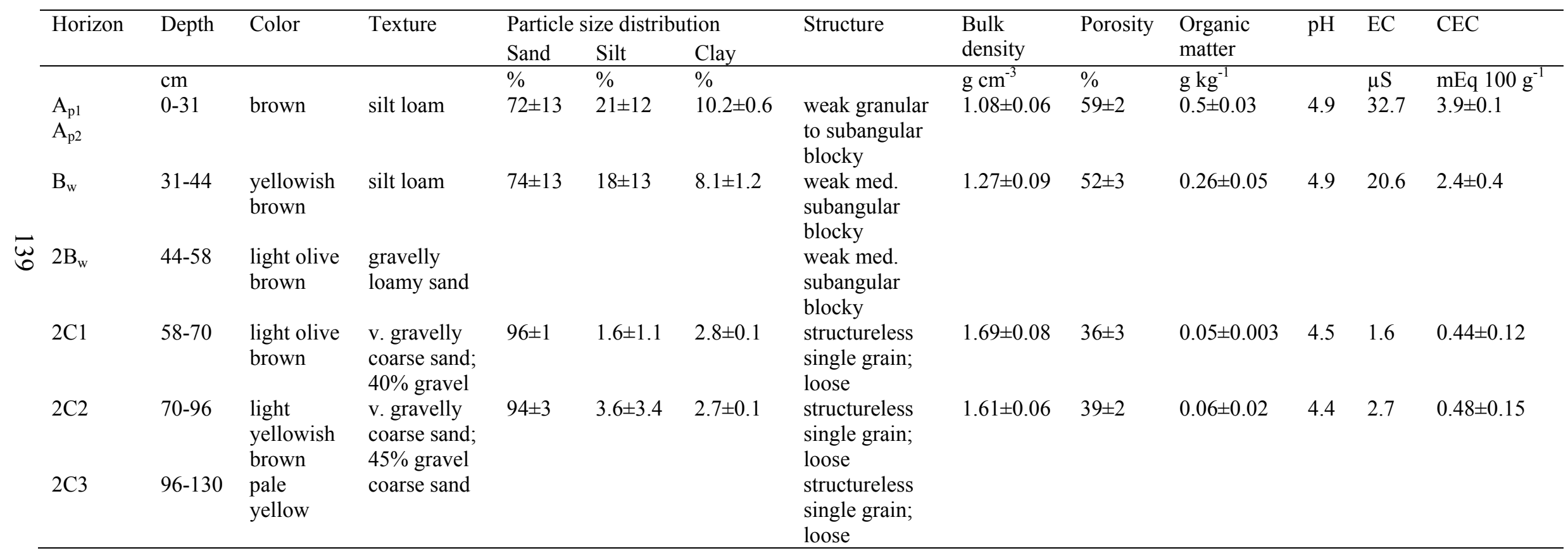


Table S2. Characteristics of septic tank effluent (STE) and sand filter effluent (SFE) used in our study ( $\mathrm{n}=26$ - 49). Cooper et al. (2015).

\begin{tabular}{|c|c|c|c|c|}
\hline \multirow[t]{2}{*}{ Property } & \multicolumn{2}{|l|}{ STE } & \multicolumn{2}{|l|}{ SFE } \\
\hline & Median & Range & Median & Range \\
\hline $\mathrm{pH}$ & 6.4 & $5.9-7.3$ & 4.7 & $3.2-6.1$ \\
\hline Dissolved $\mathrm{O}_{2}, \mathrm{mg} \mathrm{L}^{-1}$ & 0.0 & $0.0-0.4$ & 2.5 & $1.2-4.1$ \\
\hline $\mathrm{BOD}_{5}, \mathrm{mg} \mathrm{L}^{-1}$ & 260 & $120-410$ & 19 & $0-80$ \\
\hline Total suspended solids, $\mathrm{mg} \mathrm{L}^{-1}$ & 41 & $18-89$ & 5.0 & $0.0-30$ \\
\hline Electrical conductivity, $\mu \mathrm{S}$ & 770 & $550-920$ & 560 & $360-750$ \\
\hline Fecal coliform bacteria, CFU $100 \mathrm{~mL}^{-1}$ & $3.6 \times 10^{5}$ & $3.0 \times 10^{4}-4.5 \times 10^{6}$ & $3.0 \times 10^{2}$ & $6.0 \times 10^{0}-3.9 \times 10^{4}$ \\
\hline E. coli $\mathrm{CFU} 100 \mathrm{~mL}^{-1}$ & $3.4 \times 10^{5}$ & $1.0 \times 10^{4}-4.4 \times 10^{6}$ & $9.2 \times 10^{1}$ & $0-3.9 \times 10^{4}$ \\
\hline Total $\mathrm{N}, \mathrm{mg} \mathrm{L}^{-1}$ & 72 & $42-95$ & 54 & $29-88$ \\
\hline $\mathrm{NH}_{4}-\mathrm{N}, \mathrm{mg} \mathrm{L}^{-1}$ & 56 & $40-74$ & 14 & $6.0-34$ \\
\hline $\mathrm{NO}_{3}-\mathrm{N}, \mathrm{mg} \mathrm{L}^{-1}$ & 0.1 & $0.0-0.9$ & 30 & $10-58$ \\
\hline Total $\mathrm{P}, \mathrm{mg} \mathrm{L}^{-1}$ & 11 & $6.8-17$ & 7.8 & $3.8-13$ \\
\hline $\mathrm{PO}_{4}-\mathrm{P}, \mathrm{mg} \mathrm{L}^{-1}$ & 6.4 & $3.3-7.9$ & 4.3 & $2.7-6.2$ \\
\hline $\mathrm{SO}_{4}-\mathrm{S}, \mathrm{mg} \mathrm{L}^{-1}$ & 0.8 & $0.2-7.2$ & 9.3 & $4.2-28.8$ \\
\hline Collection temperature, ${ }^{\circ} \mathrm{C}$ & 16 & $5-22$ & 15 & $4-21$ \\
\hline
\end{tabular}




\section{CONCLUSIONS}

This study demonstrates that HYDRUS 2D/3D is a useful tool to predict the fate and transport of microbial and nutrient contaminants under different operational and environmental conditions. The model was able to estimate microbial (bacteria and virus) transport in an onsite wastewater treatment system (OWTS) soil treatment area and attachment-detachment rate coefficients were determined to better understand the transport parameters that control the pathogen concentration in the porous media. The effects of variable environmental conditions on OWTS performance was evaluated in a simulated OWTS trench. For instance, warmer soil temperature and light-to-heavy rainfall events affected the transport of bacteria, which indicates that climate change may influence the OWTS performance, particularly in the soil treatment area. In addition, our model predicted nitrification and denitrification rates and $\mathrm{N}$ losses in a conventional and two advanced OWTS, using measured $\mathrm{NH}_{4}{ }^{+}, \mathrm{NO}_{3}{ }^{-}$and water content data of the soil matrix as calibration parameters. Nevertheless, our model proved that OWTSs are not able to remove nitrate in the STAs. Therefore, the need for additional design modifications in all OWTS types may be necessary to comply with the water quality standards established for nitrate $\left(10 \mathrm{mg} \mathrm{L}^{-1}\right)$. Finally, the modeling approach presented in this study will help to predict the extent of contamination and their spatial distribution which aides in identifying non-point sources, and to establish total minimum daily loads (TMDLs). 


\section{BIBLIOGRAPHY}

1. Adams MH. Bacteriophages. Bacteriophages. 1959. p. 592.

2. Addiscott TM, Wagenet R. Concepts of solute leaching in soils : a review of modelling approaches. J Soil Sci. 1985;36(Table I):411-24.

3. Agency USEP. Onsite $\mathrm{W} w$ ater $\mathrm{T}$ reatment astew Wastewater aste Treatment Systems Manual. Environ Prot. 2002;(February):1-367.

4. Anderson, D.L., Otis, R.J., McNeillie, J.I., Apfel RA. In-situ lysimeter investigation of pollutant attenuation in the vadose zone of a fine sand. Proceedings of the Seventh International Symposium on Individual and Smaill Community Sewage Systems. St. Joseph, MI: ASAE; 1994. p. 209-18.

5. APHA, AWWA, WEF. Standard Methods for the Examination of Water and Wastewater 20th edition. Public Health. 1999.

6. APHA, AWWA, WEF. Standard Methods for the Examination of Water and Wastewater 20th edition. Public Health. 1999.

7. Ausland G, Stevik TK, Hanssen JF, Køhler JC, Jenssen PD. Intermittent filtration of wastewater--removal of fecal coliforms and fecal streptococci. Water Res. 2002;36:3507-16.

8. Azadpour-Keeley AB. Movement and longevity of viruses in the subsurface. In: Ground Water Issue EPA/540/S-03/500. Cincinnati, OH: United States Environmental Protection Agency - Nat. Risk Management Research Laboratory. Cincinnati, OH; 2003.

9. Beach DNH. Infiltration of wastewater in sand columns. MS Thesis, Colorado School of Mines, Golden, CO; 2001.

10. Beal CD, Gardner EA, Kirchhof G, Menzies NW. Long-term flow rates and biomat zone hydrology in soil columns receiving septic tank effluent. Water Res. 2006;40:2327-38.

11. Beal CD, Gardner EA, Menzies NW. Process, performance, and pollution potential: A review of septic tank-soil absorption systems. Australian Journal of Soil Research. 2005. p. 781-802.

12. Beggs RA, Hills DJ, Tchobanoglous G, Hopmans JW. Fate of nitrogen for subsurface drip dispersal of effluent from small wastewater systems. J Contam Hydrol. 2011;126(1-2):19-28. 
13. Beggs, R.A., G. Tchobanoglous, Hills, D., Crites RW. Modeling subsurface drip application of on-site wastewater treatment system effluent. tenth National Symposium on individual and small community sewage treatment. Sacramento, CA; 2004.

14. Bhattacharjee S, Ryan JN, Elimelech M. Virus transport in physically and geochemically heterogeneous subsurface porous media. J Contam Hydrol. 2002;57:161-87.

15. Birkham TK, Hendry MJ, Wassenaar LI, Mendoza CA. A transient model of vadose zone reaction rates using oxygen isotopes and carbon dioxide. Vadose Zo J. 2007;6:67-76.

16. Bitton G. Wastewater Microbiology: Fourth Edition. Wastewater Microbiology: Fourth Edition. 2010.

17. Bollmann A, Conrad R. Acetylene blockage technique leads to underestimation of denitrificat 1 on rates in oxic soils due to scavenging of intermediate nitric oxide. Soil Biol Biochem. 1997;29(7):1067-77.

18. Bradshaw JK, Radcliffe DE, Šimůnek J, Wunsch A, McCray JE. Nitrogen Fate and Transport in a Conventional Onsite Wastewater Treatment System Installed in a Clay Soil: A Nitrogen Chain Model. Vadose Zo J. 2013 Aug;12(3):1-20.

19. Brady NC, Weil RR. The nature and properties of soils. Macmillan Publishing CoNew York. 2002. 960 p.

20. Brandes, M., Chowhdry, N.A., Cheng WW. Experimental study on removal of pollutants from domestic sewage by underdrained soil filters. national home sewage disposal symposium. Chicago, IL; 1974.

21. Brevé MA. Modeling the movement and fate of nitrogen in artificially drained soils. Ph.D. diss., North Carolina State University, Raleigh, N.C.; 1994.

22. Brooks, R. H., Corey AT. Properties of porous media affecting fluid flow. J Irrig Drain Div. 1966;2(1992):61-90.

23. Burks, D.B. and Minnis MM. Onsite Wastewater Treatment Systems. Madison, WI: Hogart House, Ltd.; 1994. 248 p.

24. Burt R. Soil Survey Laboratory Methods Manual. Soil Surv Investig Rep. 2004;42:735.

25. Cannavo P, Richaume A, Lafolie F. Fate of nitrogen and carbon in the vadose zone: In situ and laboratory measurements of seasonal variations in aerobic respiratory and denitrifying activities. Soil Biol Biochem. 2004;36:463-78. 
26. Canter, L. W., \& Knox RC. Septic tank system effects on ground water quality. Lewis Publishers, Inc; 1985.

27. Carlile BL. Use of shallow, low pressure injection systems in large and small installations. In NI McClelland (ed) Proceedings of the 6th National Conference on Individual Onsite Wastewater Systems. Ann Harbor, MI: National Sanitation Foundation; 1980. p. 371-85.

28. Cey EE, Rudolph DL, Passmore J. Influence of macroporosity on preferential solute and colloid transport in unsaturated field soils. J Contam Hydrol. 2009;107:45-57.

29. Chao WL, Feng RL. Survival of genetically engineered Escherichia coli in natural soil and river water. J Appl Bacteriol. 1990;68:319-25.

30. Chu, Y., Jin, Y., Baumann, T., \& Yates M. Effect of soil properties on saturated and unsaturated virus transport through columns. J Environ Qual. 2003;32(6):2017-25.

31. Cooper JA, Loomis GW, Kalen D V, Amador JA. Evaluation of Water Quality Functions of Conventional and Advanced Soil-Based Onsite Wastewater Treatment Systems. J Environ Qual. 2015 Feb;

32. Cote CM, Bristow KL, Charlesworth PB, Cook FJ, Thorburn PJ. Analysis of soil wetting and solute transport in subsurface trickle irrigation. Irrig Sci. 2003 Nov $1 ; 22(3-4): 143-56$.

33. Crites RW. Micropollutant removal in rapid infiltration. Artificial Recharge of Groundwater. Butterworth Publishers; 1985.

34. Doane T a, Horwath WR. Spectrophotometric Determination of Nitrate with a Single Reagent. Anal Lett. 2003;36:2713-22.

35. Doran, J. W., Mielke, L.N., Stamatiadis S. Microbial activity and N cycling as regulated by soil water-filled pore space. Tillage and traffic in crop production Proc 11th Int Soil Tillage Res Organization. 1988. p. 49-54.

36. Dowd SE, Pillai SD, Wang S, Corapcioglu MY. Delineating the specific influence of virus isoelectric point and size on virus adsorption and transport through sandy soils. Appl Environ Microbiol. 1998;64:405-10.

37. Faulkner, B., Lyon, W., Khan, F., \& Chattopadhyay S. Predicting Attenuation of Viruses During Percolation in Soils: 1. Probabilistic Model. EPA/600/R-02/051a. Cincinnati, OH; 2002. 
38. Faulkner BR, Lyon WG, Khan FA, Chattopadhyay S. Modeling leaching of viruses by the Monte Carlo method. Water Research. 2003. p. 4719-29.

39. Faulkner BR, Lyon WG, Khan FA, Chattopadhyay S. Modeling leaching of viruses by the Monte Carlo method. Water Res. 2003;37:4719-29.

40. Feighery, J., Mailloux, B. J., Ferguson, A. S., Ahmed, K. M., Geen, A., \& Culligan PJ. Transport of E. coli in aquifer sediments of Bangladesh: Implications for widespread microbial contamination of groundwater. Water Resour Res. 49:3897911.

41. Fischer EA. Nutrient Transformation and Fate During Intermittent Sand Filtration of Wastewater. MS Thesis, Colorado School of Mines, Golden, CO.; 1999.

42. Foppen JWA, Schijven JF. Evaluation of data from the literature on the transport and survival of Escherichia coli and thermotolerant coliforms in aquifers under saturated conditions. Water Res. 2006;40:401-26.

43. Frimpter MH, Donohue JJ, Rapacz M V. Mass-balance model for predicting nitrate in ground water. J New Engl Water Work Assoc. 1990;104(4):219-32.

44. Gargiulo G, Bradford SA, Simunek J, Ustohal P, Vereecken H, Klumpp E. Bacteria transport and deposition under unsaturated flow conditions: The role of water content and bacteria surface hydrophobicity. Vadose Zo J. 2008;7:406-19.

45. Gelhar LW, Welty C, Rehfeldt KR. A critical review of data on field-scale dispersion in aquifers. Water Resour Res. 1992 Jul 9;28(7):1955-74.

46. Gerba, C. P. \& CW. Fate of wastewater bacteria and viruses in soil. J Irrig Drain Div. 1975;101(IR3).

47. Gerba, C. P., \& Goyal SM. Pathogen removal from wastewater during groundwater recharge. Artifical Recharge of Groundwater. Butterworth Publishers; 1985.

48. Gerba, C.P.; Goyal SM. Pathogen Removal from Wastewater During Groundwater Recharge. Artifical Recharge of Groundwater. Waltham, MA: Butterworth Publishers; 1985. p. 784.

49. Geza M, Lowe K, McCray J. STUMOD - a Tool for Predicting Fate and Transport of Nitrogen in Soil Treatment Units. Environ Model Assess. Springer International Publishing; 2014;19(3):243-56.

50. Giblin AE, Gaines AG. Nitrogen inputs to a marine embayment: the importance of groundwater. Biogeochemistry. 1999 Jun 1;10(3):309-28. 
51. Gill LW, O’Súlleabháin C, Misstear BDR, Johnston PJ. The Treatment Performance of Different Subsoils in Ireland Receiving On-Site Wastewater Effluent. J Environ Qual. 2007;(6):1843-55.

52. Gill L, O’Luanaigh N, Johnston P, Misstear BDR, O’Suilleabhain C. Nutrient loading on subsoils from on-site wastewater effluent, comparing septic tank and secondary treatment systems. Water Res. 2009;43(10):2739-49.

53. Goyal SM, Gerba CP. Comparative adsorption of human enteroviruses, simian rotavirus, and selected bacteriophages to soils. Appl Environ Microbiol. 1979;38:241-7.

54. Goyal, S., \& Gerba C. Comparative Adsorption of Human Enteroviruses, Simian Rotavirus, and Selected Bacteriophages to Soils. Appl Environ Microbiol. 1979;32(2):241-7.

55. Grant RF. Mathematical modelling of nitrous oxide evolution during nitrification. Soil Biol Biochem. 1995;27(9):1117-25.

56. Han J, Jin Y, Willson CS. Virus retention and transport in chemically heterogeneous porous media under saturated and unsaturated flow conditions. Environ Sci Technol. 2006;40:1547-55.

57. Harden HS, Roeder E, Hooks M, Chanton JP. Evaluation of onsite sewage treatment and disposal systems in shallow karst terrain. Water Res. 2008 May;42(10-11):2585-97.

58. Hargett DL. Performance assessment of low pressure pipe wastewater injection systems. 4th National Symposium on Individual and Small Community Sewage Systems. St. Thomas, MI; 1985. p. 131-43.

59. Harvey, R. W., Kinner, N. E., MacDonald, D., Metge, E. W., \& Bunn A. Role of physical heterogeneity in the interpretation of small scale laboratory and field observations of bacteria, microbial-sized microsphere, and bromide transport through aquifer sediments. Water Resour Res. 1993;29(8):2713-21.

60. Hassan G, Reneau RB, Hagedorn C, Jantrania AR. Modeling Effluent Distribution and Nitrate Transport through an On-Site Wastewater System. 2008 Sep;1937-48.

61. Hassan G, Reneau RB, Hagedorn C, Jantrania AR. Modeling effluent distribution and nitrate transport through an on-site wastewater system. J Environ Qual. 2008;37(5):1937-48.

62. Hassanizadeh SM, Torkzaban S, de Bruin HAM, Schijven JF, de Roda Husman AM. Virus Transport in Saturated and Unsaturated Sand Columns. Vadose Zo J. 2006;5:877-85. 
63. Heatwole KK, McCray JE. Modeling potential vadose-zone transport of nitrogen from onsite wastewater systems at the development scale. J Contam Hydrol. 2007;91(1-2):184-201.

64. Holden SA. The effectiveness of shallow-narrow drainfields to treat domestic wastewater. University of Rhode Island; 2004.

65. Holden, S.A., Stolt, M.H., Loomis, G.W., Gold AJ. Seasonal variation in nitrogen leaching from shallow narrow drainfields. In: Mankin, editor. Proceedings of the Tenth International Symposium on Individual and Small Community Sewage Systems. St. Joseph, MI: ASAE; 2004. p. 432-40.

66. Jarvis NJ. A review of non-equilibrium water flow and solute transport in soil macropores: principles, controlling factors and consequences for water quality. Eur J Soil Sci. 2007;58:523-46.

67. Jiang S, Pang L, Buchan GD, Simůnek J, Noonan MJ, Close ME. Modeling water flow and bacterial transport in undisturbed lysimeters under irrigations of dairy shed effluent and water using HYDRUS-1D. Water Res. 2010;44:1050-61.

68. Jin, Y., Chu, Y., \& Li Y. Virus removal and transport in saturated and unsaturated sand columns. J Contam Hydrol. 2000;43:111-28.

69. Kosugi K. Lognormal distribution model for unsaturated soil hydraulic properties. Water Resour Res. 1996;32(9):2697-703.

70. Kristiansen R. Sand Filter Trenches for Purification of Septic Tank Effluent: I. The Clogging Mechanism and Soil Physical Environment. J Environ Qual. 1981;10(3):353-7.

71. Lance JC, Gerba CP. Virus movement in soil during saturated and unsaturated flow. Appl Environ Microbiol. 1984;47:335-7.

72. Lapen DR, Price JS, Gilbert R. Soil water storage dynamics in peatlands with shallow water tables. Canadian Journal of Soil Science. 2000. p. 43-52.

73. Lepore, B., \& Barak P. A colorimetric microwell method for determining bromide concentrations. Soil Sci Soc Am J. 2009;73:1130-6.

74. Lide DR. CRC Handbook of Chemistry and Physics, 94th Edition, 2013-2014. Handbook of Chemistry and Physics. 2013. 2616 p.

75. Linn DM, Doran JW. Effect of Water-Filled Pore Space on Carbon Dioxide and Nitrous Oxide Production in Tilled and Nontilled Soils1. Soil Science Society of America Journal. 1984. p. 1267. 
76. Loomis GW, Dow DB, Stolt MH, Green LT, Gold AJ. Evaluation of innovative onsite wastewater treatment systems in the green hill pond watershed, Rhode Island - A NODP II project update. On-Site Wastewater Treat Proc. 2001;506-15.

77. Malhi SS, McGill WB. Nitrification in three Alberta soils: effects of temperature, moisture and substrate concentration. Soil Biol Biochem. 1982;14(4):393-9.

78. McCray, J., M. Geza, K. Lowe, T. Boving, D. Radcliffe, M. Tucholke, A. Wunsch, S. Roberts, J. Amador, J. Atoyan, J. Drewes, D. Kalen GL. Quantitative Tools to Determine the Expected Performance of Wastewater Soil Treatment Units: Guidance Manual. 2010.

79. McCray JE, Kirkland SL, Siegrist RL, Thyne GD. Model parameters for simulating fate and transport of on-site wastewater nutrients. Ground Water. 2005. p. $628-39$.

80. McCray JE, Kirkland SL, Siegrist RL, Thyne GD. Model parameters for simulating fate and transport of on-site wastewater nutrients. Ground Water. 2005. p. $628-39$.

81. McCray JE, Siegrist RL, Beach DNH, Lowe KS. Temporal changes in hydraulic conductivity of sand porous media biofilters during wastewater infiltration due to biomat formation. Journal of Hydrology. 2005. p. 230-43.

82. McGechan MB, Vinten AJA. Simulation of transport through soil of E-coli derived from livestock slurry using the MACRO model. Soil Use Manag. 2003;19(4):321-30.

83. Millington RJ, Quirk JP. Transport in porous media. Trans 7th int Congr Soil Sci. 1960;1:97-106.

84. Moore SK, Garvin RT, James E. Nucleotide sequence of the argF regulatory region of Escherichia coli K-12. Gene. 1981;16:119-32.

85. Morales I, Atoyan JA, Amador JA, Boving T. Transport of pathogen surrogates in soil treatment units: Numerical modeling. Water (Switzerland). 2014;6(4):818-38.

86. Mualem Y. A new model for predicting the hydraulic conductivity of unsaturated porous media. Water Resour Res. 1976;12(3):513-22.

87. Pang, L., McLeod, M., Aislabie, J., Šimůnek, Close, M., \& Hector R. Modeling Transport of Microbes in Ten Undisturbed Soils under Effluent Irrigation. Vadose Zo J. 2008;7:97-111. 
88. Pang L, Close M, Goltz M, Sinton L, Davies H, Hall C, et al. Estimation of septic tank setback distances based on transport of E. coli and F-RNA phages. Environ Int. 2004;29:907-21.

89. Pang L, Šimůnek J. Evaluation of bacteria-facilitated cadmium transport in gravel columns using the HYDRUS colloid-facilitated solute transport model. Water Resour Res. 2006;42.

90. Park NS, Blanford TN, Huyakorn PS. VIRALT: A model for simulating viral transport in groundwater, Documentation and user's guide, Version 2.1. HydroGeoLogic, Inc.: Herndon, VA; 1992.

91. Park, N.-S., Blandford, T.N., Wu, Y.-S., Huyakorn PS. CANVAS: a composite analytical-numerical model for viral and solute transport simulation. Documentation and User's Guide, , Version 1.0. HydroGeoLogic, Herndon, VA; 1993.

92. Pieper a P, Ryan JN, Harvey RW, Amy GL, Illangasekare TH, Metge DW. Transport and recovery of bacteriophage PRD1 in a sand and gravel aquifer: Effect of sewage-derived organic matter. Environ Sci Technol. 1997;31:1163-70.

93. Pinheiro LB, Gibbs MD, Vesey G, Smith JJ, Bergquist PL. Fluorescent reference strains of bacteria by chromosomal integration of a modified green fluorescent protein gene. Appl Microbiol Biotechnol. 2008;77:1287-95.

94. Pivetz BE, Steenhuis TS. Soil Matrix and Macropore Biodegradation of 2,4-D. J Environ Qual. 1995;24:564.

95. Pivetz BE, Alexander M, Kelsey JW, Steenhuis TS. A Procedure to Calculate Biodegradation during Preferential Flow through Heterogeneous Soil Columns. Soil Sci Soc Am J. 1996;60:381.

96. Poeter EP, Hill MC. UCODE, a computer code for universal inverse modeling. Comput Geosci. 1999;25(4):457-62.

97. Potts, D., Gorres, J., Nicosia, E., \& Amador J. Effects of Aeration on Water Quality from Septic System Leachfields. J Environ Qual. 33(1828-1838).

98. Powelson, D. K. \& JRS. Virus Transport and Survival in Saturated and Unsaturated Flow through Soil Columns. J Env Qual. 1990;19(3):396-401.

99. Powelson DK, Gerba CP. Virus removal from sewage effluents during saturated and unsaturated flow through soil columns. Water Res. 1994;28(10):2175-81.

100. Powelson DK, Gerba CP. Virus removal from sewage effluents during saturated and unsaturated flow through soil columns. Water Res. 1994;28:2175-81. 
101. Powelson, David K.; Mills AL. Transport of Escherichia coli in Sand Columns with Constant and Changing Water Contents. J Environ Qual. 2001;30:238-45.

102. Prescott LM, Klein DA, Harley JP. Microbiology. Microbiology. 2002.

103. R.J. Miles, Robert Rubin and LW. Fecal Coliform Distribution Under Pressure Dosed Onsite Wastewater Systems. Elev Individ Small Community Sew Syst Conf Proceedings, (20-24 Oct 2007, Warwick, Rhode Island, USA). 2007;

104. Radcliffe DE, Bradshaw JK. Model Test of Proposed Loading Rates for Onsite Wastewater Treatment Systems. 2014;(6):97-107.

105. Rajagopalan R, Tien C. Trajectory analysis of deep-bed filtration with the spherein-cell porous media model. AIChE J. American Institute of Chemical Engineers; 1976;22(3):523-33.

106. Reneau RB, Hagedorn C, Degen MJ. Fate and Transport of Biological and Inorganic Contaminants from On-Site Disposal of Domestic Wastewater. J Environ Qual. 1989;135-44.

107. Safadoust A, Mosaddeghi MR, Heydari A, Gharabaghi B, Mahboubi AA, Voroney $\mathrm{P}$, et al. Effect of regenerated soil structure on unsaturated transport of Escherichia coli and bromide. J Hydrol. 2012;430-431:80-90.

108. Schaap MG, Leij FJ, Van Genuchten MT. Rosetta: A computer program for estimating soil hydraulic parameters with hierarchical pedotransfer functions. J Hydrol. 2001;251(3-4):163-76.

109. Schjønning P, Thomsen IK, Moldrup P, Christensen BT. Linking Soil Microbial Activity to Water- and Air-Phase Contents and Diffusivities. Soil Science Society of America Journal. 2003. p. 156.

110. Schoenau, J., \& Karamanos R. Sodium bicarbonate-extractable P, K, and N. In Carter ed. Soil sampling and methods of analysis. Can Soc Soil Sci. 1993;51-8.

111. Šejna M, van Genuchten MT, Šimůnek J. Development and Applications of the HYDRUS and STANMOD Software Packages and Related Codes. Vadose Zone Journal. 2008. p. 587.

112. Selim HM, Schulin R, Flühler H. Transport and Ion Exchange of Calcium and Magnesium in an Aggregated Soil. Soil Sci Soc Am J. 1987;51(4):876.

113. Sexstone AJ, Revsbech NP, Parkin TB, Tiedje JM. Direct Measurement of Oxygen Profiles and Denitrification Rates in Soil Aggregates1. Soil Science Society of America Journal. 1985. p. 645. 
114. Shelton DR, Pachepsky YA, Sadeghi AM, Stout WL, Karns JS, Gburek WJ. Release Rates of Manure-Borne Coliform Bacteria from Data on Leaching through Stony Soil. Vadose Zone Journal. 2003. p. 34.

115. Shuval HI, Gruener N. Proceedings of the Conference on Nitrogen As a Water Pollutant. Proceedings of the Conference on Nitrogen As a Water Pollutant. 2013. 183-193 p.

116. Siegrist, R.L., Tyler, E.J., Jenssen PD. Design and Performance of Onsite Wastewater Soil Absorption Systems. National Research Needs Conference: RiskBased Decision Making for Onsite Wastewater Treatment. Palo Alto, CA: EPRI Report; 2001.

117. Šimůnek, J.van Genuchten MT. Numerical model for simulating multiple solute transport in variably-saturated soils. In: Wrobel, L., Latinopoulos P, editor. Water Pollution III: Modelling, Measurement, and Prediction. Southampton, UK: Computation Mechanics Publication, Ashurst Lodge, Ashurst; 1995. p. 21-30.

118. Simunek J, Genuchten M Van, Sejna M. The HYDRUS software package for simulating the two-and three-dimensional movement of water, heat, and multiple solutes in variably-saturated media. Technical manual. 2012.

119. Simunek J, He C, Pang L, Bradford SA. Colloid-Facilitated Solute Transport in Variably Saturated Porous Media: Numerical Model and Experimental Verification. Vadose Zo J. 2006;5:1035-47.

120. Šimůnek J, van Genuchten MT, Šejna M. Development and Applications of the HYDRUS and STANMOD Software Packages and Related Codes. Vadose Zone Journal. 2008. p. 587.

121. Sobsey MD, Dean CH, Knuckles ME, Wagner RA. Interactions and survival of enteric viruses in soil materials. Appl Environ Microbiol. 1980;40:92-101.

122. Sobsey, M. D., \& Shields PA. Survival and transport of viruses in soils. Human viruses in sediments, sludges, and soils. Boca Raton, FL: CRC Press; 1987. p. $155-77$.

123. Standley L., Swartz C, Rudel RA, Attfield KR, J. C, Erickson M, et al. Wastewater-contaminated Groundwater as a Source Of Endogenous Hormones and Pharmaceuticals to Surface Water Ecosystems. 2008;

124. Stevik TK, Aa K, Ausland G, Hanssen JF. Retention and removal of pathogenic bacteria in wastewater percolating through porous media: A review. Water Research. 2004. p. 1355-67. 
125. Stewart, L.W. and Reneau RB. Shallowly placed, low pressure distribution system to treat domestic wastewater in soil with fluctuating high water tables. J Environ Qual. 1988;(17):499-504.

126. Swartz CH, Reddy S, Benotti MJ, Yin H, Barber LB, Brownawell BJ, et al. Steroid Estrogens, Nonylphenol Ethoxylate Metabolites, and Other Wastewater Contaminants in Groundwater Affected by a Residential Septic System on Cape Cod, MA. Environ Sci Technol. American Chemical Society; 2006 Aug 18;40(16):4894-902.

127. Toride N, Leij FJ, Van Genuchten MT. The CXTFIT code for estimating transport parameters from laboratory or field tracer experiments. Res Rep. 1995; Research $\mathrm{R}: 1-138$.

128. Tucholke, M. B., McCray, J. E., Thyne, G. D., Waskom RM. Variability in denitrification rates: literature review and analysis. National Onsite Wastewater Recycling Association 16th Annual Technical Education \& Exposition Conference. Baltimore, MD: NOWRA, Santa Cruz, CA; 2007.

129. Turco RF. Detection and enumeration of coliform bacteria in soil. Methods of soil analysis: Microbial and biochemical properties. Madison, WI; 1994. p. 145-59.

130. Tyler, E.J., Laak, R., McCoy, E., Sandhu SS. The Soil as a treatment system. Proceedings of the Second National Home Sewage Treatment Symposium. St. Joseph, MI: ASAE; 1977. p. 5-77.

131. U.S. Environmental Protection Agency. Watershed Assessment, Tracking \& Environmental Results [Internet]. 2015 [cited 2003 May 20]. Available from: http://ofmpub.epa.gov/waters10/attains_nation_cy.control

132. U.S. Environmental Protection Agency. Onsite Wastewater Treatment Systems Manual. Environ Prot. 2002;1-367.

133. Unc AA, Goss MJ. Movement of faecal bacteria through the vadose zone. Water Air Soil Pollut. 2003;149:327-37.

134. US Environmental Protection Agency. Wadeable Streams Assessment: A Collaborative Survey of the Nation's Streams. Office of Water, US Environmental Protection Agency, Washington DC. 2006.

135. USEPA. Guidance for federal land management in the Chesapeake Bay watershed. EPA Rep. 841-R-10-002. 2010.

136. Valiela I, Bowen JL, Kroeger KD. Assessment of models for estimation of landderived nitrogen loads to shallow estuaries. Appl Geochemistry. 2002;17(7):93553. 
137. van Genuchten MT. A Closed-form Equation for Prediccting Hydraulic Conductivity of Unsaturated Soils. Soil Sci Soc Am J. 1980;44(5):892-8.

138. van Genuchten MT. A Closed-form Equation for Prediccting Hydraulic Conductivity of Unsaturated Soils. Soil Sci Soc Am J. 1980;44(5):892-8.

139. van Genuchten MT. A Closed-form Equation for Predicting the Hydraulic Conductivity of Unsaturated Soils1. Soil Sci Soc Am J. 1980;44:892-8.

140. van Genuchten MT, Wagenet RJ. Two-Site/Two-Region Models for Pesticide Transport and Degradation: Theoretical Development and Analytical Solutions. Soil Sci Soc Am J. 1989;53(5):1303.

141. Vanderborght J, Vereecken H. Review of Dispersivities for Transport Modeling in Soils. Vadose Zo J. 2007 Feb 1;6(1):29.

142. Wang Y, Bradford S a., Šimůnek J. Transport and fate of microorganisms in soils with preferential flow under different solution chemistry conditions. Water Resour Res. 2013;49:2424-36.

143. Ward MH, Mark SD, Cantor KP, Weisenburger DD, Correa-Villaseñor A, Zahm SH. Drinking water nitrate and the risk of non-Hodgkin's lymphoma. Epidemiology. 1996;7(5):465-71.

144. Weast R. CRC handbook of chemistry and physics : a ready-reference book of chemical and physical data. Boca Raton Fla.: CRC Press; 1985.

145. Weintraub LHZ, Chen CW, Goldstein RA, Siegrist RL. WARMF: A watershed modeling tool for onsite wastewater systems. Proceedings of the 10th National Symposium on Individual and Small Community Sewage Systems, ASAE. 2004. p. $636-46$.

146. Weiskel PK, Howes BL. Differential Transport of Sewage-Derived Nitrogen and Phosphorus Through a Coastal Watershed. Env Sci Technol. 1992;26(2):352-60.

147. Yao K, Habibian MT, O'Melia CR. Water and Waste Water Filtration: Concepts and Applications. Environ Sci Technol. 1971;5:1105-12.

148. Yates M V., Ouyang Y. VIRTUS, a model of virus transport in unsaturated soils. Appl Environ Microbiol. 1992;58(5):1609-16.

149. Yeh GT, Cheng JR, Short TE. 3DFATMIC: User's Manual of a ThreeDimensional Model of Subsurface Flow, Fat and Transport of Microbes and Chemicals. EPA/600/R-97-053. National Risk Management Research Laboratory, USEPA, Ada, OK 74820; 1997. 
150. Youssef MA, Youssef MA, Skaggs RW, Skaggs RW, Chescheir GM, Chescheir GM, et al. Drainmod - n ii. Society. 2005;48(2):611-26.

151. Zhang H, Nordin NA, Olson MS. Evaluating the effects of variable water chemistry on bacterial transport during infiltration. J Contam Hydrol. 2013;150:54-64.

152. Zhang, Q., Hassanizadeh, S. M., Raoof, A., Genuchten, M. v., \& Roels SM. Modeling Virus Transport and Remobilization during Transient Partially Saturated Flow. Vadose Zo J. 2011;11(2).

153. Zhao L, Ju X, Li B, Hu K, Wang H, Wei Y. Simulation of bromide and nitrate leaching under heavy rainfall and high-intensity irrigation rates in North China Plain. Agricultural Water Management. 2010. p. 1646-54. 